UNIVERSIDADE DE SÃO PAULO

FACULDADE DE EDUCAÇÃO

MARINEILA APARECIDA MARQUES

PROJETO POLÍTICO PEDAGÓGICO DAS PRISÕES -

PPPprisões

SÃO PAULO-SP

2021 
MARINEILA APARECIDA MARQUES

\title{
PROJETO POLÍTICO PEDAGÓGICO DAS PRISÕES -
}

\author{
PPPprisões
}

Dissertação apresentada ao Programa de Pósgraduação em Educação da Faculdade de Educação da Universidade de São Paulo, como pré-requisito necessário para a obtenção do título de Mestre em Educação.

Área de concentração: Estado, sociedade e educação

Orientador: Dr. Roberto da Silva

\section{SÃO PAULO-SP}


Autorizo a reprodução e divulgação total ou parcial desse trabalho, por qualquer meio convencional ou eletrônico, para fins de estudo e pesquisa, desde que citada a fonte.

Catalogação da Publicação

Ficha elaborada pelo Sistema de Geração Automática a partir de dados fornecidos pelo(a) autor(a)

Bibliotecária da FE/USP: Nicolly Soares Leite - CRB-8/8204

M357p Marques, Marineila Aparecida

Projeto politico pedagógico das Prisões

PPPprisões / Marineila Aparecida Marques;

orientador Roberto da Silva. -- São Paulo, 2021.

$145 \mathrm{p}$.

Dissertação (Mestrado - Programa de Pós-Graduação Cultura, Filosofia e História da Educação) Faculdade de Educação, Universidade de São Paulo, 2021 .

1. Educação . 2. Educação em prisões. 3. Educação no cárcere. 4. Projeto político pedagógico. 5. Projeto político pedagógico em prisões. I. da Silva, Roberto, orient. II. Título. 
MARQUES, Marineila Aparecida. PROJETO POLÍTICO PEDAGÓGICO DAS PRISÕES PPP PRISÕES

\author{
Marineila Aparecida Marques
}

Data da aprovação: 10/09/2021

BANCA EXAMINADORA:

Membros titulares

Professor Doutor Roberto da Silva

Faculdade de Educação da Universidade de São Paulo (FEUSP)

Professora Doutora Carolina Bessa Ferreira de Oliveira

Universidade Federal do Sul da Bahia (UFSB)

Professora Doutora Francisca Rodrigues Pini

Universidade Federal de São Paulo (UNIFESP)

\title{
Membro suplente
}

Maria Clara Di Pierro

Faculdade de Educação da Universidade de São Paulo (FEUSP) 
A todos que sobrevivem, resistem e lutam contra as inúmeras injustiças da vida. A minha família, que no cotidiano fundado na dignidade e no amor, fortalece meu caminhar. A Benício e Helo, na esperança de um futuro de amor e justiça. 


\section{AGRADECIMENTOS}

Agradeço com admiração e imenso carinho, meu orientador professor Dr. Roberto da Silva, ser humano excepcional, que caminha derrubando muros, construindo pontes, desafiando estruturas, galgando conquistas e avanços nas garantias de direitos a todas as pessoas.

Agradeço a todos do GEPEPRIVAÇÃO pelo trabalho e dedicação incansáveis, pelos encontros semanais, pelos diálogos, colaboração e participação fundamentais na pesquisa de campo, para a feitura desta dissertação.

Agradeço a Diretoria de Ensino Região Centro Oeste, pela confiança e apoio.

Agradeço a Faculdade de Educação da USP, pelo pioneirismo e ensinamentos.

Agradeço a banca de qualificação desta dissertação, Professoras Dras. Carol Bessa e Francisca Pini, verdadeiramente orientadoras e fraternas.

Agradeço aos amigos e amigas que acolhem e fortalecem a caminhada.

Agradeço a Carolina Bessa e Fernando Lopes, meus melhores encontros nesse campo. Meus parceiros nas lutas, nas batalhas. Meus amigos.

Agradeço as queridas Giane Alvarez e Patrícia Venâncio e ao querido Romualdo Poliseli, por serem instrumentos definitivos nesta caminhada.

Agradeço a Heloísa Aguiar, amiga/irmã, pela paciência, pelo apoio e parceria na vida.

Agradeço minha família, especialmente, o Mili e a Cila, meus pais, por me fortalecerem e me acompanharem por toda a vida, trazendo com eles, todos os dias, exemplos de amor ao próximo, de respeito, tolerância e humildade. 


\section{RESUMO}

MARQUES, Marineila Aparecida. Projeto Político Pedagógico das Prisões - PPP PRISÕES. 2021. 154 f. Dissertação (Mestrado) - Faculdade de Educação. Programa de Pós-graduação em Educação, Universidade de São Paulo, São Paulo 2021.

A presente dissertação discorre sobre oferta de educação para pessoas privadas de liberdade, aqui caracterizada como um processo educativo, onde território prisional e aluno reformula e constrói novas formas de agir e de interagir, de pensar e de se reconhecer como sujeito da sua própria história. Apresenta um processo de estruturação da organização das prisões, pautado por um Projeto Político Pedagógico das prisões (PPPprisões), que exige rupturas, mudanças de paradigmas, sistematização de ações pontuais combinadas a programas consistentes e duradouros, fincados, sobretudo, na humanização e valorização do ser humano sob todos os aspectos, levando em consideração os contextos sociais de cada cidadão, os princípios democráticos, de solidariedade e dignidade do ser humano. Esta dissertação busca contribuir para avanços no que tange a discussão, modelo e implementação das garantias de políticas de reintegração a partir da ampliação do conceito educacional, com a elaboração do que denomino PPPprisões. Construir o PPPprisões requer o entendimento de que as assistências às pessoas privadas de liberdade no interior das prisões, colocando como pilar a assistência educacional, devem encaminhar as respostas: como fazer para que todos os profissionais que trabalham na prisão assumam as tarefas de Educação e de reinserção do preso para o convívio social? Como fazer para que todas as ações e atividades desenvolvidas na prisão durante o cumprimento da sentença se constituam em verdadeiras ações pedagógicas com vistas ao cumprimento da pena com dignidade e que culmine na reintegração social e cidadã?

Palavras-chave: Educação. Educação no cárcere. Prisões. Projeto Político Pedagógico. Projeto Politico Pedagógico das Prisões. PPPprisões. 


\begin{abstract}
MARQUES, Marineila Aparecida. Political Pedagogical Project - PPPprisons. 2021. $154 \mathrm{f}$. Thesis (Master's degree) - School of Education. Dept. in Education, University of São Paulo, São Paulo 2021.

This dissertation discusses the provision of education for people deprived of liberty, characterized here as a dynamic process, seeking for the student to reformulate and build new ways of acting and interacting, of thinking and recognizing themselves as subjects of their own history. It also points out that the process of structuring the education policy in prison, based on a Pedagogical Political Project for Prisons (PPPprisons), requires ruptures, paradigm shifts, systematization of specific actions combined with consistent and long-lasting programs based, above all, on valuing the human being in all aspects, considering the social contexts of each citizen, in democratic principles, solidarity and dignity of the human being. This dissertation seeks to contribute to advances regarding the discussion, model and implementation of the guarantees of resocialization policies from the expansion of the educational concept with the elaboration of what I call PPPprisons. Building PPPprisons requires the understanding that assistance to people deprived of liberty inside prisons, placing educational assistance as a pillar, must provide the answers: how to make all professionals working in the prison assume the tasks of Education and rehabilitation of the prisoner for social life? How to ensure that all actions and activities carried out in prison while serving the sentence constitute true pedagogical actions with a view to serving the sentence with dignity, culminating in social and citizen reintegration?
\end{abstract}

Key words: Education. Education in prison. Prisons. Political Pedagogical Project. Political Pedagogical Project of Prisons. PPP prisons. 


\section{LISTA DE TABELAS}

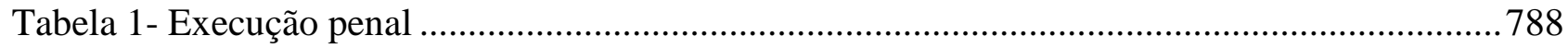

Tabela 2 - Modelos de oferta da educação em prisões no brasil.................................................. 889 


\section{LISTA DE QUADROS}

Quadro 1 - Presos que desenvolvem atividades educacionais por unidade federativa (uf), nos anos de 2017, 2018 e 2019.

Quadro 2- Percentual de presos per capta em atividades educativas por estado 500

Quadro 3 - Estados com ppp específico para prisões... 900

Quadro 4- Histórico de diretrizes para modalidades educacionais 911

Quadro 5 - Projetos desenvolvidos pelas unidades prisionais 1233 


\section{LISTA DE FIGURAS}

Figura 1 - Evolução de pessoas em atividades educacionais

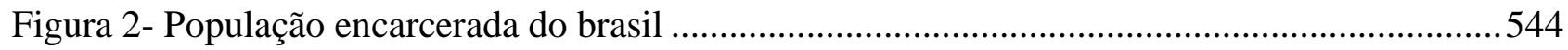

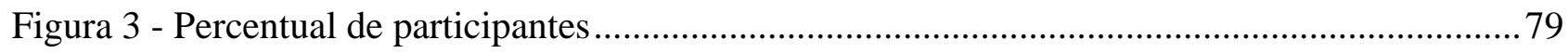

Figura 4 - Organização pppprisões ................................................................................ 1044 


\section{LISTA DE ABREVIATURAS E SIGLAS}

ADE

BNCC

$\mathrm{CIDH}$

$\mathrm{CNCP}$

$\mathrm{CNE} / \mathrm{CEB}$

$\mathrm{CNJ}$

CNPCP

CNSP

CONFITEA

COVID 19

CPPF

DECTO

DEPEN

DHDH

DOE

EJA

ENEM

FEUSP

FUNAP

GEPÊPRIVAÇÃO

INESC

ITTC

LEP

MEC

MJ
Arranjo de Desenvolvimento da Educação

Base Nacional Comum Curricular

Comissão Interamericana de Direitos Humanos

Conselho Nacional de Política Criminal e Penitenciária

Conselho Nacional de Educação/Câmera de Educação Básica

Conselho Nacional de Justiça

Conselho Nacional de Política Criminal e Penitenciária

Conselho Nacional de Segurança Pública

Conferência Internacional de Educação de Adultos

Coronavírus Disease 2019

Centro de Progressão Penitenciária Feminino

Diretoria de Ensino Região Centro Oeste

Departamento Penitenciário Nacional, Coordenação de Educação,

Cultura e do Esporte

Declaração Universal dos Direitos Humanos

Diário Oficial do Estado

Educação de Jovens e adultos

Exame Nacional do Ensino Médio

Faculdade de Educação da Universidade de São Paulo

Fundação Estadual de amparo ao trabalhador preso "Dr. Manoel Artur Pedro Pimentel

Grupo de Estudos e Pesquisas sobre Educação em Regimes de Privação da Liberdade Instituto de Estudos Socioeconômicos

Instituto Terra, Trabalho e Cidadania

Lei de execução Penal

Ministério da Educação e Cultura

Ministério da Justiça 
MOBRAL

NINC

ONU

PEESP

PEP

PPPprisões

PROEJA

PROJOVEM

PRONASCI

PUB

SAP

SECADI

SEE

UF

UNESCO
Movimento Brasileiro de Alfabetização

Núcleo de Inclusão

Organização das Nações Unidas

Plano Estratégico de Educação no Âmbito do Sistema Prisional

Programa de Educação nas Prisões

Projeto Político Pedagógico Educação nas Prisões

Programa de Educação Profissional para Jovens e Adultos

Programa Nacional de Inclusão de Jovens

Programa Nacional de Segurança Pública com Cidadania

Programa Unificado de Bolsas

Secretaria de Estado de Administração Penitenciária

Secretaria de Educação Continuada, Alfabetização, Diversidade e Inclusão

Secretaria Estadual de Educação

Unidade Federativa

Organização das Nações Unidas para a Educação, a Ciência, Educação

e Cultura 


\section{SUMÁRIO}

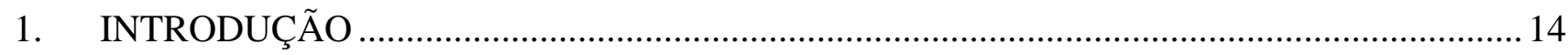

2. BREVE TRAJETÓRIA DE EDUCAÇÃO NO CÁRCERE NO BRASIL …………….................35

2.1. Políticas de segurança pública e execução penal .........................................................................52

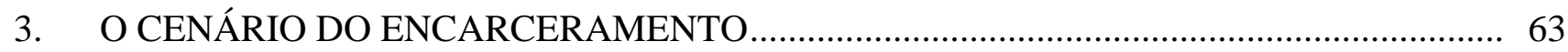

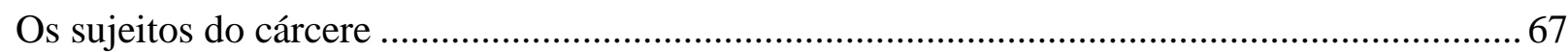

3.2. A falsa dicotomia do encarceramento: punição para ressocialização ………………………........70

4. EDUCAÇÃO EM CONTEXTO DE PRIVAÇÃO DE LIBERDADE: NOVOS PARADIGMAS 73

4.1. Projeto político pedagógico, uma conquista da Educação brasileira .............................................. 81

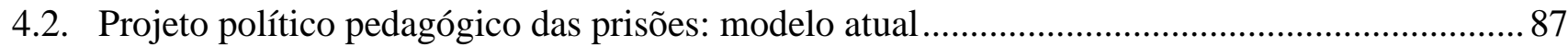

4.3. Projeto político pedagógico da Educação em prisões (PPPprisões): proposições do

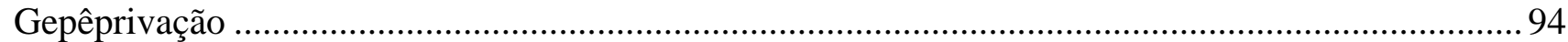

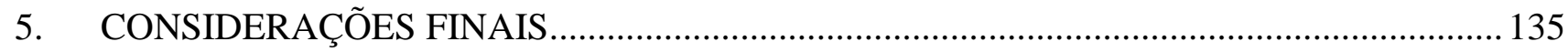

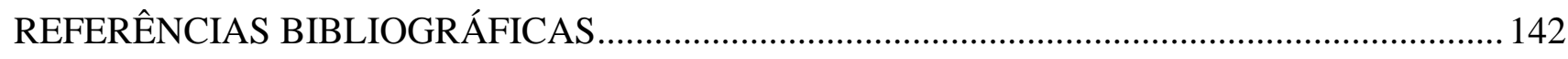




\section{INTRODUÇÃ̃}

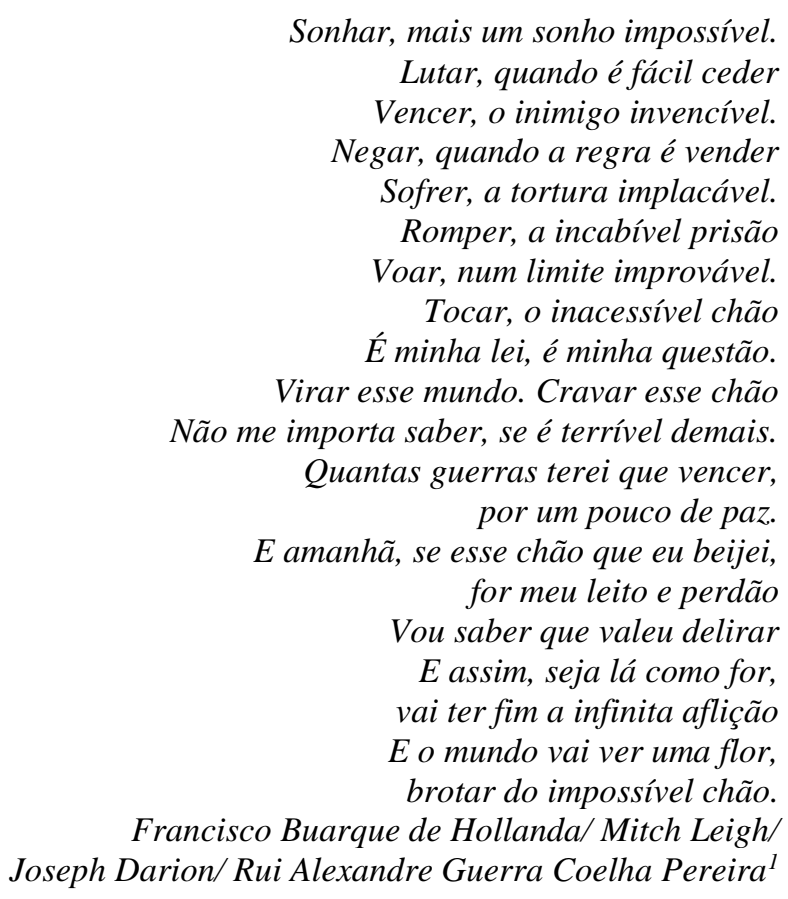

Sou mais uma filha de migrantes nordestinos, que traz cunhada na essência toda a luta e força de sua família para sobreviver às mazelas dessa vida. Minha trajetória como educadora começa aos 17 anos, como estudante de magistério ${ }^{2}$ na cidade de General Salgado, no interior de São Paulo, fazendo estágio como professora na mesma escola pública onde cursava o curso de magistério noturno. Desde sempre a escola pública me acolhe e é nela que se forja minha trajetória profissional e acadêmica.

Aos 18 anos, me efetivo como professora de séries anos iniciais (1' a 5' série) na cidade de Diadema. Neste mesmo ano tenho meu primeiro contato com a Educação de Jovens e Adultos (EJA) e a partir daí a EJA permeará toda minha trajetória como educadora, pois além de atuar como professora na rede pública, alguns anos depois também atuo como professora e coordenadora pedagógica no Colégio Cônegas de Santo Agostinho ${ }^{3}$, após concluir o curso de História.

\footnotetext{
${ }^{1}$ Canção Sonho impossível. Referência: https://www.jobim.org/chico/handle/2010.2/2210. Acesso: 03/04/2020

2 Magistério: curso a nível de Ensino Médio que habilitava professores para lecionar para educação básico de 1 a 5 série. 3 A instituição das cônegas de Santo Agostinho, atuante em São Paulo desde 1933, é um grupo ligado à Igreja Católica e aos movimentos populares da cidade de São Paulo. In: http://forumeja.org.br/br/book/export/html/2976
} 
Concomitante às aulas ministradas na EJA do Colégio Cônegas de Santo Agostinho, já morando na região central de São Paulo, também assumo a coordenação de uma escola de Ensino Fundamental, séries iniciais, na Região da Cracolândia, também na Gestão, como Diretora de uma escola que se torna vinculadora do Centro de Progressão Penitenciária Feminino (CPPF) do Butantã, tenho meu primeiro contato com a Educação de Jovens e Adultos em privação de liberdade. Participo do processo de implementação dessa política pública deliberando sobre as primeiras ações que viabilizam o atendimento das Diretrizes Nacionais para Educação ${ }^{4}$ em prisões no CPPF.

Após o primeiro ano de atuação junto ao CPPF, na função de Supervisora de Ensino da Secretaria do Estado de Educação de São Paulo assumo o acompanhamento os Programa de Educação em Prisões e Projeto Fundação Casa.

Como Supervisora de Ensino busco sanear as questões que estão colocadas para a efetivação do Programa Educação em Prisões, através de uma ação propositiva junto ao Núcleo de Inclusão (NINC) na Secretária de Educação do Estado de São Paulo. Minha aproximação com o NINC se estreitou com a chegada da Agente Executiva Carolina Bessa, responsável por permitir que o Programa Educação nas Prisões, avançasse na produção de muitos documentos legais que propiciariam progressos na implementação do programa.

Carolina Bessa, à época doutoranda do Programa de Pós-Graduação em Educação da USP. sob orientação do professor Dr. Roberto da Silva, também propiciou a minha aproximação ao Grupo de Estudos e Pesquisas sobre Educação em Regimes de Privação de Liberdade (GEPÊPRIVAÇÃO). Considero bastante oportuna essa parceria, posto que conseguimos a efetivação de diversos projetos, entre eles a discussão do Currículo para o ensino nas prisões e da formação de professores. Ainda, a efetivação de cooperação entre a Diretoria de Ensino Centro Oeste, com a Faculdade de Educação da Universidade de São Paulo (FEUSP) e GEPÊPRIVAÇÃO, contribuiu para que, em outubro de 2016, fosse celebrado um convênio, que teve como objetivo

[...] o desenvolvimento do Curso de Aperfeiçoamento "DOCÊNCIA EM REGIMES DE PRIVAÇÃO DA LIBERDADE" para atendimento educacional às unidades de privação da liberdade de adolescentes, jovens e adultos sob responsabilidade da Diretoria de Ensino da Região Centro Oeste da cidade de São Paulo (DOE, 2016).

\footnotetext{
4 Diretrizes nacionais para educação em prisões.

Link: http://portal.mec.gov.br/index.php?option=com_docman\&view=download\&alias=5142-rceb002-

10\&category_slug=maio-2010-pdf\&Itemid=30192. Acesso em: 002/02/2019.
} 
Uma das ações desenvolvidas foi a realização de um Curso de Aperfeiçoamento durante o $2^{\circ}$ semestre de 2017, que teve a participação da quase a totalidade dos professores e professoras que atuavam nas escolas vinculadoras adstritas à Diretoria de Ensino Região Centro Oeste (DECTO) cerca de 100 profissionais e contou com a colaboração dos professores Maria Clara Di Pierro (EJA), Núria Hanglei Cacete (História), Sandoval Nonato Santos (Linguística), Vinício de Macedo Santos (Matemática), Lúcia Sasseron (Ciências da Natureza), todos da FEUSP, além de Carolina Bessa (SEE/SP), profissionais da DECTO e bolsistas de diversos cursos de Licenciaturas da FEUSP que fizeram o acompanhamento dos professores em sala de aulas.

Nessa colaboração entre DECTO e a FEUSP foi de fundamental importância o apoio institucional da USP por meio da concessão de financiamentos e de bolsas para o desenvolvimento das ações educacionais, que se transformaram em projetos de iniciação científica para os bolsistas do Programa Unificado de Bolsas (PUB) e do Programa Aprender na Comunidade e da Equipe ligada à DECTO.

Para além dessa aproximação profissional bastante profícua, surge para mim a oportunidade de investimento nas discussões relacionadas a educação nas prisões como pesquisa acadêmica. A realização bem sucedida do Curso de Aperfeiçoamento em Docência em Regimes de Privação da Liberdade, juntamente com a premente necessidade individual de cada vez mais fundamentar a minha atuação profissional junto ao Programa de Educação em prisões, a partir também de estudos acadêmicos relacionados ao tema, faz renascer o antigo desejo de me dedicar a academia, que foi reforçado com o convite do professor Dr. Roberto da Silva para que eu concorresse a uma vaga no processo seletivo do Mestrado no programa de pós-graduação na área de Estado, Sociedade e Educação.

O GEPEPRIVAÇÃO, grupo de estudo e pesquisa acadêmica, composto por pesquisadores da Faculdade de Educação da Universidade de São Paulo e do Instituto Paulo Freire, focados em investigar regimes de intuições de privação de liberdade, é coordenado pelo professor Doutor da faculdade de educação da FEUSP, Roberto da Silva e formado por pesquisadores da Faculdade de Educação da Universidade de São Paulo e do Instituto Paulo Freire. São elementos de pesquisa do grupo o universo de jovens e adultos a quem se atribui a autoria de ato infracional; as prisões femininas e masculinas; os presídios especiais, como os das polícias civil, militar e das forças armadas. Outro foco do grupo é buscar identificar as ações pedagógicas praticadas nas instituições e 
como formar os profissionais da educação e das demais áreas que atuam nesses locais. A interdisciplinaridade é uma das ferramentas usadas para estudar as políticas públicas referentes a execução da medida socioeducativa, para adolescentes e da execução penal, para adultos. Ao levar o pesquisador para dentro das instituições, indo além da pesquisa teórica, o GEPEPRIVAÇÃO também experimenta hipóteses de trabalho, como forma de produzir novos conhecimentos, se envolvendo diretamente com os sujeitos desses ambientes.

O Projeto Político Pedagógico Educação das Prisões (PPPprisões) é originalmente o título de um conjunto de ações desenvolvidas pelo GEPÊPRIVAÇÃO desde 2015 e que congrega mestrandos e doutorandos da USP, além de pesquisadores de diferentes universidades e países. Cada pósgraduando ou bolsista de iniciação científica integrante do GEPÊPRIVAÇÃO tem seu próprio projeto individual de pesquisa, que no seu conjunto, contemplam diferentes dimensões da Educação em prisões e elementos do PPP. Este trabalho é de minha autoria individual e contou com a contribuição de um coletivo, cujos aportes serão apresentados nesta dissertação de Mestrado.

Ressalto que para além de orientador, o professor Doutor Roberto da Silva, promoveu um acréscimo efetivo no desenvolvimento e no contínuo aumento de repertório acadêmico ligado ao tema educação em prisões. Nesses anos de parceria e sob sua orientação foi possível, através do acompanhamento cotidiano do seu trabalho, das indicações de pesquisas e bibliografias, das observações in loco de espaços de privação de liberdade no interior de São Paulo, em Minas Gerais, Salvador e Angola, e por fim, das reuniões do GEPEPRIVAÇÃO, desenvolver uma reflexão histórica e crítica sobre a evolução e efetivação de direitos à Educação em espaços de privação de liberdade.

Também com o professor Dr. Roberto da Silva foi possível pesquisar e desenvolver atividades na área de Pedagogia Social e suas respectivas práticas em educação social, popular e comunitária, os limites e a necessidade de reinvenção do conceito de Educação Popular, discutindo e investigando a partir de matrizes de aprendizagem, de implementação de alfabetização científica e considerando ainda, a linguagem pedagógica e diversos conflitos sociais existentes para os novos sujeitos de direito à educação. A Pedagogia Social é fundamental para esta dissertação, posto que minha proposta tem como perspectiva dar ênfase as práticas de educação escolar e extracurricular, especialmente no atendimento às minorias sociais em seus respectivos territórios, como é o caso das prisões.

Para Roberto da Silva, a Pedagogia Social reporta à Escola a tarefa de promover a inserção, a igualdade e a ascensão social de parcelas significativas da população brasileira, mesmo que os 
sistemas escolares e o corpo docente não estejam estrutural, teórica e metodologicamente preparados para entender, aceitar e operacionalizar a escola e a educação como instrumentos de justiça social.

Aponto também a discussão empreendida pelos pesquisadores do GEPEPRIVAÇÃO sobre um sistema jurídico e administrativo perverso, existente no Brasil, que administra a problemática da exclusão, não se preocupando em romper com a trajetória da marginalização e criminalizando os não brancos, não cristãos, não proprietários, não letrados. A educação só poderá romper esse círculo quando passar a reconhecer os novos sujeitos de direitos que não estão adequados a esse sistema. $\mathrm{O}$ reconhecimento dos sujeitos de direitos faz emergir a necessidade de uma nova perspectiva de educação, faz-se necessário criar fissuras na escola que é o lócus de reprodução de determinadas classes e onde esses novos sujeitos de direito não estão assistidos.

Nesse sentido, é necessário forjar o professor no campo da pedagogia social, compor quadros de docentes, desenvolver um trabalho de afirmação de direitos. E ainda, assim como Paulo Freire (1999), concebo a educação como libertação entendendo que a garantia desse direito também é equivalente a libertar, pois são corolários da educação que defendemos, a conscientização, a autonomia, a emancipação, a capacidade de autodeterminação e a vocação para ser mais.

Na concepção freiriana, humanização e desumanização são possibilidades dos homens como seres inconclusos e conscientes da sua inconclusão, mas se ambas constituem uma possibilidade só a primeira parece constituir a vocação do homem. A desumanização é "uma distorção da vocação de ser mais; distorção possível na história, mas não é uma vocação histórica”. E ainda que a desumanização seja real na história, não é um destino contra o qual não se possa lutar, mas "o resultado de uma ordem injusta que gera violência por parte dos opressores, que por sua vez, gera o ser menos" (Freire, 1987, p. 48). Essa concepção torna responsabilidade da educação a tarefa humanística e histórica de libertar-se a si e aos seus opressores. Oprimido e opressor devem ser entendidos como categorias dialéticas e relativas, dadas a natureza cambiante das relações humanas e sociais e a possibilidade de uma mesma pessoa estar concomitantemente nas duas posições, ainda que em relação a pessoas diferentes (FREIRE, 1987, p. 16).

Paulo Freire (1997, p. 34) nos coloca também, que os problemas relacionados com a educação não são somente pedagógicos, mas sim políticos e éticos, e que os problemas da educação de adultos, particularmente nas prisões, evidenciam esse caráter ético e político. 
Os conceitos colocados acima são pontos centrais no desenvolvimento desta pesquisa.

Ainda discorrendo sobre o objeto dessa pesquisa, definições clássicas de crime, pena e prisão não são mais suficientes para explicar os processos sociais que estamos vivenciando neste início de século 21, marcado pelo acirramento das desigualdades sociais, da pobreza e do desemprego (Silva, Moreira, 2006, p. 5). Temos um cárcere cada vez mais destinado a pessoas de extratos sociais historicamente mais vulneráveis, que em liberdade não puderam desenvolver suas potencialidades humanas e não adquiriram escolarização ou profissionalização suficiente para lhes assegurar um lugar em suas comunidades.

Investigar e traçar caminhos a partir da demanda de uma política pública que responsabiliza as secretárias de educação dos estados pelo desenvolvimento e implementação da educação de pessoas privadas de liberdade é uma pauta que contribui para avançar nos modelos de educação, nas estratégias para proporcionar maior desenvolvimento da educação em território prisional, objetivando mudanças nestes espaços e nos sujeitos que transitam nele.

Compreendo que todos os programas e ações de educação em prisões, lograriam buscar desenvolver projetos fundamentando-se na Pedagogia Social e na Práxis da Educação Social. A Pedagogia Social é a disciplina acadêmica que concebe a educação como parte do processo de desenvolvimento social e não como investimento individual na pessoa. Aborda as questões sociais do ponto de vista pedagógico e não o inverso. A Educação Social, por sua vez, aborda a educabilidade social do sujeito e visa sua preparação para a vida em sociedade. Estas abordagens se mostram pertinentes ao contexto da privação da liberdade dado o entendimento que escolarização não é o único nem a principal deficiência que as pessoas apresentam e nem é a alfabetização e a elevação da escolaridade que vai levá-las a superar tantas deficiências apresentadas no entendimento das regras de convivência social, no exercício da responsabilidade social, na apropriação de códigos, símbolos e valores ou na postura ética diante da vida, dos outros e do mundo (SILVA, 2018).

À partir da Lei de Diretrizes e Bases da Educação Nacional (LDBN), onde se aponta que a educação "tem por finalidade o pleno desenvolvimento do educando, seu preparo para o exercício da cidadania e sua qualificação para o trabalho." e do Artigo 81 da LDBN, que permite "a organização de cursos ou instituições de ensino experimentais, desde que obedecidas as disposições desta Lei." ${ }^{\prime 5}$, trabalhamos ainda com uma proposta que considera

5 Fonte: http://www.planalto.gov.br/ccivil_03/LEIS/L9394.htm, acesso em 28/01/2019. 
pertinente a orientação curricular em torno do desenvolvimento de habilidades e competências, mas em respeito à especificidade do público que se tem em vista, indaga-se habilidades e competências escolares, de caráter lógico filosófico e lógico matemáticas são suficientes para superar o quadro geral de déficits historicamente acumulados por pessoas em regimes de privação da liberdade. Aqui nos sentimos compelidos a ampliar o conceito de habilidades e competências para considerar, de um lado, os fatores que levaram estas pessoas à quebra das regras de convivência social e à infração das leis estabelecidas e, de outro, a necessidade que elas têm de retornar ao convívio social como pessoas úteis, responsáveis e produtivas. Por esta razão recorremos ao conceito de habilidades e competências sociais tal como é empregado na área de Pedagogia Social. (SILVA, 2018, p.31).

Para além das concepções acima colocadas, considero também, conjuntamente a importância dos documentos jurídicos e a utilização desses para a implementação dos programas e projetos, dentre eles, a Base Nacional Comum Curricular (BNCC) $)^{6}$, que procura desenvolver a educação, a partir dos currículos dos sistemas e redes de ensino das Unidades Federativas, as competências e habilidades dos educandos. As habilidades estão associadas ao saber fazer e entre alguns exemplos, podemos citar: compreender fenômenos, relacionar informações, analisar situações-problema, sintetizar, julgar, correlacionar e manipular. As competências são o conjunto dessas habilidades desenvolvidas. As habilidades devem ser desenvolvidas na busca das competências. São as aptidões desenvolvidas ao longo de cada etapa de ensino, que contribuem para o desenvolvimento das competências. Ainda, o educador Paulo Freire afirmou, em conversa com os educadores que atuavam em prisões durante o I Encontro de Monitores de Educação de Adultos Presos do Estado de São Paulo (1993), que a singularidade da condição de presidiário não requer necessariamente um método pedagógico específico. Advertiu ainda que se os educadores que "enveredassem por uma metodologia específica, inclusive com materiais didáticos próprios, estariam discriminando o aluno preso duas vezes, negando-lhes acesso à informação/formação que de todos é de direito" (RUSCHE, 1995, p. 17).

Assim, no que se refere à educação de jovens e adultos privados de liberdade, considero que o papel da educação, também deve ser sim, como previsto na BNCC, o de ajudar o desenvolvimento de habilidades e competências para poderem desenvolver, neste período, melhores condições de acessarem direitos e oportunidades, quando reinseridos na sociedade. Ainda nesse campo específico, de educação de jovens e adultos (EJA), a Agenda para o Futuro da Educação de Adultos, resultante da V Conferência Internacional de Educação de Adultos (Confintea), em 1997, faz referência

\footnotetext{
6 A Base Nacional Comum Curricular é um documento normativo que define o conjunto de aprendizagens essenciais que todos os alunos devem desenvolver ao longo das etapas e modalidades da Educação Básica. Seu principal objetivo é ser a balizadora da qualidade da educação no País por meio do estabelecimento de um patamar de aprendizagem e desenvolvimento aos alunos. Fonte: http://basenacionalcomum.mec.gov.br/
} 
específica à população carcerária no Tema VIII, “A educação para todos os adultos: os direitos e aspirações dos diferentes grupos” (parágrafo 47):

Reconhecer o direito dos detentos à aprendizagem:

a) informando os presos sobre as oportunidades de ensino e de formação existentes em diversos níveis e permitindo-lhes o acesso a elas;

b) elaborando e pondo em marcha, nas prisões, amplos programas de ensino, com a participação dos detentos, a fim de responder às suas necessidades e aspirações em matéria de educação;

c) facilitando a ação das organizações não-governamentais, dos professores e dos outros agentes educativos nas prisões, permitindo, assim, aos detentos, o acesso às instituições educativas, estimulando as iniciativas que tenham por fim conectar os cursos dados na prisão com os oferecidos fora dela. ${ }^{7}$

Os diversos documentos que garantiram o direito a educação nos últimos anos, com destaque para a educação de jovens e adultos privados de liberdade, trouxeram mudanças nos modelos de gestão e implementação das políticas de educação em unidades prisionais nos Estados da Federação. Temos como novas fronteiras da educação pública, a de conceber os condicionantes para um projeto de educação em prisões que possibilite a complementaridade entre a legislação educacional e a penal, propicie a articulação entre políticas setoriais, possibilite a sinergia entre pedagogia e direito, professores, gestores e agentes penitenciários, em torno de objetivos comuns.

Ressalto a relevância dos marcos normativos para avançar na proposta de um projeto para educação em prisões que propicie formalização da trajetória escolar, a partir das experiências com projetos e disciplinas extracurriculares como ponto fundamental para essa pesquisa. Essas práticas, conforme determinam documentos oficiais, quando relacionadas às habilidades e conhecimentos previstos no Currículo Oficial, desde que apreendidas e significativas, poderão ser objeto de certificação (disciplinas, áreas do conhecimento e/ou conteúdos) e aproveitadas para compor a trajetória escolar dos alunos.

Também recorro aos instrumentos legais para demonstrar a dinamização da trajetória escolar, a garantia de acesso, a permanência e garantias de certificação e remição, a estrutura e organização

7UNESCO: Organização das Nações Unidas para a Educação, a Ciência e a Cultura.

Fonte: http://www.unesco.org/fileadmin/MULTIMEDIA/INSTITUTES/UIL/confintea/, acesso em 21/01/2019. 
escolar, considerando o território e mecanismos que impulsionem a trajetória escolar de privados de liberdade.

Temos no Brasil um número considerável de jovens e adultos que ainda não concluíram sua escolarização básica. A LDB 9394/1996, em seu art. 22, assegura que “a educação básica tem por finalidades desenvolver o educando, assegurar-lhe a formação comum indispensável para o exercício da cidadania e fornecer-lhe meios para progredir no trabalho e em estudos posteriores". Os documentos legais mostram ainda que:

[...] a presença desse conjunto de institutos na organização escolar responde a demandas específicas e que, para além das excepcionalidades a que eles se destinam, cabe às equipes e comunidade escolar, igualmente pensar e incorporarem seu projeto pedagógico, com base em diagnósticos locais, a previsão de outros programas que visem combater a retenção, promotora da defasagem idade/série e, por vezes, da própria evasão. Um bom exemplo a ser citado neste caso são os programas de Recuperação, concretizados de diferentes formas pela escola, grupo de professores, gestores e demais colaboradores. Por fim, nesse mesmo sentido, caberá à Secretaria de Estado da Educação a concretização de políticas públicas de base, quer seja para o atendimento de alunos, quer seja para a formação continuada de professores, gestores e demais profissionais que atuam na educação escolar, a fim de que os índices de defasagem idade/série e evasão cada vez mais sejam reduzidos e a qualidade social da educação acene para patamares de referência compatíveis com a formação e autonomia esperados no processo civilizatório (DELIBERAÇÃO CEE 155/17).

Outro ponto a se considerar é que hodiernamente todas as pessoas já nascem com garantias legais de direitos, que se apresentam a partir de ordenamento jurídico ou nas cartas legislativas, Os direitos fundamentais da pessoa, atualmente estão inseridos em grande parte das Constituições pelo mundo todo, através do constitucionalismo ${ }^{8}$, importante conquista do mundo contemporâneo que apresenta “[...] todos os seres humanos, apesar de inúmeras diferenças biológicas e culturais que os distinguem entre si, merecem igual respeito [...], nenhum indivíduo, gênero, etnia, classe social, grupo religioso ou nação, pode firmar-se superior aos demais" (COMPARATO, 2008, p 01).

No âmbito dos Direitos Humanos estão todas as dimensões relacionadas ao respeito à vida com dignidade. Para Maria Vitória Benevides (2007) “direitos humanos são aqueles comuns a todos,

8 https://ambitojuridico.com.br/cadernos/direito-constitucional/constitucionalismo-e-sua-historia/ 
a partir da matriz do direito à vida, sem distinção alguma". A autora, aponta ainda que no caso brasileiro, esses direitos:

[...] reconhecidos na Constituição Federal ou por meio de tratados, pactos e convenções dos quais o Brasil é signatário - são indivisíveis e irreversíveis: São irreversíveis porque à medida que são proclamados, tornando-se direitos positivos fundamentais, não podem mais ser revogados. São indivisíveis porque, numa democracia efetiva, não se pode separar o respeito às liberdades individuais da garantia dos direitos sociais; não se pode considerar natural o fato de que o povo seja livre para votar, mas continue preso às teias da pobreza absoluta (BENEVIDES, 2007, p 339).

A Constituição Federal do Brasil determina em seu artigo 6º a garantia aos direitos sociais do ser humano como a saúde, o trabalho, a moradia, o lazer, a segurança, a previdência social, a proteção à maternidade e à infância, a assistência aos desamparados, que devem ser respeitados, protegidos e garantidos a todos pelo Estado. Esses direitos passam a ser o centro de todo o ordenamento constitucional do sistema político, econômico e social. ${ }^{9}$

Aponto que ainda no âmbito jurídico, há um mínimo existencial a ser garantido aos indivíduos e à própria sociedade, relacionado à oferta de garantias absolutamente indispensáveis a uma existência digna da pessoa humana. Queiroz traduz o mínimo existencial, colocando que:

[...] trata do princípio da proibição da insuficiência, cuja finalidade é auxiliar no acompanhamento da concretização dos direitos sociais, quando se define, a partir da Constituição, um conteúdo mínimo de direitos fundamentais, ao qual o legislador estaria vinculado e proibido de suprimir sem uma compensação adequada (QUEIROZ, 2006, p. 105110).

Contudo, caminhando ao lado do mínimo existencial, temos ainda no ordenamento jurídico, a reserva do possível e formalidades orçamentárias, usualmente utilizadas pelo Poder Público como matéria de defesa e excludente de responsabilidade, levando em consideração a conformidade financeira do Estado, sua possível adequação e a necessidade do pedido, com critério proporcional. De acordo com Barcellos citado por Santos (2011, p. 5) “a expressão reserva do possível procura

9 Título II, dos direitos e garantias fundamentais, capítulo II, dos direitos sociais. Fonte: https://www.senado.leg.br/atividade/ const/con1988/con1988_15.12.2016/art_6_.asp 
identificar o fenômeno econômico da limitação dos recursos disponíveis diante das necessidades quase sempre infinitas a serem por eles supridas”.

No presidencialismo ${ }^{10}$, sistema político escolhido para organizar o Brasil, cabe aos líderes do Executivo, aos ministros e secretários de todas as esferas, exercerem a direção superior da administração pública e a efetivação dos direitos sociais a partir do arbítrio constitucional, promovendo a realização do sistema democrático. Entretanto, nos últimos anos, temos presenciado a judicialização da política, quando observamos que para que sejam cumpridos os preceitos e as garantias já constitucionais, o judiciário tem que se empenhar para a execução desses direitos.

Sunstein (2004) defende que mesmo em países pobres é possível a proteção dos direitos sociais, tendo a jurisdição constitucional vários modos para fazê-lo. Assinala ainda que:

\begin{abstract}
A Constituição Federal brasileira, prevê em seu texto, que em caso de omissão do governo na realização dos direitos sociais, este implemente políticas públicas progressivas razoáveis para assegurar que as minorias possam usufruir dos direitos sociais, especialmente em relação a direitos sociais, como moradia e trabalho, que exigem políticas públicas progressivas. Se o Estado não consegue demonstrar que está realizando essas políticas públicas, ou se ficar comprovado que tinha capacidade financeira para fazer algo melhor e maior, então poderá o Judiciário declarar que o governo está violando a Constituição (SUSTEIN, 2004, p. 227).
\end{abstract}

Apesar dos direitos sociais parecerem concluídos com sucesso, uma vez que estão institucionalizados e de existirem instrumentos de garantias desses direitos, através de leis, tratados e declarações, temos inúmeras situações concretas onde na prática não se concretiza esta garantia.

No que tange ao direito à educação, a Organização das Nações Unidas para a Educação, a Ciência e a Cultura preconiza que a educação é direito de todos, deve ser oportunizada nos mais diferentes contextos, à luz do direito humano à educação e do conceito de educação ao longo da vida:

O direito universal à educação para todas as crianças, jovens e adultos é o princípio fundamental que sustenta todas as nossas iniciativas. A educação de adultos é mais importante do que nunca na era da globalização, caracterizada por mudanças rápidas, integração e avanços tecnológicos. A aprendizagem emancipa os adultos, dando- -lhes conhecimentos e competências para melhorar suas vidas. Mas também beneficia suas famílias, comunidades e sociedades. A educação de adultos desempenha um papel crucial na

10 https://www.senado.gov.br/noticias/Especiais/eleicoes2010/historia/presidencialismo-nasceu-com-a-republica-e-foiconfirmado-por-plebiscito-em-1993.aspx 
redução da pobreza, na melhoria da saúde e da nutrição e na promoção de práticas ambientais sustentáveis. Assim sendo, a consecução de todos os Objetivos de Desenvolvimento do Milênio exige programas de educação de adultos relevantes e de qualidade.

$[\ldots]$

Uma compreensão geral da educação de adultos requer que se reconheça a diversidade de tipos de oferta, finalidades e conteúdo que podem ser incluídos em uma definição significativa. A educação de adultos é importante para o empoderamento pessoal, bem-estar econômico, coesão da comunidade e desenvolvimento social. Como setor, a educação de adultos contribui para a redução da pobreza e do desemprego, qualificação da força de trabalho, diminuição da propagação do HIV/Aids, preservação e conservação do meio ambiente, maior conscientização sobre os direitos humanos, combate ao racismo e à xenofobia, apoio aos valores democráticos e exercício ativo da cidadania, e fortalecimento da equidade e igualdade de gênero. Tudo isso tem como pano de fundo a necessidade urgente de aumentar os níveis de alfabetização de adultos, habilidades básicas e competências-- chave em todo o mundo e mais intensamente nos países do Sul. (UNESCO, 2006, p. 08-43).

Para além das considerações apresentadas acima, enfatizo que vivenciamos em âmbito nacional anos difíceis para aqueles que estão inseridos num contexto em que dependem do Estado para ter acesso aos direitos sociais, já garantidos pela Constituição. O avanço neoliberal provoca o desmonte das bases estatais construídas em 1930, aperfeiçoadas em 1988 e dinamizadas a partir de 2003.

Considero que com a atual conjuntura nacional, faz-se premente trabalhos que reafirmem que a educação no sistema penitenciário não pode ser entendida como privilégio, benefício ou, muito menos, recompensa oferecida em troca de bom comportamento. A educação é um direito fundamental de todos, homens e mulheres, independentemente do meio em que se encontram. A educação pode e deve contribuir para a formação de jovens e adultos, homens e mulheres, deve preocupar-se com indivíduos preparando-os para assumir seu papel no trabalho e na sociedade.

No que diz respeito às garantias legais relacionadas à educação em prisões, em 2010 temos a implantação das Diretrizes Nacionais para a Oferta da Educação em Estabelecimentos Penais no Brasil $^{11}$, orientada por eixos que deveriam envolver, de forma articulada, o sistema público de ensino

\footnotetext{
${ }^{11}$ RESOLUÇÃO CNE No 2, 2010. Dispõe sobre as Diretrizes Nacionais para a oferta de educação para jovens e adultos em situação de privação de liberdade nos estabelecimentos penais.

Fonte: https://www.diariodasleis.com.br/legislacao/federal/214297-diretrizes-nacionais-para-a-oferta-de-educauuo-parajovens-e-adultos-dispue-sobre-as-diretrizes-nacionais-para-a-oferta-de-educauuo-para-jovens-e-adultos-em-situauuode-privauuo.html.
} 
e a execução penal, por meio dos Ministérios da Educação (com ações das Secretarias de Educação)

e da Justiça (com ações da Administração Penitenciária ou equivalente nos Estados):

\begin{abstract}
Parágrafo Único. As parcerias a que se refere o caput deste artigo dar-se-ão em perspectiva complementar à política educacional implementada pelos órgãos responsáveis pela educação da União, dos Estados e do Distrito Federal.

Art. $7^{\circ}$ As autoridades responsáveis pela política de execução penal nos Estados e Distrito Federal deverão, conforme previsto nas Resoluções do Conselho Nacional de Política Criminal e Penitenciária, propiciar espaços físicos adequados às atividades educacionais, esportivas, Art. $6^{\circ}$ A gestão da educação no contexto prisional deverá promover parcerias com diferentes esferas e áreas de governo, bem como com universidades, instituições de Educação Profissional e organizações da sociedade civil, com vistas à formulação, execução, monitoramento e avaliação de políticas públicas de Educação de Jovens e Adultos em situação de privação de liberdade.

culturais, de formação profissional e de lazer, integrando-as às rotinas dos estabelecimentos penais.

Parágrafo Único. Os Estados e o Distrito Federal deverão contemplar no seu planejamento a adequação dos espaços físicos e instalações disponíveis para a implementação das ações de educação de forma a atender às exigências desta Resolução. ${ }^{12}$. (RESOLUÇÃO CNE $N^{\circ} 2$, 2010, P. 3).
\end{abstract}

A organização do trabalho pedagógico nas classes prisionais tem particularidades que estão configuradas nas Diretrizes Nacionais para oferta de educação a jovens e adultos em situação de privação de liberdade (Resolução CNE/CEB n 2/2010) e na LDB, para EJA.

A educação escolar dentro do cárcere traz em seu bojo as problemáticas que estão colocadas para a educação atualmente, e apesar da universalização do acesso, e de a última fronteira dessa universalização ser justamente educação no cárcere, ainda temos um grande caminho a percorrer.

Para Onofre e Julião (2013), a educação:

[...] em espaços de privação de liberdade apresenta-se como um fenômeno complexo, uma vez que o contexto prisional se revela singular, mas, ao mesmo tempo, semelhante a outros espaços educativos. Nele se cruzam e entrecruzam visões de mundo, de educação, de cultura, presentes na sociedade como um todo, adquirindo perspectivas peculiares da sociedade dos cativos (Sykes, 1999). Conhecer as rotinas e as relações de poder a que estão subjugados nessa sociedade e identificar os efeitos da cultura prisional sobre todos aqueles que transitam no ambiente prisional se constitui em ponto de partida para a construção de políticas públicas que se efetivem com algum sucesso. $O$ indivíduo em situação de privação de liberdade traz, como memória, vivências por vezes negativas, de situações pelas quais passou antes e durante sua carreira delinquencial. Em suas expectativas de futuro estão o desejo de começar uma nova vida, na qual possa trabalhar, voltar a estudar e construir uma família. [...]É o cotidiano que revela as bases sobre o que é possível, mas não deixa de trazer embutido o passado, como memória e incorporação de vivências. Sua expectativa de futuro é algo que deve ser também considerada, e a educação pode oferecer condições para que ele possa conviver, no presente, 
com diferentes circunstâncias, sabendo a hora de mostrar-se ou esconder-se, de falar ou de calar, de proteger-se para sobreviver." [...] (ONOFRE E JULIÃO, 2013, p. 59)

Pensar a educação para pessoas em situação de restrição de liberdade pressupõe compreender que esta educação acontece em um espaço peculiar, com uma cultura prisional, que visa adaptar o indivíduo ao cárcere. Mayer (2013) observa que:

[...] existem dois grupos de aprendizagens próprios das prisões: as regras oficiais (da instituição) e as regras não oficiais (dos próprios presos), ainda que algumas dessas regras se sobreponham umas às outras. [...] tudo isso é educação da prisão, não a educação na prisão.

[...] A educação do cárcere visa a adaptação dos sujeitos às normas do sistema prisional, enquanto a educação no cárcere é uma ferramenta para a libertação dos oprimidos. Sem ignorar que a cultura escolar na prisão é atravessada pela cultura da prisão, é importante destacar que o processo de aprendizagens não pode se restringir à sobrevivência neste espaço.

[… É necessário, então, que a prisão ensine algo de diferente da própria prisão." (MAYER, 2013, p. 42-44).

As pessoas em privação de liberdade, embora suspensas por tempo determinado do direito de ir e vir, têm garantidos por lei os demais direitos, e a educação é um deles, entretanto a educação para pessoas presas ainda é vista como um privilégio, pois a oferta de educação básica é algo estranho no cotidiano do sistema penitenciário.

Como resultado das diretrizes nacionais para educação aos privados de liberdade, evoluem as discussões e pesquisas sobre o tema, organizam-se audiências públicas para elaboração dos Planos Estaduais de Educação para os Sistemas Prisionais com a participação de integrantes de grupos de pesquisa, comissões e sociedade civil organizada para se discutir os problemas específicos de cada Estado, visando acompanhar os desdobramentos de ações planejadas com base no "Plano Estratégico de Educação do Sistema Prisional” (BRASIL, 2011).

No país, a implantação de uma política pública dessa envergadura provocou impacto orgânico e estrutural relacionado à execução penal e as Secretarias de Educação e como já citado brevemente, desde que iniciei carreira na educação, em 1989, atuo em escolas públicas, incluindo aulas e coordenação em Educação de Jovens e Adultos. Como Supervisora de Ensino, na Diretoria de Ensino da Região Centro Oeste do Estado de São Paulo, venho desenvolvendo ação de acompanhamento e implementação dessas políticas públicas de educação em prisões, sob a perspectiva de uma educação que forme integralmente o ser humano. 
O Estado de São Paulo abriga a maior população presa do Brasil ${ }^{13}$ e, também por isso, somado a aspectos históricos da execução da política educacional, apresenta peculiaridades no que se refere à oferta de educação em prisões. Em São Paulo, desde 1979, a Fundação Estadual de Amparo ao Trabalhador Preso (FUNAP) ${ }^{14}$, instituição vinculada à Secretaria de Estado de Administração Penitenciária (SAP), oferecia Programa de Educação Básica às pessoas recolhidas no sistema, com foco na formação dos presos e na preparação de presos como monitores.

A partir de 2011, com as Diretrizes Nacionais para a Oferta da Educação em Estabelecimentos Penais aprovadas pela Resolução n ${ }^{\circ}$ 3, de 11 de março de 2009, a demanda da FUNAP sofre modificações no que tange a condução da educação prisional. Assim, para garantir a oferta de educação a jovens e adultos, privados de liberdade, à luz do disposto na Lei de Diretrizes e Bases da Educação Nacional, mediante ao Programa de Educação nas Prisões (PEP), instituído pelo Decreto Estadual 57.238/2011, pelo Termo de Cooperação celebrado, entre a Secretaria da Administração Penitenciária (SAP), Secretaria da Educação e a Fundação "Dr. Manoel Artur Pedro Pimentel (FUNAP), têm-se o objetivo de definir as responsabilidades institucionais na oferta da Educação Básica, na modalidade Educação de Jovens e Adultos (EJA), em situação de privação de liberdade nos estabelecimentos penais do Estado de São Paulo e unidades psiquiátricas.

Em 2013, a Secretaria Estadual de Educação assume efetivamente a educação nas prisões paulistas. São diversas ações a serem empreendidas. Podemos exemplificar como encaminhamentos adotados em São Paulo: elaboração de normativas conjuntas, definição e elaboração de procedimentos escolares e de entrada na unidade prisional, revisão da rotina prisional, formação e atualização de profissionais e a organização do ensino nas classes criadas dentro das unidades prisionais e respectivas escolas vinculadoras.

13 Em15/10/2020, o Departamento Penitenciário Nacional (Depen) lança o levantamento nacional de informações penitenciárias com dados do primeiro semestre de 2020. Segundo o SISDEPEN (sistema de informações do Departamento Penitenciário Nacional) o número total de presos e monitorados eletronicamente do sistema penitenciário brasileiro é de 759.518. O estado de São Paulo, tem 218.909 presos e o estado de Minas Gerais aparece em segundo lugar com 69912 presos e o estado do Paraná aparece em terceiro lugar com um número de 50959 presos. In: https://app.powerbi.com/view?r=eyJrIjoiMjU3Y2RjNjctODQzMi00YTE4LWEwMDAtZDIzNWQ5YmIzMzk1IiwidCI 6ImViMDkwNDIwLTQ0NGMtNDNmNy05MWYyLTRiOGRhNmJmZThlMSJ9 (acesso em07/ 01/2021)

14 A FUNAP - Fundação "Prof. Dr. Manoel Pedro Pimentel" de Amparo ao Preso - planeja, desenvolve e avalia programas sociais para os presos e egressos (ex presidiários) das 142 penitenciárias do Estado de São Paulo, em conjunto com a SAP - Secretaria de Administração Penitenciária, oferecendo estudo, qualificação, aprendizado profissional e oportunidade de trabalho remunerado. 
Para tanto, as equipes de gestão envolvidas (SAP e SEE), precisam estar articuladas e disponíveis para implementação estrutural da oferta de educação, modalidade EJA, no sistema prisional, por meio de seus órgãos centrais, regionais e locais, e profissionais, respeitando-se os âmbitos de atuação legal, estrutura, atribuições e competências legais

A oferta de EJA no sistema prisional tem especificidades estruturais e pedagógicas, no que se refere a transformação dos presos em alunos, à adaptabilidade ao contexto prisional, ao espaço e ao tempo, às características do local de atuação docente em que se encontram os estudantes, às limitações e às regras específicas.

Ireland (2011), outro importante pesquisador do tema, chama atenção que quando pensamos em Educação de Jovens e Adultos, é importante considerar que esse processo educacional também relaciona-se com questões próprias da política de execução penal e avalia:

A educação para jovens e adultos em situação de privação de liberdade sofre de limitações similares às da EJA quando realizada em outros contextos. Entender a educação em prisões como parte integrante da educação de adultos é importante politicamente para reforçar políticas públicas e por ser parte de um movimento que tem potencial de trazer benefícios mais amplos. Ao mesmo tempo, no caso da educação em prisões, não há como se esquecer de que o processo educacional se dá no contexto de uma política de execução penal que, embora considerada "moderna" e exemplar, impõe questões específicas (IRELAND, 2011, p. 30-31)

Acompanhando o Programa Educações em Prisões, nas Unidades Prisionais que se localizam na Região Centro Oeste, tenho como algumas ações, auxiliar a efetivação desse segmento, tanto nos aspectos pedagógicos como também estruturais. Dentre os aspectos estruturais, algumas características da variante encontrada nessa modalidade são as classes organizadas de modo multisseriados ${ }^{15}$, vinculadas a escolas estaduais mais próximas, visando atender a rotatividade de alunos, a demanda potencial e os diferentes perfis de escolaridade, na busca de otimização de espaços e tempos desta oferta. A vinculação é indicada pela Diretoria de Ensino mais próxima da Unidade Prisional, bem como a solicitação de instalação desse tipo de ensino na escola, visando atender as demandas dos alunos das classes vinculadas ${ }^{16}$. A escola é a responsável pela documentação,

\footnotetext{
15 Salas multisseriadas: Ensino Fundamental - Anos Iniciais $\left(1^{\circ}\right.$ ao $5^{\circ}$ ano $)$; Ensino Fundamental - Anos Finais $\left(6^{\circ}\right.$ ao $9^{\circ}$ ano) e de Ensino Médio ( $1^{\circ}$ ao $3^{\circ}$ ano).

16 Classes vinculadas: localizam-se dentro da Unidade Prisional, mas estão sob jurisdição de uma escola pública estadual.
} 
prontuários, certificação e acompanhamento pedagógico dos alunos, além de reuniões formativas com os professores. A matrícula pode ocorrer a qualquer época do ano, independentemente de documento pessoal, assim como a abertura de classes autorizada pela Diretoria de Ensino, vinculadas a uma escola estadual, obedecendo à legislação educacional vigente. A Diretoria de Ensino é responsável pelas ações pedagógicas, por meio do Núcleo Pedagógico e da Supervisão de Ensino.

Considero importante a descrição acima para pontuar os trâmites e o trânsito in loco desta pesquisadora nos centros prisionais onde são desenvolvidas as aulas da educação escolar na região supracitada. O presente trabalho é resultado dessa trajetória e tem como seu fio condutor a educação como direito social e discorre, fundamentalmente sobre o desenvolvimento de um percurso de prática de trabalho e pesquisa acadêmica concernente à Educação de Jovens e Adultos em Unidades Prisionais, analisando a pertinência de que a Educação e o conjunto de atividades de interesse da Educação desenvolvidas no âmbito das unidades prisionais, possam ser organizadas, administradas e avaliadas nos moldes de Projeto Político Pedagógico.

A presente pesquisa apresenta a possiblidade de organização dos territórios prisionais a partir da adoção do modelo de Projeto Político Pedagógico, seja para a gestão da Educação dentro da unidade prisional, seja para a gestão de todas as atividades formais de interesse da Educação realizadas dentro da unidade prisional.

O texto desse trabalho foi dividido da seguinte forma: o primeiro capítulo discorre sobre o histórico e problemáticas ligadas ao tema, educação no cárcere. O segundo capítulo traz um panorama dos sujeitos e territórios do cárcere e por fim, no terceiro capítulo, apresento o projeto político pedagógico enquanto política pública da educação e a análise da viabilidade da gestão do PPP nos espaços de educação das escolas nas unidades e das próprias unidades prisionais, à luz do que preconiza a $\mathrm{CNE} / \mathrm{CEB} \mathrm{n}^{\mathrm{o}} 2^{17}$. Entre algumas das questões analisadas estão: como o PPP pode potencializar projetos diversos de educação a todos os sujeitos imbricados neste contexto; a gestão compartilhada entre as Secretarias de Administração Penitenciárias e as Secretarias Estaduais de

17 RESOLUÇÃO Nº 2, DE 19 DE MAIO DE 2010. Dispõe sobre as Diretrizes Nacionais para a oferta de educação para jovens e adultos em situação de privação de liberdade nos estabelecimentos. Disponível em: http://portal.mec.gov.br/index.php?option=com_docman\&view=download\&alias=5142-rceb002-10\&Itemid=30192. Acesso: 23/03/2021. 
Educação no território prisional; articulação entre todas as atividades educacionais; articulação entre diferentes ciências e áreas de conhecimento.

Art. $2^{\circ}$ As ações de educação em contexto de privação de liberdade devem estar calcadas na legislação educacional vigente no país, na Lei de Execução Penal, nos tratados internacionais firmados pelo Brasil no âmbito das políticas de direitos humanos e privação de liberdade, devendo atender às especificidades dos diferentes níveis e modalidades de educação e ensino e são extensivas aos presos provisórios, condenados, egressos do sistema prisional e àqueles que cumprem medidas de segurança.

Art. $3^{\circ} \mathrm{I}$ - A oferta de educação para jovens e adultos em estabelecimentos penais obedecerá às seguintes orientações: I - é atribuição do órgão responsável pela educação nos Estados e no Distrito Federal (Secretaria de Educação ou órgão equivalente) e deverá ser realizada em articulação com os órgãos responsáveis pela sua administração penitenciária, exceto nas penitenciárias federais, cujos programas educacionais estarão sob a responsabilidade do Ministério da Educação em articulação com o Ministério da Justiça, que poderá celebrar convênios com Estados, Distrito Federal e Municípios;

[...] Art. III - estará associada às ações complementares de cultura, esporte, inclusão digital, educação profissional, fomento à leitura e a programas de implantação, recuperação e manutenção de bibliotecas destinadas ao atendimento à população privada de liberdade, inclusive as ações de valorização dos profissionais que trabalham nesses espaços;

Art. 10 As atividades laborais e artístico-culturais deverão ser reconhecidas e valorizadas como elementos formativos integrados à oferta de educação, podendo ser contempladas no projeto político-pedagógico como atividades

curriculares, desde que devidamente fundamentadas.

Art. 12 O planejamento das ações de educação em espaços prisionais poderá contemplar, além das atividades de educação formal, propostas de educação não-formal, bem como de educação para o trabalho, inclusive na modalidade de Educação a Distância, conforme previsto em Resoluções deste Conselho sobre a EJA (BRASIL, 2010, p. 2 - 4)

Como já anunciado, a dissertação constitui-se da propositura de viabilidade de adoção do modelo de Projeto Político Pedagógico para as Unidades Prisionais, para isso foi necessário pesquisar as legislações, normas e regulamentos e como elas são implementadas nos diferentes estados federativos.

No que corresponde a pesquisa documental, fontes primárias desta pesquisa, delineei a pesquisa considerando o processo hermenêutico de análise das fontes. Gadamer (2013), nos aponta, que considerar o processo hermenêutico é considerar em que sentido as teorias e as ações foram contextualizadas ou descontextualizadas, as experiências de estranhamento que ela nos causa, as diferenças no uso da linguagem, localizando-as historicamente, de modo que os preconceitos sejam vistos, desconstruídos e/ou reconfigurados em um outro contexto.

Alguns conceitos utilizados em publicações e vastamente discutidos, tais como: educação do cárcere, educação no cárcere, ressocialização, reintegração, reinserção, entre outros conceitos são 
empregados nesta dissertação, no entanto, não me aprofundei em análises que girem em torno de problematização de tais conceitos. Silva (2006, p. 06) apontou que reabilitação, reeducação, ressocialização, reinserção social e outros res são termos equivalentes para designar a pretensão dos discursos bem-intencionados com vistas a alcançar os fins da chamada terapia penal: devolver a pessoa presa à sociedade para que ela possa ser um cidadão útil e produtivo. Ainda assim, optei por utilizar as terminologia "reintegração", considerando a observações de Braga (2014, p. 350) que afirma que há pontos que diferenciam a terminologia reintegração social das ideologias "res". Para o autor, o preso é um indivíduo, circunstancialmente sujeito da Execução Penal e, portanto, deve poder manifestar sua vontade e autonomia nas atividades desenvolvidas em âmbito prisional e cabe a toda sociedade a corresponsabilidade pela "reintegração social".

A minha proximidade com o modelo atualmente adotado em SP e as pesquisas desenvolvidas permitiram a apropriação de um saber a partir da prática, uma observação não estática, ou deslocada dos contextos em que estão inseridos. Nesse sentido, como Saviani (2005), entendo que:

[...] a prática será tanto mais coerente e consistente, será tanto mais qualitativa, será tanto mais desenvolvida quanto mais consistente for a teoria que embasa, e que uma prática será transformada à medida que exista uma elaboração teórica que justifique a necessidade da sua transformação e que proponha as formas de transformação, estamos pensando a prática a partir da teoria. Mas é preciso também fazer o movimento inverso, ou seja, pensar a teoria a partir da prática, porque se a prática é o fundamento da teoria, seu critério de verdade e sua finalidade, isto significa que o desenvolvimento da teoria depende da prática (SAVIANI, 2005, p.107).

Como Supervisora de Ensino, tendo como uma das práticas de atuação, acompanhar e trazer proposições de políticas públicas do Programa de Educação nas Prisões, compreendo que a escola vive sob a dicotomia de reprodução das classes sociais e estabeleci como meu caminho o de acreditar na possibilidade de uma escola que oferta saberes e que viabiliza práticas emancipatórias, e é sob a concepção desta escola que direcionei não só as práticas de atuação, como os encaminhamentos relacionados a investigação desta dissertação.

Desde 2015, o Programa de Educação em Prisões da Diretoria de Ensino Centro Oeste tem um convênio com o Prof. Doutor da Faculdade de Educação da Universidade de São Paulo, onde estão elencadas atividades de formação de professores, de apoio à aprendizagem e ações de pesquisa desenvolvidas por bolsistas do grupo GEPEPRIVÇÃO em apoio à busca de resposta à hipótese dessa pesquisa. Para Certeau (2008) a narrativa historiográfica, apresenta-se como uma interpretação, uma 
adaptação criativa do pesquisador utilizando-se do suporte teórico-metodológico historiográfico, produzido pelo ambiente e suas relações.

Toda pesquisa histórica se articula com um lugar de produção socioeconômico, político e cultural. Ela está, pois, submetida a imposições, ligada a privilégios, enraizada em uma particularidade. É em função deste lugar que se instauram os métodos, que se delineia uma topografia de interesses, que os documentos e as questões, que lhes serão propostas, se organizam. (CERTEAU, 2008, p. 66.)

Assim, também contribuirá com o trabalho, como fonte secundária, as memórias, relatos e relatórios produzidos pelas pessoas ou pelo grupo GEPEPRIVAÇÃO,

Como já observei, apesar de podermos sim reproduzir nos espaços das prisões, a sala de aula, sabemos que o contexto geral dessa escola é muito diferente. Outras ciências estão imbricadas e atuando no mesmo espaço onde as atividades de educação desenvolvem-se. Temos dentro das unidades prisionais, aulas com professores vinculados as escolas pertencentes a Rede Estadual de Ensino, atividades laborais, esportivas, recreativas.

Em trabalho sobre a especificidade da pedagogia como ciência da educação FRANCO (2000, p. 83) coloca muito bem o mote desta pesquisa, quando aponta "o objetivo da pedagogia como ciência da educação, será o esclarecimento reflexivo e transformador da práxis”. Assim, relembro que quem acompanha a escola dentro das unidades, necessariamente tem que periodicamente frequentar as unidades prisionais e buscar dialogar com alguns sujeitos que atuam no cárcere, portanto foi possível, análise de contexto, adotando como fontes terciárias de pesquisa as escolas vinculadoras e as unidades prisionais, a partir do método de observação participante.

Diante da abrangência do tema desta pesquisa, acredito que a abordagem qualitativa, aliada com a pesquisa-ação, como investigação formativo-emancipatória que requer fundamentalmente o modelo do agir comunicativo, tenha sido a mais adequada estratégia de ação, possibilitando compreender o objeto de estudo no contexto que ocorre. Nessa pesquisa os métodos de abordagem foram essencialmente procedimentais, posto que desenvolvi análise documental, histórica e de observação, com a participação efetiva do GEPEPRIVAÇÃO. A realização de pesquisa em ambientes onde acontecem as próprias práticas e onde se tem a dimensão metodológica referente a processos de conhecimento utilizados, propicia melhor apropriação e cientificação dessa práxis. Para FRANCO, 
[...] a pesquisa-ação pode e deve funcionar como uma metodologia de pesquisa, pedagogicamente estruturada, possibilitando tanto a produção de conhecimentos novos para a área da educação, como também formando sujeitos pesquisadores, críticos e reflexivos, instigando-nos a refletir sobre sua essencialidade epistemológica, bem como sobre suas possibilidades como práxis investigativas. (FRANCO, 2000, pág. 489)

A pesquisa-ação se pauta na integração entre o sujeito e sua existência; entre fatos e valores; entre pensamento e ação; e entre pesquisador e pesquisado. Ela se faz a partir de uma abordagem de pesquisa que parte do pressuposto de que pesquisa e a compreensão das práticas possam levar a resolução dos problemas, a produção de conhecimentos e/ou a melhoria de uma situação dada. Ainda, me referenciando em CORAZZA (2002)

[...] nenhum modo de pensar a Educação é sagrado ou profano, verdadeiro ou falso, nobre ou vulgar, rico ou indigente. Um pensador não pode provar, comparar, medir, decidir que o seu modo de pensar é melhor do que os modos que constroem outros conceitos, planos e personagens. Os critérios para tal comprovação não são senão imanentes, diante de conceitos ainda indeterminados, personagens ainda no limbo, planos ainda transparentes. Qualquer pensamento só é avaliado pelos movimentos que traça, fluxos que cria, multiplicidades complexas que infinitiza. Só pode ser condenado aquele pensamento que não experimenta, não prolonga, não desterritorializa, não foge, não se relaciona com problemas de fora, não abala a confiança na arbitrariedade da língua, nem vive a gagueira e o bilinguismo dentro da própria linguagem. (CORAZZA, 2002, p. 95-96).

Foi considerando esse arcabouço metodológico que desenvolvi a dissertação, pesquisando e contemplando as especificidades dos sujeitos envolvidos e o território do cárcere, considerando os avanços já conquistados nas garantias de direitos aos privados de liberdade a partir dos documentos legais, buscando desenvolver conexões que possibilitem a proposição de novas fronteiras para organizar as ações e projetos dentro do território prisional, que visem ampliar e otimizar as garantias dos direitos dos presos.

Paulo Freire (1983, p. 43) diz: "seria uma agressiva contradição se, inacabado e consciente do inacabamento, o ser humano não se inserisse num permanente processo de esperançosa busca. Este processo é a educação.”

Considero que com a atual conjuntura nacional, faz-se premente trabalhos que reafirmem que a educação no sistema penitenciário não pode ser entendida como privilégio, benefício ou, muito menos, recompensa oferecida em troca de bom comportamento. A educação é um direito fundamental de todos, homens e mulheres, independentemente do meio em que se encontram e o caminho para reintegração e diminuição da vulnerabilidade social. 


\title{
2. BREVE TRAJETÓRIA DE EDUCAÇÃO NO CÁRCERE NO BRASIL
}

\author{
A melhor afirmação para definir o alcance da prática educativa \\ em face dos limites a que se submete é a seguinte: \\ Não podendo tudo, a prática educativa pode alguma coisa
} Paulo Freire

$\mathrm{Na}$ História da humanidade sempre estiveram presentes os sistemas de punições, que foram se transformando ao longo do tempo. Silva (2006) apresenta um copilado da representação social sobre o crime, a pena e a prisão:

\begin{abstract}
Da obra Do contrato social (1762), Jean Jacques Rousseau (1712-1778) definiu a natureza das relações contratuais que se estabelecem entre os indivíduos e entre estes e o Estado na constituição de uma sociedade e justificou a legitimidade do uso da força por parte do Estado. Cesare Beccaria (1738-1794), com sua obra. Dos delitos e das penas (1764) estabeleceu para o mundo ocidental cristão as finalidades da pena e da prisão e esta concepção prevalece ainda hoje na aplicação da legislação penal. Jeremy Benthan (1748-1832), com a obra Panóptico (1789), estabeleceu os fundamentos da arquitetura prisional e, em que pesem avanços e modernizações, os parâmetros para construção de unidades prisionais continuam os mesmos ainda hoje. Cesare Lombroso (1835-1909),como seu O homem Delinquente (1876) inaugurou a frenologia, que preconizava ser possível identificar o criminoso nato a partir de determinadas características somáticas. Estas ideias revelaram-se equivocadas e o seu desserviço foi enorme, mas sua influência no Direito Penal através do mundo e na formação de estereótipos continua em vigor até os dias de hoje. Ėmile Durkheim (1858-1917), em As regras do método sociológico (1895) definiu o crime como normal, necessário e útil a toda e qualquer sociedade e até hoje ninguém conseguiu provar o contrário. Erving Goffman (1922-1982), em Manicômios, prisões e conventos (1968), denunciou a dinâmica de organização e funcionamento da prisão como uma instituição total e os danos que ela causa aos seus internos. Por fim, Michel Foucault (1926-1984), em Vigiar e punir (1975), fez a crítica mais contundente à pena e à prisão, denunciando-as como mecanismos de controle social que atendem a interesses de classe. (SILVA, 2006, p. 06).
\end{abstract}

Durante muito tempo, o padrão de penitência era definido por penas cruéis e desumanas, não havendo até então a privação de liberdade como forma de pena, mas para a garantia de que o apenado não iria fugir e para a produção de provas por meio legitimo de tortura. O preso então aguardaria o julgamento e a pena subsequente em cárcere. "O encarceramento era um meio, não era o fim da punição. (CARVALHO FILHO, 2002, p. 43).

Com o avanço do modelo de produção capitalista, que traz em seu bojo a ascensão da burguesia, continuamos a exploração e a reprodução da desigualdade social e humana, assim novas 
vias para as correções aos apenados se configuram, abandonando a punição publicizada, com espetáculo ao público para o trancamento, o isolamento e o controle social.

No final século XVIII, começam a se configurar os primeiros projetos das penitenciárias que conhecemos hoje. Carvalho Filho (2002), explica que o surgimento da pena de privação de liberdade, foi paralelo ao surgimento do capitalismo, em que um conjunto de fatores levaram ao aumento da criminalidade com o incremento dos índices de pobreza em diversos países ${ }^{18}$.

O inglês Jeremy Bentham, que defendia a punição proporcional, colocando que a disciplina dentro dos presídios deveria ser severa, com alimentação grosseira e a vestimentas humilhantes, para assim mudar o caráter e os hábitos do delinquente, descreve o modelo "Panóptico" de instituições, em que desenha uma penitenciária "modelo", com uma estrutura circular, uma torre no centro e as celas nas bordas e onde apenas um homem vigiaria todos os prisioneiros ao mesmo tempo, sem que estes o vissem. Desenvolvem-se modelos de instituições totais, locais onde permanecem um grupo de internados, que não tem contato com o mundo exterior, vigiados, supervisionados e controlados integralmente.

Como instituição total, Foucault (2013) considera os estabelecimentos penais, que nascem enquanto prisão-aparelho, instituições disciplinares para apenados e onde se concebe uma vigilância ininterrupta sobre as pessoas privadas de liberdade, o que o autor chama de panoptismo. BENELLI, (2014, p. 66) bem coloca, que a disciplina panóptica do poder constitui o processo técnico-político

\footnotetext{
${ }^{18}$ Wacquant (2007), para refutar o discurso político da direita e da mídia, que justifica o aumento do aprisionamento por causa do aumento da criminalidade violenta, explica essa inflação permanente e acelerada pelo incremento de medidas e de leis definidamente mais punitivas. Comparado com a política penal anterior - do segundo pós-guerra até os anos 1970 -, a hiperinflação carcerária deu-se pela extensão do recurso do aprisionamento para uma série de delitos que até então não levavam à pena de prisão; também pelo aumento do tempo de duração das penas para delitos sem gravidade e pelo incremento dos castigos para os crimes violentos, com o cumprimento de penas em regimes fechados. A partir do período histórico destacado e a pretensa "guerra contra a droga", o encarceramento se aplica com enorme frequência e severidade aos pequenos consumidores e vendedores de entorpecentes, que são jogados na prisão aos milhares. Garland (1999) indica como a mídia e os partidários das políticas tipo "lei e ordem" invocam - quando acontece um crime violento - o dano causado à vítima, para criar um clima de pânico generalizado, e lograr o apoio social para a aprovação de leis penais mais severas. Conforme Anitua (2008), essas mudanças nas legislações, em termos de endurecimento penal, devem ser entendidas como produto de um "populismo punitivo", que refere a atitude dos políticos com as vistas voltadas para a velha ferramenta punitiva que oferecem a uma sociedade assustada, em uma clara demonstração de que "estão fazendo alguma coisa" pela segurança pública. No marco desta perspectiva, a extensão das sentenças, por exemplo, não dependeria tanto da natureza da ofensa senão da construção de "perfis de risco", que, seria quase suficiente para encarcerar alguém. A esse respeito, referindo-se à lógica da penalogia neoliberal, De Giorgi (2006, p. 97), diz: "As novas estratégias penais se caracterizam cada vez mais como dispositivos de gestão de risco e de repressão preventiva das populações consideradas portadoras desse risco [...]". Dessa forma, o cárcere funciona como mero depósito de grupos populacionais considerados "naturalmente" perigosos e de risco para os quais não resta outro remédio senão aplicar e reforçar técnicas de controle cada vez mais capilares e totalizadoras (KILDUFF, 2010, p. 247).
} 
universalmente difundido da coerção e enquadramento dos corpos e das populações. O iluminismo ${ }^{19}$ descobriu a liberdade e, ao mesmo tempo, inventou as disciplinas que a controlam.

Nesse modelo, GOFFMAN (1987, p. 19) observa que os participantes da equipe dirigente, que exercem o controle, tendem a sentir-se superiores e corretos; os internados tendem, pelo menos sob alguns aspectos, a sentir-se inferiores, fracos, censuráveis e culpados. O autor coloca ainda:

\begin{abstract}
Em primeiro lugar, todos os aspectos da vida são realizados no mesmo local e sob uma única autoridade. Em segundo lugar, cada fase da atividade diária é realizada na companhia imediata de um grupo relativamente grande de outras pessoas, todas elas tratadas da mesma forma e obrigadas a fazer as mesmas coisas em conjunto. Em terceiro lugar, todas as atividades diárias são rigorosamente estabelecidas em horários, pois uma atividade leva, em tempo predeterminado, à seguinte, e toda a sequência de atividades é imposta de cima, por um sistema de regras formais explícitas e um grupo de funcionários. Finalmente, as várias atividades obrigatórias são reunidas num plano racional único, supostamente planejado para atender aos objetivos oficiais da instituição." (GOFFMAN, 1987, p.17-18).
\end{abstract}

Em um cenário de idas e vindas, a partir de modelos de propostas da organização nas instituições e de literaturas diversas observamos que as instituições passam a considerar a educação como elemento fundamental na proposta de transformação dos indivíduos (FOUCAULT, 2013; MIRABETE, 1997; THOMPSON, 1976).

Programas e ações de atividades educacionais estão presentes dentre aquelas pertencentes às propostas de programas de reabilitação, no entanto, as paulatinas melhorias e retrocessos acerca dos modelos desenvolvidos para julgamentos e sentenças, caminham junto, à punição com castigos, com encarceramento. Segundo Garland (2005), os modelos estão inseridos num conjunto mais amplo de reconfigurações, tanto nas formas de se conceber e se exercer a punição, quanto nas formas de se conceber o próprio Estado, seus limites e atribuições.

Na sociedade contemporânea a crise do papel social da prisão se relaciona com a crise do Estado de Bem-Estar e da própria sociedade industrial, desde o jogo de relações entre grupos de poder e operadores do sistema, até as macros transformações sociais, culturais, políticas e econômicas que se dão no mundo ocidental moderno. Sofremos historicamente, diversas alterações que, reconfiguram o campo do controle do delito e justiça penal.

Em claro contraste com o que era a visão convencional no período anterior, atualmente é que a 'prisão funciona não mais como um mecanismo de reforma ou reabilitação, mas sim como

\footnotetext{
${ }^{19} \mathrm{O}$ movimento Iluminista pode ser entendido como uma ruptura com o passado e o início de uma fase de progresso da humanidade. Essa fase é marcada por uma revolução na ciência, nas artes, na política e na doutrina jurídica.
} 
meio de incapacitação e castigo que satisfaz a demanda política popular de retribuição e segurança pública. Os últimos anos testemunharam uma destacada reviravolta na sorte da prisão. Uma instituição com uma longa história de expectativas utópicas e tentativas periódicas de reinventar-se (...) finalmente viu sua ambição reduzida drasticamente à incapacitação e ao castigo retributivo. (...) No curso de poucas décadas deixou de ser uma instituição correcional desacreditada e decadente, para se constituir em um pilar maciço e aparentemente indispensável da ordem social contemporânea." (GARLAND, 2005, p.51)

No Brasil, além da inserção do modelo de prisão aparelho com avanço do capitalismo, temos ainda a experiência da escravidão. Koerner (2001) em o "Impossível Panóptico Tropical-Escravista" escreve que a partir da especificidade da experiência brasileira, com o avanço do capitalismo e com o fim da escravidão, os dispositivos de vigilância, de disciplinamento, de punição produzidos pelo pensamento liberal, eram ainda dilatados devido as condições objetivas e subjetivas de anos de reprodução de organização social pautada na escravidão.

Foi possível verificar em diversos textos acadêmicos, Carvalho (2002), Vasquez (2010), Onofre (2013), Salla (2017), o registro de cinco períodos históricos significativos na história da educação escolar das instituições prisionais brasileiras: o período imperial, o governo de Juscelino Kubitschek, a ditadura militar, a Constituição de 1988 e o período contemporâneo.

Os textos demonstram que o Brasil, influenciado pelo modelo europeu de punição, abordado posteriormente ainda neste item, oferta "ensinamentos" aos privados de liberdade desde a segunda metade do século XIX. Vasquez (2010) afirma que a instrução escolar à população carcerária se dá desde o Brasil Império e é citada em regulamentos penitenciários da Casa de Correção da Corte/Rio de Janeiro, Presídio de Fernando de Noronha, Casa de Correção de Porto Alegre, Colônia Correcional de Dois Reis, Casa de Correção de São Paulo entre outras instituições designadas ao apresamento.

Neste período da história das prisões no Brasil, O “controle político da nação" esteve nas
mãos de D. Pedro I e D. Pedro II entre 1822 a 1889, regido pelos princípios da Constituição
Política do Império do Brasil. Durante o segundo reinado de 1840 a 1889 o país esteve
organizado por meio dos Poderes Legislativo, Executivo, Judiciário e Moderador, sendo
marcada pela economia cafeeira, difusão da instrução pública em nível primário, secundário
e superior, construção de instituições prisionais e implantação de novos regulamentos
penitenciários, como no caso da Casa de Correção da Corte, Casa de Correção de São Paulo,
Casa de Correção de Porto Alegre e Presídio de Fernando de Noronha [...], tendo o término
do governo de D. Pedro II, quase coincidindo com a abolição da escravatura (VASQUEZ,
2010, p. 55).

Já no que se refere ao conceito "educação" nessas instituições, Vasquez (2013), apresenta regulamentos com encaminhamentos sobre o tema nas Casa de Correção da Corte, da Casa de 
Correção da Capital Federal e do Presídio de Fernando de Noronha, destacando os artigos de Decretos de 1850 e 1882:

\begin{abstract}
Art. 167. Crear-se-há logo que for possível em cada huma das divisões da Casa de Correcção huma escola, onda se ensinará aos presos a ler e a escrever, e as quatro operações de arithmetica (BRASIL, DECRETO no 678, 1850).
\end{abstract}

Art. 281. A instrucção escolar é confiada a um preceptor e dada simultaneamente aos presos, reunidos por classes na escola. [...]. Art. 285. O preceptor é ajudado pelo capellão no ensino moral, religião e regras de civilidade (BRASIl, DECRETO no 8386, 1882).

Art. 187. A instrucção escolar é confiada a um professor e dada simultaneamente aos presos reunidos por classe na escola, todos os dias uteis [...] (BRASIL, DECRETO no 3647, 1900).

Art. $7^{\circ}$ Os Capellães dirão missa diariamente, ministrarão os soccorros espirituaes, e a instrucção religiosa aos presos e habitantes do presidio, por meio de predicas e outros exercicios, e o que fôr nomeado Professor de primeiras letras, dará lições todos os dias uteis de manhã e de tarde. O menos graduado ou o mais moderno dos Capellães será Coadjutor do mais antigo. [...] Art. 14. A Professora de primeiras letras dará lições todos os dias uteis de manhã e de tarde a todas as meninas do Presidio. BRASIL, DECRETO no 3403, 1865. VASQUEZ, 2013, p. 19-68)

Assim, já se notava a presença da escola de primeiras letras nos estabelecimentos penais a partir da segunda metade do século XIX, posto que no período informavam em seus dados ao Ministérios Justiça e Negócios Interiores e da Guerra a instrução escolar, moral e religiosa que se iniciou na Casa de Correção da Corte, Penitenciária de São Paulo e Presídio de Fernando de Noronha para pessoas presas e crianças, Os dados das pessoas privadas de liberdade, eram informados aos Ministérios Justiça e Negócios Interiores e da Guerra.

Vasquez (2010) demonstra que para a organização interna dessas instituições são criadas no início do Século XX, as técnicas penitenciárias, estabelecendo a constituição de modulação de pena, correção, controle técnico da detenção, o trabalho, a educação penitenciária. Nesse modelo, diversos sujeitos, como capelães, médicos, guardas e professores, além dos apenados e seus supervisores, passam a compartilhar espaço dentro das instituições penais. Temos também, uma mudança da concepção de educação na prisão, de educação intelectual para educação integral e com sua inserção nos instrumentos do tratamento penitenciária, o surgimento da ciência penitenciária, direito penitenciário e direitos humanos. Alguns documentos nos dão um exemplo desse novo panorama, dentre eles, “As Regras Mínimas para o Tratamento de Prisioneiros" que foi elaborado no $1^{\circ}$ 
Congresso das Nações Unidas sobre Prevenção do Crime e Tratamento de Delinquentes (1955) ${ }^{20}$ e a educação escolar deste período, ministrada nas instituições carcerárias, foram definidas com as bases para uma educação integral de acordo com artigos das Normas Gerais de Regime Penitenciário do Brasil $^{21}$.

Neste último documento foram ordenados requisitos para uma educação voltada para a formação e capacitação profissional das pessoas em privação de liberdade. Essas normas, conferidas na Lei $\mathrm{n}^{\mathrm{o}} 3.274$, de dois de outubro de 1957, preveem: Artigo $1^{\circ}$, inciso XIII, "a educação moral, intelectual, física e profissional dos sentenciados".

Art. $9^{\circ} \mathrm{O}$ trabalho penitenciário (art. $1^{\circ}$, inciso IV) será racionalizado, tendo-se em conta os índices psicotécnicos de cada sentenciado. $\S 1^{\circ}$ Visando a habilitar o sentenciado ao aprendizado, ou aperfeiçoamento, de uma profissão, que lhe assegure subsistência honesta na recuperação da vida livre, atenderá o trabalho às circunstâncias ambientais do seu futuro emprêgo: meio urbano ou meio rural.

Artigo 22, tôda à educação dos sentenciados (art. $1^{\circ}$, inciso XIII), levando-se-lhes em conta os índices psicopedagógicos (art. $9^{\circ}$ ) e orientada a sua vocação na escolha de uma profissão útil, objetivará readaptá-los ao meio social. (Brasil, 1957).

Art. 23. Na educação moral dos sentenciados, infundindo-se lhes hábitos de disciplina e de ordem, também se compreendem os princípios de civismo e amor à Pátria, bem como os ensinamentos de religião, respeitada, quanto a êstes, a crença de cada qual. (VASQUEZ, 2013, p. 130)

Um ponto bastante importante para vislumbrarmos o panorama da época é revelado por Neves (2011), quando evidencia que no início do século XX, a oferta da atividade física como prática do tratamento penitenciário passa a ser utilizada como uma forma de tratamento disciplinar ao homem criminoso, já que o crime estava associado a hereditariedade, degeneração e higiene. Por isso, a atividade física era utilizada para controlar, moralizar e disciplinar o corpo biológico e social do preso. Ainda, a prática da atividade física/exercício físico passou a ser usada como uma técnica de tratamento do preso quando, se instituiu a pena privativa da liberdade $3 / 4$, aquela que restringe, com maior ou menor intensidade, a liberdade do condenado, que permanece em um determinado estabelecimento penal, por um período longo ou não, e, tem como finalidade moralizar e controlar o

20 https://www.unodc.org/documents/justice-and-prison-reform/Nelson_Mandela_Rules-P-ebook.pdf 21 http://www.planalto.gov.br/CCivil_03/leis/1950-1969/L3274.htm\#: :text=a\%20seguinte\%20Lei\%3A,Art.,corresponda $\% 20 \mathrm{o} \% 20$ tratamento\%20penitenci\%C3\%A1rio\%20adequado. 
corpo do encarcerado, sendo também considerada como proposta de concepção moderna de ressocialização.

Neves (2011) exemplifica algumas das instituições de ensino, na passagem do século XIX ao $\mathrm{XX}$, que tinham em seu programa educacional a prática da atividade física no contexto da educação penitenciária, como: Escolas de Primeiras Letras da Casa de Correção do Rio de Janeiro e Presídio de Fernando de Noronha, Escolas da Casa de Correção do Rio Grande do Sul e Penitenciária de Florianópolis. Na segunda metade do século XX, a educação penitenciária passou a ser efetivada por meio de programas educacionais do Governo Federal, a exemplo, dos Projetos Minerva e João da Silva, Educação Integrada, dos projetos e ações do Movimento de Educação Básica da CNBB, do Movimento de Educação e também o Movimento Brasileiro de Alfabetização com a participação de outras instituições e em seguida pelos cursos ofertados pelo ensino supletivo pela modalidade EJA (JULIÃO, 2007; VASQUEZ, 2010; PENNA, 2007; MOREIRA, 2016).

Ainda no período do Regime Militar (1964-1985), temos uma educação escolar marcada por repressão, mas também pelas transições sociais, políticas e culturais. Nesse período, o governo lançou por meio da Lei $\mathrm{n}^{\circ}$ 5.379, o Movimento Brasileiro de Alfabetização (MOBRAL) que tinha por objetivo a alfabetização de jovens e adultos que por alguma razão não houvessem concluído a etapa fundamental de sua escolarização (Brasil, 1967). De acordo com Lira e Araújo (2014), o método: [...] tinha como foco o ato de ler e escrever, a metodologia se assemelhava a de Paulo Freire, com codificações, cartazes com famílias silábicas, quadros, fichas, porém, não utilizava o diálogo como a proposta de Freire e não se preocupava com a formação crítica dos educandos (Lira e Araújo, 2014, p. 5). Ainda segundo Lira e Araújo (2014, p. 5), a Educação de Jovens e Adultos pela primeira vez em sua história, conta com a publicação de uma Lei.

Lei $n^{\circ} 5.379$, de 15 de dezembro 1967, provê sobre a alfabetização funcional e a educação continuada de adolescentes e adultos. Art. $1^{\circ}$ Constituem atividades prioritárias permanentes, no Ministério da Educação e Cultura, a alfabetização funcional e, principalmente, a educação continuada de adolescentes e adultos. Parágrafo único. Essas atividades em sua fase inicial atingirão os objetivos em dois períodos sucessivos de 4 (quatro) anos, o primeiro destinado a adolescentes e adultos analfabetos até 30 (trinta) anos, e o segundo, aos analfabetos de mais de 30 (trinta) anos de idade. Após êsses dois períodos, a educação continuada de adultos prosseguirá de maneira constante e sem discriminação etária. (PORTUGUÊS, 2001, p. 54). 
Ainda, sobre o tema, Português (2001) acrescenta:

[...] até o final da década de 1970, as escolas no interior das unidades prisionais regulavamse observando a organização da rede regular de ensino estadual. [...] Em 1979 cessaram as atribuições da Secretaria de Estado da Educação de manutenção da escola nas prisões. Tal interrupção ocasionou uma lacuna na realização dessas atividades, culminando na mobilização e aglutinação de instituições estranhas à educação escolar propriamente, que condensaram uma série de ações para viabilizá-las. (PORTUGUÊS, 2001, p. 54)

Esse movimento vigorou até o início de 1985 e não chegou a atingir a educação escolar ministrada nas instituições carcerárias. No entanto, o período político de regime militar no Brasil alavancou o debate sobre os direitos humanos em decorrência das inúmeras perseguições, prisões, torturas e mortes daqueles que lutaram contra o Regime. O sistema prisional brasileiro voltou a ocupar espaço nos debates públicos. Vasquez (2010) aponta que frente ao regime militar instalado entre os governos de Humberto de Alencar Castelo Branco (1964-1967) e João Batista Figueiredo (19791985), muitos problemas “esquecidos” em relação ao Código Penal e Penitenciário Brasileiro ressuscitaram nos debates políticos, resultando na reformulação de outro Código Penal com significativas alterações nas normas gerais do regimento penitenciário. Ainda segundo a autora a substituição das Normas Gerais de Regimento Penitenciário (Lei n ${ }^{\circ}$ 3.274/1957) pela Lei de Execução Penal (Lei n ${ }^{\circ}$ 7.210/1984), inaugura uma nova fase na história da execução penal do Brasil. provocando mudanças no modo de tratamento e assistência às pessoas em situação de privação de liberdade.

Art. 17. A assistência educacional compreenderá a instrução escolar e a formação profissional do preso e do internado.

Art. 18. O ensino de $1^{\circ}$ grau será obrigatório, integrando- -se no sistema escolar da Unidade Federativa.

Art. 19. O ensino profissional será ministrado em nível de iniciação ou de aperfeiçoamento técnico.

Art. 21. Em atendimento às condições locais, dotar-se-á cada estabelecimento de uma biblioteca para uso de todas as categorias de reclusos, provida de livros instrutivos, recreativos e didáticos (Brasil, 1984). ${ }^{22}$

Em relação a encaminhamentos jurídicos quanto a execução penal, temos uma primeira tentativa com relação à normatização a respeito das normas de execução penal com o Código 
Penitenciário da República, cujo projeto data do ano de 1933, mas que somente teve sua publicação em 25 de fevereiro de 1937. Em 1940, o Código Penitenciário da República ainda estava sob discussão e, com a promulgação do Código Penal no mesmo ano, foi abandonado tanto na matéria e no conteúdo.

Derivada de um projeto de lei de 1951, foi aprovada em 2 de outubro de 1957, a Lei 3.274, que dispunha sobre regras penitenciárias, entretanto não previa sanções para o descumprimento dos princípios e das regras contidas na lei. Em 1957, uma comissão de juristas apresentou ao Ministro da Justiça um anteprojeto do Código Penitenciário, porém o projeto também foi abandonado. Em 1963, Roberto Lyra redigiu um anteprojeto de um Código de Execuções Penais, que não chegou a se transformar em projeto de lei em face a eclosão do movimento político de 1964. Igualmente, em 1970, Benjamin Moraes Filho elaborou novo anteprojeto, em parceria com juristas como José Frederico Marques, José Salgado Martins e José Carlos Moreira Alves, também infrutífero.

Somente em 1981, uma comissão instituída pelo Ministro da Justiça e composta por professores como Francisco de Assis Toledo, Benjamin Moraes Filho e Miguel Reale Júnior, entre outros, elaborou o anteprojeto da nova Lei de Execução Penal e em 1983, o Presidente da República João Batista de Oliveira Figueiredo encaminhou o projeto ao Congresso Nacional, que em 11 de julho de 1984, aprovou sem alterações consideráveis a Lei no 7.210, que entrou em vigor no ano seguinte, em 13 de janeiro de 1985, juntamente com a lei que reformou a Parte Geral do Código Penal.

A lei de execução penal, em seu art. $1^{\text {o }}$, explicita: “A execução penal tem por objetivo efetivar as disposições de sentença ou decisão judicial e proporcionar condições para harmônica integração social do condenado e do internado". A lei ratificou a presença das escolas nos estabelecimentos penais ao normatizar a obrigatoriedade do ensino de 10 grau às pessoas presas e custodiadas e, do ensino profissional em nível de iniciação ou nível técnico, bem como a reorganização de bibliotecas, pois esta revogou as normas gerais do regime penitenciário. Apesar da lei de execução penal prever a assistência educacional aos privados de liberdade, não discorria sobre sua regulamentação. 
Em relação ao direito do preso a educação, o marco legal do direito à educação em prisões é supranacional, desde a adoção das Regras Mínimas para tratamento dos presos, editadas pela Organização das Nações Unidas (ONU) em 1955, garantidos na Constituição Federal de $1988^{23}$,

\begin{abstract}
Artigo 5 - $\$ \mathbf{3}^{\circ}$ Os tratados e convenções internacionais sobre direitos humanos que forem aprovados, em cada Casa do Congresso Nacional, em dois turnos, por três quintos dos votos dos respectivos membros, serão equivalentes às emendas constitucionais. (Incluído pela Emenda Constitucional $n^{\circ} 45$, de 2004) (Atos aprovados na forma deste parágrafo: DLG $\mathrm{n}^{\circ}$ 186, de 2008, DEC 6.949, de 2009, DLG 261, de 2015, DEC 9.522, de 2018).
\end{abstract}

Ainda na Constituição Federal de 1988, período de redemocratização política, é reconhecida a educação como um direito de todos. No mesmo sentido, a Lei de Diretrizes e Base da Educação Nacional, $\mathrm{n}^{\circ} 9394$ de $1996^{24}$, assegura a sujeitos até então excluídos do contexto educacional, o acesso à educação, reconhecendo a Educação Infantil, a Educação de Jovens e Adultos (EJA), a Educação Especial e o financiamento nacional em toda a Educação Básica, dentre outros aspectos.

No início do século XXI, se intensificaram as discussões sobre a educação em prisões no Brasil, pois os Estados e o Distrito Federal estavam elaborando as primeiras versões dos Planos Estaduais de Educação para os Sistemas Prisionais, o que é resultado das diretrizes nacionais para área. Para encaminhar a implementação de políticas públicas para educação penitenciária, foram organizadas audiências públicas, pesquisas e eventos científicos, com a participação de integrantes de grupos de pesquisa, comissões e sociedade civil organizada para se discutir os problemas específicos de cada Estado, visando acompanhar os desdobramentos de ações planejadas com base no "Plano Estratégico de Educação do Sistema Prisional" (BRASIL, 2011).

Nesse mesmo caminho, as Diretrizes Nacionais da EJA, aprovadas pelo Conselho Nacional de Educação (CNE), através do Parecer $n^{\circ} 11 / 2000^{25}$, preceituaram o acesso à educação de jovens e adultos, até então alijados do sistema educacional:

23 http://www.planalto.gov.br/ccivil_03/constituicao/constituicao.htm

24 http://www.planalto.gov.br/ccivil_03/leis/19394.htm

25 Ministério da Educação. Conselho Nacional de Cultura. Fonte:

http://portal.mec.gov.br/cne/arquivos/pdf/PCB11_2000.pdf 


\begin{abstract}
A função reparadora da EJA se articula com o pleito postulado por inúmeras pessoas que não tiveram uma adequada correlação idade/ano escolar em seu itinerário educacional e nem a possibilidade de prosseguimento de estudos. Neste momento a igualdade perante a lei, ponto de chegada da função reparadora, se torna um novo ponto de partida para a igualdade de oportunidades. A função equalizadora da EJA vai dar cobertura a trabalhadores e a tantos outros segmentos sociais como donas de casa, migrantes, aposentados e encarcerados. A reentrada no sistema educacional dos que tiveram uma interrupção forçada seja pela repetência ou pela evasão, seja pelas desiguais oportunidades de permanência ou outras condições adversas, deve ser saudada como uma reparação corretiva, ainda que tardia, de estruturas arcaicas, possibilitando aos indivíduos novas inserções no mundo do trabalho, na vida social, nos espaços da estética e na abertura dos canais de participação. Para tanto, são necessárias mais vagas para estes "novos" alunos e "novas" alunas, demandantes de uma nova oportunidade de equalização (MINISTÉRIO DA EDUCAÇÃO. CONSELHO NACIONAL DE CULTURA, p. 09).
\end{abstract}

Destaco ainda que, apesar da Educação para Jovens e Adultos ter avançado no que se relaciona ao acesso destes a escolarização, não ficou demarcado, em nenhum instrumento legal, que ela se estenderia a jovens e adultos privados de liberdade. Também é possível inferir que a educação nas prisões durante este período, pautava-se (1) na profissionalização para a reinserção na sociedade; (2) religião como um meio de restauração de valores; (3) ordem e amor à Pátria.

Com as pressões articuladas por entidades da sociedade civil, grupos diversos, entre eles: de direitos humanos, de educação, da pastoral carcerária, dos fóruns estaduais de EJA, intensificou-se o debate público da educação em prisões. Apontando que a oferta da educação em estabelecimentos penais se sustentava pela boa vontade dos sujeitos que gestavam as unidades, colocou-se em pauta a defesa pela implementação de políticas educacionais mais sistêmicas e ordenadas aos privados de liberdade. Nessa conjuntura efervescente, organiza-se o Projeto Educando para Liberdade, protocolo de intenções para reestruturação do sistema penitenciário desenvolvido em parceria entre os Ministérios da Educação, da Justiça e da Representação da UNESCO no Brasil, e com recursos financeiros do governo japonês. O Projeto constituiu-se em uma referência fundamental na construção de uma política pública integrada e cooperativa no âmbito das ações da Educação de Jovens e Adultos e da Administração Penitenciária, esse projeto apresentou objetivos voltados para a garantia, ampliação e fortalecimento das atividades educativas nos contextos penitenciários (UNESCO, 2006) e deu origem a uma série de iniciativas que permitiram a revisão das propostas educativas dos presídios em todas as regiões brasileiras e culminou, com a construção das Diretrizes Nacionais para a Oferta da Educação em Estabelecimentos Penais aprovadas pela Resolução n 3, de 
11 de março de 2009, do Conselho Nacional de Política Criminal e Penitenciária (CNPCP) e homologadas pelo Ministério da Educação por meio da Resolução no 2 do Conselho Nacional de Educação (CNE), de 19 de maio de 2010.

\begin{abstract}
A história do projeto remonta a algumas gestões realizadas pelo Ministério da Justiça (MJ) junto ao Ministério da Educação (MEC), no início de 2005, a fim de que fosse instituído um Grupo de Trabalho para a discussão de estratégias de fortalecimento da oferta de educação básica nos estabelecimentos penais do país (UNESCO, 2006).
\end{abstract}

A partir de oficinas, seminários estaduais e regionais e com financiamento de encontros e projetos em diversos Estados, com a participação de operadores da execução penal, educadores, universidades, igreja e organizações não governamental, gestou-se o I Seminário Nacional de Educação em Prisões, realizado em Brasília, em junho de 2006. Em 2007, foram realizados novos seminários regionais, o financiamento de projetos em alguns Estados e o II Seminário Nacional. O Projeto Educando para a Liberdade, impulsionou ações educativas, criando condições para que programas destinados à população carcerária fossem desenvolvidos e que se efetivasse uma política de educação prisional no Brasil.

O Programa Nacional de Segurança Pública com Cidadania (PRONASCI), lançado em agosto de 2007, foi o responsável pela implementação dos programas impulsionados pelo "Educando para a Liberdade", e foi à época, considerado pelo governo federal como o programa que inaugurou "[...] um novo paradigma nas políticas de segurança pública [...]” (CARREIRA, 2009, p.20), fomentando o compromisso em favor de uma política pública de educação prisional que culminou com as Diretrizes Nacionais para a Oferta de Educação nos Estabelecimentos Penais, implementando na agenda política, vários projetos, conjunturalmente bem sucedidos, tais como o Brasil Alfabetizado ${ }^{26}$; o Programa de Educação Profissional para Jovens e Adultos para Jovens e Adultos (PROEJA) ${ }^{27}$; o Exame Nacional do Ensino Médio (ENEM), ${ }^{28}$; o Programa Nacional de Inclusão de Jovens

26 Meta de promover a alfabetização de 6 mil jovens presos que não tiveram a oportunidade de escolarização ou abandonaram a escola precocemente.

27 Permitir aos detentos cursarem e concluírem o nível médio integrado a cursos profissionalizantes.

28 Preparação dos detentos para o acesso à formação universitária por meio do PROUNI ou Universidade Aberta, ambos coordenados pelo Ministério da Educação. 
$(\text { PROJOVEM })^{29}$; entre outros projetos e/ou ações que resguardavam o objetivo de estimular a instrução escolar e à formação profissional de presos.

Infelizmente, adiante, conforme pesquisa do Instituto de Estudos Socioeconômicos (INESC) em 2010, percebe-se que o Programa Nacional de Segurança Pública com Cidadania (PRONASCI) não foi eficaz:

[...] mostrara-se incapaz de resguardar suas concepções iniciais pautadas nos direitos humanos e numa visão sobre o fenômeno da violência que considerava também suas causas socioeconômicas. Das 94 ações e projetos previstos inicialmente pelo Pronasci, muitos sequer chegaram a sair do papel [...]. Além disso, o Pronasci, como outros programas sociais, está sujeito aos cortes orçamentários impostos pelas políticas econômica e fiscal do governo, o que se revela como um impedimento concreto à realização dos direitos e ao combate às desigualdades. (AGUIAR, 2011, p. 78).

O desmonte dos programas e ações do PRONASCI, foi consequência das descontinuidades e ressalvas nos investimentos financeiros, limitando-se à implantação piloto em três estados.

No entanto, foi a partir das Diretrizes Nacionais para a oferta de educação nos estabelecimentos penais, aprovadas em 2009 pelo Conselho Nacional de Política Criminal e Penitenciária (CNCP) e em 2010, pelo Conselho Nacional de Educação $(\mathrm{CNE})^{30}$, que surge a indicação de que cada Estado da Federação tenha o seu Plano Estadual de Educação nas Prisões:

É atribuição do órgão responsável pela educação nos Estados e no Distrito Federal (Secretaria de Educação ou órgão equivalente) e deverá ser realizada em articulação com os órgãos responsáveis pela sua administração penitenciária, exceto nas penitenciárias federais, cujos programas educacionais estarão sob a responsabilidade do Ministério da Educação em articulação com o Ministério da Justiça, que poderá celebrar convênios com Estados, Distrito Federal e Municípios (RESOLUÇÃO Nº 2, DE 19 DE MAIO DE 2010, p. 2).

29 Oferecer a cerca de 30 mil jovens a oportunidade de cursar o ensino fundamental

30 RESOLUÇÃO N 2, DE 19 DE MAIO DE 2010 (*) Dispõe sobre as Diretrizes Nacionais para a oferta de educação para jovens e adultos em situação de privação de liberdade nos estabelecimentos penais. Fonte:http://portal.mec.gov.br/index.php?option=com_docman\&view=download\&alias=5142-rceb002-

10\&category_slug=maio-2010-pdf\&Itemid=30192 (p. 2) 
O Decreto $n^{\circ}$ 7.626/2011, que instituiu o Plano Estratégico de Educação no Âmbito do Sistema Prisional (PEESP), trouxe a finalidade de ampliar e qualificar a oferta de educação nos estabelecimentos penais, contemplando a educação básica na modalidade de Educação de Jovens e Adultos, a educação profissional e tecnológica e a educação superior.

O Ministério da Justiça e Segurança Pública Departamento Penitenciário Nacional, Coordenação de Educação, Cultura e Esporte do DEPEN, no ano de 2020 apresenta nota técnica sobre a evolução dos índices de pessoas presas incluídas em atividades educacionais nos sistemas prisionais estaduais e sistema penitenciário federal e as metas estratégicas de atuação da Coordenação de Educação, Cultura e Esporte do DEPEN para a qualificação da política de educação no sistema prisional. A nota informa que,

Segundo o Infopen dez/2019, o Brasil ostenta o quantitativo de 748.009 pessoas no sistema penitenciário, com um total de 1435 unidades prisionais. Desse total, 65,9\% possuem sala de aula (ao menos 1) e 57,4\% possuem biblioteca. Importante destacar que a capacidade média das salas de aula em estabelecimentos prisionais é de cerca de 49.132 pessoas por turno, totalizando a capacidade total de 147.396 pessoas privadas de liberdade em sala de aula (em caso de utilização nos 3 turnos). No que concerne à participação em atividade educacional no sistema prisional brasileiro, destaca-se que 124 mil pessoas (16.53\%) estão envolvidas em atividades educacionais, sendo 79.028 mil pessoas (10,56\% do total de ppl) em atividade formal de educação básica (Educação de Jovens e Adultos) e educação profissional (cursos técnicos e cursos de formação inicial e continuada), 26.826 pessoas (3,6\% do total de ppl) estão inseridas em projetos de leitura (com direito à remição da pena pela leitura), 17.762 ( $2,4 \%$ do total de ppl) em atividades educacionais complementares (videoteca, lazer, cultura) e $0,05 \%$ (433 pessoas) em atividades esportivas relacionadas ao processo educacional. (file:///C:/Users/Marineila/Downloads/A\%20evolucao\%20dos\%20indices\%20de\%20presos \%20estudantes.pdf) 
Figura 1 - Evolução de pessoas em atividades educacionais

$19 / 05 / 2020$

SEI/MJ - 11671181 - Nota Técnica

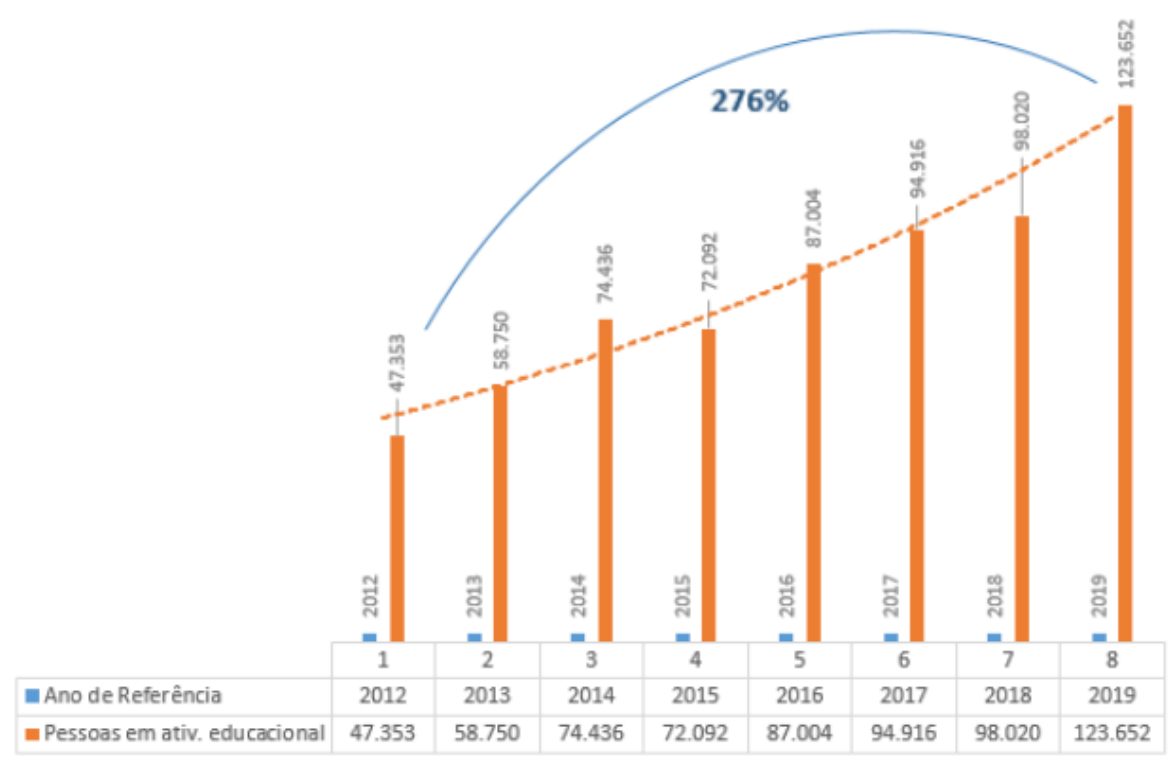

Fonte:https://www.gov.br/depen/pt-br/centrais-de-conteudo/publicacoes/notas-tecnicas/indices-envolvendocustodiados/A\%20evolucao\%20dos\%20indices\%20de\%20presos\%20estudantes.pdf/view

A nota também detalha o percentual de presos envolvidos em atividades educacionais por Unidade Federativa nos anos de 2017, 2018 e 2019.

Quadro 1 - Presos que desenvolvem atividades educacionais por Unidade Federativa (UF), nos anos de 2017, 2018 e 2019.

\begin{tabular}{|c|c|c|c|c|c|c|c|c|c|}
\hline \multirow{2}{*}{ UF } & \multicolumn{3}{|c|}{ SISDEPEN DEZ/2017 } & \multicolumn{3}{|c|}{ SISDEPEN DEZ/2018 } & \multicolumn{3}{|c|}{ SISDEPEN DEZ/2019 } \\
\hline & PRESOS & Em Atividades Educacionais & $\%$ & PRESOS & Em Atividades Educacionais & $\%$ & PRESOS & Em Atividades Educacionais & $\%$ \\
\hline $\mathrm{AL}$ & 7798 & 423 & $5,42 \%$ & 8581 & 475 & $5,54 \%$ & 9161 & 436 & $4,76 \%$ \\
\hline $\mathrm{AM}$ & 7616 & 665 & $8,73 \%$ & 9133 & 699 & $7,65 \%$ & 10890 & 852 & $7,82 \%$ \\
\hline $\mathrm{AP}$ & 2848 & 323 & $11,34 \%$ & 2963 & 25 & $0,84 \%$ & 2750 & 78 & $2,84 \%$ \\
\hline $\mathrm{BA}$ & 15103 & 3086 & $20,43 \%$ & 14896 & 3312 & $22,23 \%$ & 15108 & 3688 & $24,41 \%$ \\
\hline $\mathrm{CE}$ & 27746 & 2641 & $9,52 \%$ & 29888 & 2245 & $7,51 \%$ & 31569 & 6999 & $22,17 \%$ \\
\hline DF & 15874 & 1726 & $10,87 \%$ & 16359 & 2589 & $15,83 \%$ & 16636 & 2771 & $16,66 \%$ \\
\hline ES & 20280 & 3438 & $16,95 \%$ & 22993 & 3906 & $16,99 \%$ & 23427 & 4917 & $20,99 \%$ \\
\hline MA & 9551 & 1004 & $10,51 \%$ & 11359 & 1869 & $16,45 \%$ & 12346 & 6895 & $55,85 \%$ \\
\hline
\end{tabular}




\begin{tabular}{|c|c|c|c|c|c|c|c|c|c|}
\hline MG & 74576 & 13307 & $17,84 \%$ & 78728 & 10401 & $13,21 \%$ & 74712 & 10000 & $13,38 \%$ \\
\hline MS & 17887 & 1595 & $8,92 \%$ & 15144 & 1381 & $9,12 \%$ & 17578 & 2244 & $12,77 \%$ \\
\hline MT & 12244 & 3127 & $25,54 \%$ & 12670 & 3132 & $24,72 \%$ & 12519 & 2868 & $22,91 \%$ \\
\hline PA & 16981 & 1014 & $5,97 \%$ & 19079 & 1522 & $7,98 \%$ & 20825 & 1586 & $7,62 \%$ \\
\hline PB & 12216 & 1238 & $10,13 \%$ & 12924 & 1773 & $13,72 \%$ & 13326 & 2285 & $17,15 \%$ \\
\hline $\mathrm{PE}$ & 33085 & 6826 & $20,63 \%$ & 32188 & 9166 & $28,48 \%$ & 33641 & 11000 & $32,70 \%$ \\
\hline PI & 4495 & 393 & $8,74 \%$ & 4514 & 760 & $16,84 \%$ & 4433 & 463 & $10,44 \%$ \\
\hline $\mathrm{PR}$ & 31616 & 9761 & $30,87 \%$ & 23332 & 7878 & $33,76 \%$ & 29831 & 9527 & $31,94 \%$ \\
\hline $\mathrm{RJ}$ & 51132 & 4113 & $8,04 \%$ & 52873 & 3216 & $6,08 \%$ & 50822 & 4093 & $8,05 \%$ \\
\hline $\mathrm{RN}$ & 6696 & 399 & $5,96 \%$ & 8977 & 403 & $4,49 \%$ & 10290 & 883 & $8,58 \%$ \\
\hline RO & 11916 & 1940 & $16,28 \%$ & 12138 & 1889 & $15,56 \%$ & 13611 & 1809 & $13,29 \%$ \\
\hline $\mathrm{RR}$ & 2721 & 376 & $13,82 \%$ & 3188 & 386 & $12,11 \%$ & 3688 & 382 & $10,36 \%$ \\
\hline RS & 37432 & 2810 & $7,51 \%$ & 38888 & 2626 & $6,75 \%$ & 41189 & 2795 & $6,79 \%$ \\
\hline $\mathrm{SC}$ & 21900 & 6429 & $29,36 \%$ & 24248 & 7627 & $31,45 \%$ & 23470 & 11000 & $46,87 \%$ \\
\hline SE & 5137 & 1034 & $20,13 \%$ & 5384 & 1184 & $21,99 \%$ & 6244 & 1154 & $18,48 \%$ \\
\hline SP & 225874 & 25336 & $11,22 \%$ & 229562 & 26771 & $11,66 \%$ & 231287 & 31000 & $13,40 \%$ \\
\hline TO & 4050 & 449 & $11,09 \%$ & 4347 & 513 & $11,80 \%$ & 4481 & 586 & $13,08 \%$ \\
\hline
\end{tabular}

Fonte: Infopen

Outro dado apresentado que merece destaque é o percentual de presos por UF que desenvolvem atividades educacionais:

Quadro 2- Percentual de presos per capta em atividades educativas por estado

\begin{tabular}{|c|c|c|c|c|}
\hline \multirow{2}{*}{ RANKING } & \multirow{2}{*}{ UF } & \multicolumn{3}{|c|}{ SISDEPEN DEZ/2019 } \\
\cline { 3 - 5 } & & PRESOS & Em Atividades Educacionais & $\%$ \\
\hline 1 & MA & 12346 & 6895 & $55,85 \%$ \\
\hline 2 & SC & 23470 & 11000 & $46,87 \%$ \\
\hline 3 & PE & 33641 & 11000 & $32,70 \%$ \\
\hline 4 & PR & 29831 & 9527 & $31,94 \%$ \\
\hline 5 & BA & 15108 & 3688 & $24,41 \%$ \\
\hline 6 & MT & 12519 & 2868 & $22,91 \%$ \\
\hline 7 & CE & 31569 & 6999 & $22,17 \%$ \\
\hline 8 & ES & 23427 & 4917 & $20,99 \%$ \\
\hline 9 & SE & 6244 & 1154 & $18,48 \%$ \\
\hline 10 & PB & 13326 & 2285 & $17,15 \%$ \\
\hline 11 & DF & 16636 & 2771 & $16,66 \%$ \\
\hline
\end{tabular}




\begin{tabular}{|c|c|c|c|c|}
12 & SP & 231287 & 31000 & $13,40 \%$ \\
\hline 13 & MG & 74712 & 10000 & $13,38 \%$ \\
\hline 14 & RO & 13611 & 1809 & $13,29 \%$ \\
\hline 15 & TO & 4481 & 586 & $13,08 \%$ \\
\hline 16 & MS & 17578 & 2244 & $12,77 \%$ \\
\hline 17 & PI & 4433 & 463 & $10,44 \%$ \\
\hline 18 & RR & 3688 & 382 & $10,36 \%$ \\
\hline 19 & RN & 10290 & 883 & $8,58 \%$ \\
\hline 20 & GO & 25761 & 2155 & $8,37 \%$ \\
\hline 21 & RJ & 50822 & 4093 & $8,05 \%$ \\
\hline 22 & AM & 10890 & 852 & $7,82 \%$ \\
\hline 23 & PA & 20825 & 1586 & $7,62 \%$ \\
\hline 24 & RS & 41189 & 2795 & $6,79 \%$ \\
\hline 25 & AL & 9161 & 436 & $4,76 \%$ \\
\hline 26 & AC & 8414 & 286 & $3,40 \%$ \\
\hline 27 & AP & 2750 & 78 & $2,84 \%$ \\
\hline
\end{tabular}

Fonte: Infopen

Podemos observar que apesar de determinação das diretrizes educacionais para o cumprimento para oferta de educação em estabelecimentos prisionais, caminhou-se muito lentamente para oferta e desenvolvimento de atividades educativas e, pior, os gráficos também mostram índices de avanços do encarceramento em massa até o ano de 2020.

Carreira (2009) no "Relatoria Nacional para o Direito Humano à Educação: Educação nas Prisões Brasileiras de 2009”, documentou que a educação para pessoas presas ainda é vista como um privilégio, pois a oferta de cursos de educação básica é algo estranho no cotidiano do sistema penitenciário. Muitas vezes a educação é considerada privilégio e há ainda muita hostilidade no que tange ao trabalho educacional.

Neste contexto, muitos professores afirmaram sentir a unidade prisional como um ambiente hostil ao trabalho educacional, onde a educação se constitui, muitas vezes, em moeda de troca, pois de um lado, há os gestores e agentes penitenciários, e do outro, os encarcerados, visando à manutenção da ordem disciplinar, pois há um conflito cotidiano entre a garantia do direito à educação e o modelo vigente de prisão. Além disso, o atendimento educacional é interrompido quando circulam boatos sobre a possibilidade de motins; na ocasião de revistas; como castigo ao conjunto das pessoas presas que integram uma unidade na qual ocorreu uma rebelião, ficando à mercê do entendimento e da boa vontade de direções e dos agentes penitenciários (CARREIRA, 2009). 
Anos depois, como Supervisora de Ensino, continuamos quase no mesmo patamar descrito pela autora. É possível observar uma nítida divisão entre agentes penitenciários e profissionais da educação que se posicionam em campos completamente opostos, além de pouquíssimas propostas no que tange a avanços de políticas públicas nesta área.

\title{
2.1. Políticas de segurança pública e execução penal
}

Segundo a Constituição Federal brasileira, são direitos assegurados aos presos:

\begin{abstract}
Art. $5^{\circ}$ Todos são iguais perante a lei, sem distinção de qualquer natureza, garantindo-se aos brasileiros e aos estrangeiros residentes no País a inviolabilidade do direito à vida, à liberdade, à igualdade, à segurança e à propriedade, nos termos seguintes: III - ninguém será submetido a tortura nem a tratamento desumano ou degradante; (...) XLVIII - a pena será cumprida em estabelecimentos distintos, de acordo com a natureza do delito, a idade e o sexo do apenado; (...)

XLIX - é assegurado aos presos o respeito à integridade física e moral; (...)

L - às presidiárias serão asseguradas condições para que possam permanecer com seus filhos durante o período de amamentação; (...)

LXIII - o preso será informado de seus direitos, entre os quais o de permanecer calado, sendolhe assegurada a assistência da família e de advogado; (...)

LXXV - o Estado indenizará o condenado por erro judiciário, assim como o que ficar preso além do tempo fixado na sentença (BRASIL, 1988)
\end{abstract}

Neste liame, para evitar que fossem desrespeitados os direitos dos apenado e dar garantias àqueles que não foram atingidos pela sentença é que foi criada a Lei de Execução Penal (Lei n ${ }^{\circ} 7.210$ de 11 de julho de 1984 - LEP), que se propõe a não somente punir os apenados, mas também oferecer conhecimento dos direitos, dar um tratamento individualizado e buscar o que apresenta como ressocialização destes, recuperando-os por meio do trabalho, do estudo e de regras fundamentais de cidadania para a reintegração na sociedade. A lei de execução penal institui no artigo 41 os direitos dos presos:

I - alimentação suficiente e vestuário;

II - atribuição de trabalho e sua remuneração;

III - Previdência Social;

IV - constituição de pecúlio;

V - proporcionalidade na distribuição do tempo para o trabalho, o descanso e a recreação;

VI - exercício das atividades profissionais, intelectuais, artísticas e desportivas anteriores, desde que compatíveis com a execução da pena;

VII - assistência material, à saúde, jurídica, educacional, social e religiosa;

VIII - proteção contra qualquer forma de sensacionalismo;

IX - entrevista pessoal e reservada com o advogado;

$\mathrm{X}$ - visita do cônjuge, da companheira, de parentes e amigos em dias determinados;

XI - chamamento nominal; 
XII - igualdade de tratamento salvo quanto às exigências da individualização da pena;

XIII - audiência especial com o diretor do estabelecimento;

XIV - representação e petição a qualquer autoridade, em defesa de direito;

$\mathrm{XV}$ - contato com o mundo exterior por meio de correspondência escrita, da leitura e de outros meios de informação que não comprometam a moral e os bons costumes.

XVI - atestado de pena a cumprir, emitido anualmente, sob pena da responsabilidade da autoridade judiciária competente. (Incluído pela Lei $n^{\circ} 10.713$, de 2003)

Parágrafo único. Os direitos previstos nos incisos $\mathrm{V}, \mathrm{X}$ e XV poderão ser suspensos ou restringidos mediante ato motivado do diretor do estabelecimento. (LEI N ${ }^{0}$ 7.210, 1984)

Temos descrito claramente tanto na Constituição Federal como na Lei de Execução Penal garantias de direitos aos presos, inclusive para alguns autores a Lei de Execução Penal apresenta a preocupação por buscar a individualização da execução da pena, respeitar o preso como pessoa, como cidadão (ASSIS 2008, MIRABETE 1997, TEIXEIRA 2008). Assis (2008) ainda escreve que, “as garantias legais previstas durante a execução da pena, assim como os direitos humanos do preso estão previstos em diversos estatutos legais".

Mas, sobre a garantia dos direitos, Baratta (2004) considera que:

[...] mesmo essa visão de garantia dos direitos humanos sendo um tanto mais palpável, ainda se configura como um dever ser (grifo meu), pois na contraditória realidade nem todos podem desfrutar desses direitos, existindo uma verdadeira violência estrutural que afeta sua satisfação (BARATTA, 2004, p. 334 -338).

Concretamente, o que temos atualmente são os presídios, em sua maioria sucateados, pois além das questões concernentes aos encaminhamentos equivocados quanto a políticas de segurança pública, as prisões muitas vezes são relegadas ao abandono, superlotação, entre outros padecimentos, agravando ainda mais a crise do sistema prisional. O Estado não tem política efetiva de reajuste para o quadro lastimável em que se encontram os locais destinados ao cumprimento de pena, agravado ainda mais com o avanço do encarceramento em massa, como demonstrado no gráfico abaixo. 
Figura 2- População encarcerada do Brasil

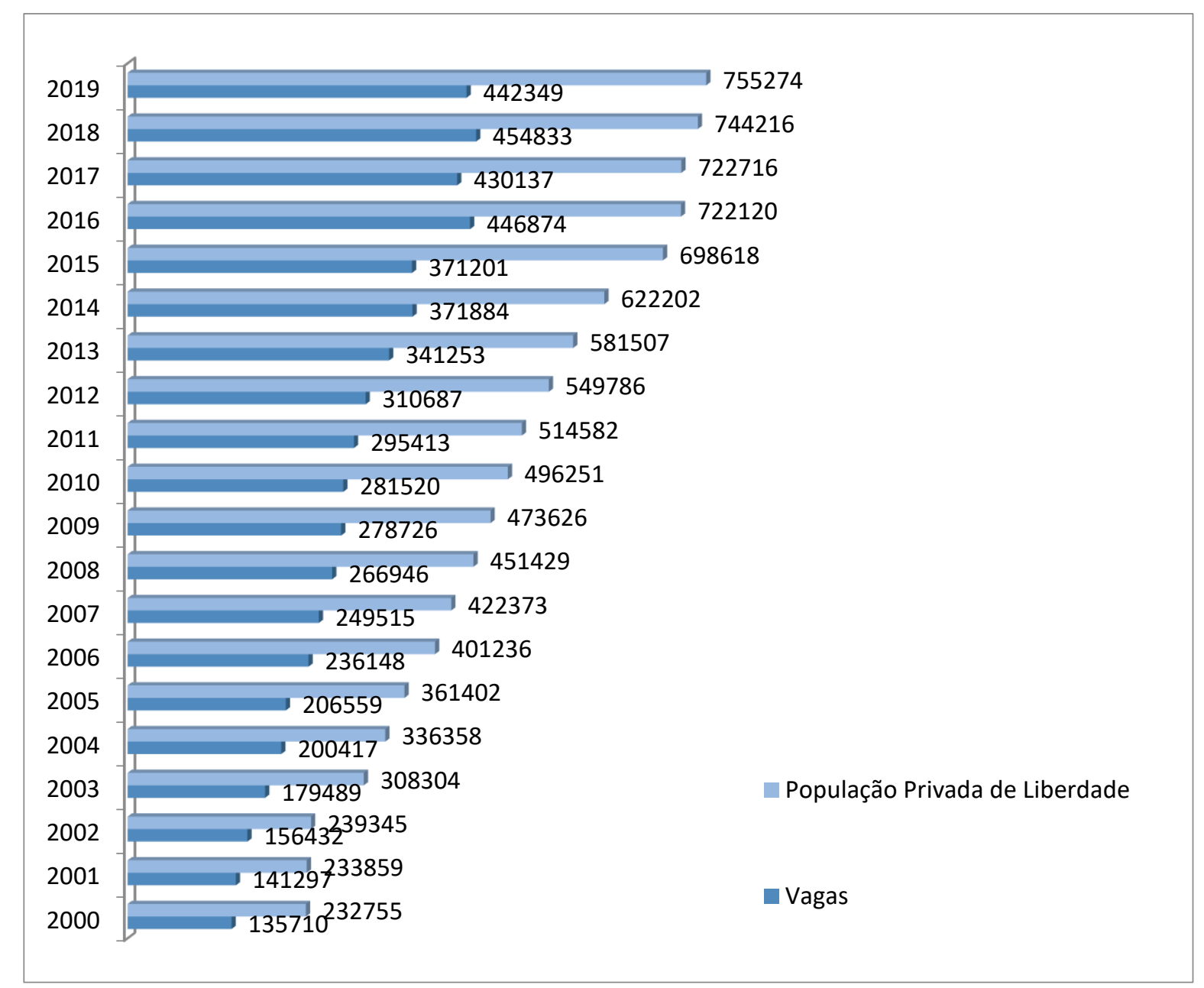

Fonte: Infopen

Os direitos mínimos constitucionais da pessoa deixam de ser respeitados e a superlotação, alimentação, assistência à saúde e educação deficitárias, são alguns exemplos de desrespeito a Constituição em espaços de privação de liberdade. Amaral (2008) explora muito bem a questão quando escreve:

Ainda que não seja tortura institucional, a população carcerária que excede mais de três vezes a capacidade oficial é, certamente, tratamento desumano ou degradante. Além da superpopulação, deficiência e racionamento no fornecimento de água e da rede de esgoto aos detentos, insuficiência de profissionais, tanto no que tange a quantidade de agentes penitenciários como para o atendimento à saúde o que acarreta entre outras dificuldades, como entrada de visitantes e de advogados (AMARAL, 2008, p. 29-41). 
Diante deste quadro de ineficiência de políticas de segurança pública, além sensação por parte da população de insegurança e do senso comum de que o aprisionamento seria solução, reproduz-se de maneira atabalhoada penas e soluções jurídicas ineficientes, que não só não solucionam o problema da criminalidade e contribuem para o agravamento do problema. Nos últimos anos, a ineficiência de políticas públicas e sociais tem determinado uma proliferação de leis penais, criminais e soluções jurídicas emergenciais que não solucionam o problema da violência e ainda levam ao aumento da população carcerária.

A histórica ineficiência da política carcerária alimenta a violência existente e contribui para o agravamento do problema social. Saliento ainda, que para a efetivação do estado democrático de direito, a segurança pública precisa ser colocada na ponta de proposições como principais políticas públicas a serem encaminhadas pelos gestores e considero que uma das mais importante está relacionada a educação no cárcere. Adorno (1996) coloca que no Brasil,

[...] a reconstrução da sociedade e do Estado democráticos, após 20 anos do regime autoritário, não foi suficientemente profunda para conter o arbítrio das agências responsáveis pelo controle da ordem pública. Não obstante as mudanças dos padrões emergentes de criminalidade urbana violenta, as políticas de segurança e justiça criminal, formuladas e implementadas pelos governos democráticos, não se diferenciaram grosso modo daquelas adotadas pelo regime autoritário. A despeito dos avanços e conquistas obtidos nos últimos anos, traços do passado autoritário revelam-se resistentes às mudanças em direção ao Estado democrático de Direito [...] (ADORNO, 1996, p. 233).

Discute-se atualmente que para o desenvolvimento da segurança pública são necessárias mudanças no modelo atual. Há no país um truísmo no que tange ao encaminhando da questão, baseando-se em políticas de repressão e doutrina punitivista, entretanto, aponto que, lado a lado ao avolumamento das políticas positivistas e de encarceramento em massa, tem-se os avanços nas discussões, estudos e proposições relativas ao encarceramento. É necessário, entretanto, ultrapassar e redefinir, em âmbito ideológico e simbólico, os conceitos e o senso comum que dão sustentação a ideologia atual: criminalidade (identificada com criminalidade de rua e da pobreza), violência (identificada com essa criminalidade) e segurança pública (identificada com segurança contra essa criminalidade).

Outra característica relevante no país é a também inexistência da prática de atuação dos municípios em temas de prevenção e controle da violência. Com relação ao conceito de atuação integrada das instituições responsáveis pela formulação e implementação de políticas setoriais, entre 
elas a educação, é importante colocar que a característica de atuação pulverizada dos diversos setores governamentais, com baixa integração, articulação e, ainda com a baixa percepção do importante papel dessas instituições setoriais em políticas de Segurança também contribui para a ineficiência. A não fragmentação demandaria um esforço coletivo, oferecendo subsídios à formulação de políticas públicas, que deveriam estar de acordo com as necessidades da comunidade. Essas iniciativas também dependem de uma mudança cultural, da assimilação definitiva desse novo paradigma e devemos entender que a diástase de práticas de políticas públicas requer, um maior tempo, esforço e transformação cultural. Saliento, que uma mudança cultural dentro da perspectiva apontada, seria inequivocamente muito profícua para o Projeto Político Pedagógico das prisões.

Sobre esse tema, a Comissão Interamericana de Direitos Humanos (CIDH) tem se pronunciado contra a militarização das forças de segurança, bem como sua privatização e ainda aponta que a natureza da instituição militar é substancialmente diferente em termos dos propósitos para os quais foram destinadas, assim como quanto à sua formação e preparação, e ainda que esse tipo de segurança carece de treinamento adequado para controlar os problemas vinculados a segurança cidadã ${ }^{31}$. Vivenciamos historicamente uma desconexão com a noção de direitos humanos, cuja defesa, proteção e garantia são de responsabilidade do Estado. Em seu relatório a CIDH (2021) exorta o Estado brasileiro a reconsiderar certas medidas e proposições em vias de adoção, tendo em vista as normas e parâmetros interamericanos de direitos humanos. (CIDH, 2021, p. 425/426).

Não se negam os avanços dos últimos anos, mas temos ainda muito a caminhar em termos de informações seguras e consistentes referentes às estatísticas criminais, à atuação e à formação das polícias, e, sobretudo, na formulação, implantação e avaliação das políticas públicas de segurança no Brasil. (SANTOS, 2011, p. 91) Tivemos, por exemplo, o reconhecimento governamental e institucional em relação à efetiva participação da sociedade na construção da política de segurança pública, que salienta um processo de fortalecimento do que apregoa nossa Constituição Federal. A instituição do Fórum Brasileiro de Segurança Pública, em 2006, e a participação da sociedade civil

\footnotetext{
${ }^{31}$ A Comissão Interamericana de Direitos Humanos produziu em 2009 um relatório sobre segurança cidadã, abordando a problemática da segurança cidadã e sua relação com os direitos humanos através do estudo de petições, casos e medidas cautelares, da adoção de relatórios sobre a situação dos direitos humanos nos Estados membros da Organização dos Estados Americanos (OEA), da preparação de relatórios temáticos, e no marco de audiências públicas convocadas durante seus períodos de sessões. Com base nas informações recebidas, a Comissão adotou a decisão de preparar um relatório temático com o objetivo de analisar a problemática e formular recomendações aos Estados Membros, orientadas a fortalecer as instituições, as leis, as políticas, os programas e as práticas para a prevenção e o controle da criminalidade e da violência no marco da segurança cidadã e dos direitos humanos. http://cidh.oas.org/pdf\%20files/seguridad\%20ciudadana\%202009\%20port.pdf
} 
nos eventos correlacionados aos Conselhos Comunitários de Segurança (CONSEG) ${ }^{32}$, realizada em 2009, evidenciam a importância da democracia para a construção de uma política de segurança pública que assegure os direitos do cidadão.

As considerações acima foram abordadas, para evidenciar que não podemos desconsiderar a conjuntura sob a qual estão inseridos nossos alunos, as problemáticas que envolvem encaminhamentos para políticas públicas, para a educação no cárcere e para a reintegração do homem preso à sociedade, um dos maiores desafios a serem enfrentados pelo Estado e pela sociedade. A implementação da execução penal objetivando a reintegração do sujeito, exige rupturas, mudanças de paradigmas, sistematização de ações pontuais combinadas a programas consistentes e duradouros, alicerçados na valorização do ser humano e levando em consideração os contextos sociais de cada cidadão. Ainda, os avanços na consolidação de uma política de segurança pública de Estado no Brasil, pautada em princípios democráticos, de solidariedade e dignidade do ser humano indicam que os desafios a serem superados tornam indispensável o exercício de uma política com fulcro nos direitos, na igualdade e na justiça social. Andrade (2013) coloca que para a mudança preconizada ocorra, o princípio vertebral a sustentar todos os demais deve ser o princípio de proteção integral de direitos humanos, erigido como objeto e limite do poder de punir e no qual o direito à segurança da pessoa, da vida e dos corpos, antes que dos bens, seja um deles.

\subsection{Precisamos falar da SARS-CoV-2}

A SARS-CoV-2 é o nome oficial dado ao novo coronavírus, abreviação de "Severe Acute Respiratory Syndrome Coronavirus 2" (síndrome respiratória aguda grave de coronavírus 2). Ele recebeu essa nomenclatura por possuir grande semelhança com o vírus SARS-CoV, agente causador da epidemia de SARS. COVID-19 quer dizer "coronavirus disease 2019" ("doença do coronavírus

\footnotetext{
32 A definição de CONSEG, se encaixa perfeitamente à orientação do art. 144 da Constituição Federal do Brasil, quando diz que a preservação da ordem pública é dever do Estado, porém, direito e responsabilidade de todos. Contudo, a ideia do Conselho Comunitário de Segurança surgiu para criar um espaço onde todos poderiam se reunir e pensar estratégias de enfrentamento dos problemas de segurança, tranquilidade e insalubridade da comunidade, orientados pela FILOSOFIA DE POLÍCIA COMUNITÁRIA. O Conselho Comunitário de Segurança é uma entidade de apoio às polícias estadual. Em outras palavras, são grupos de pessoas de uma mesma comunidade que se reúnem para discutir, planejar, analisar, e acompanhar as soluções de seus problemas, o qual se reflete na segurança pública. São meios de estreitar a relação entre comunidade e polícia, e fazer com que estas cooperem entre si. Cada CONSEG realiza reuniões ordinárias mensais, normalmente no período noturno, em imóveis de uso comunitário, segundo uma agenda definida por período anual. A Secretaria da Segurança Pública tem como representantes, em cada CONSEG, o Comandante da Polícia Militar da área e o Delegado de Polícia Titular do Distrito Policial. Sua legitimidade tem sido reconhecida pelas várias esferas de Governo e por institutos independentes, o que permite afirmar que os CONSEGs representam hoje, a mais ampla, sólida, duradoura e bem sucedida iniciativa de Polícia orientada para a comunidade em curso no Brasil.
} 
2019"), uma forma encontrada para se referir à condição sintomática de forma simplificada. A pesquisa que ora se apresenta foi desenvolvida num cenário em que o mundo passa por uma crise sanitária e humanitária em decorrência de uma pandemia ${ }^{33}$ provocada pelo COVID19, e especificamente no Brasil, posso afirmar que por uma crise política sem precedentes. Acredito que seja impossível desenvolver esta dissertação, que discorre sobre o Projeto Político Pedagógico em prisões, sem apontar algumas questões prementes a esse momento que vivemos.

A crise sanitária, em uma sociedade que se organiza sob a égide do neoliberalismo ${ }^{34}$, escancarou, ainda mais, todas as mazelas dessa sociedade. No que tange à educação e ao cárcere, aponto brevemente algumas questões conjunturais fulcrais.

Para discorrer sobre a atual conjuntura em tempos de crise social e sanitária no país, temos o recente lançamento do relatório da Situação dos Direitos Humanos no Brasil (2021) publicado pela Comissão Interamericana de Direitos Humanos (CIDH), apontando importantes pontos relativos aos direitos humanos no Brasil, dentre eles destaco: (1) a dificuldade que o Brasil tem para a concretização de garantias e práticas de direito civis, políticos, sociais, econômicos, culturais, de educação e de saúde e ainda o descumprimento desses direitos; (2) o preconceito, a dominação, a discriminação histórica racial e socioeconômica como causa da desigualdade estrutural; (3) a reiterante condição histórica de grupos afrodescendentes em situação de pobreza, de miséria, entre os desempregados e os que têm menores salários; (4) o extermínio da população marginalizada ${ }^{35}$.

33 Iniciada na província de Hubei, na China, a epidemia causada por uma nova cepa viral da família Coronaviridae (SARS-CoV-2) e que provoca a doença Covid-19 vem se disseminando rapidamente por todos os continentes. 1 No dia 11 de março de 2020, pouco mais de dois meses do seu início, a Organização Mundial da Saúde (OMS) declarou estado de pandemia da doença, confirmando-se mais de 820 mil casos e mais de 40 mil mortes em decorrência da infecção pelo SARS-CoV-2, até o dia $1^{\circ}$ de abril de 2020. 1 Até aquele momento, Estados Unidos, Itália, Espanha e China eram os países com maior número de casos, demonstrando que o vírus se expande agressivamente em locais com distintas características sociais e econômicas. O curso e a gravidade da epidemia fizeram com que muitos governos nacionais adotassem intervenções de grande intensidade, como estratégias de lockdown, a fim de conter a infecção de novos indivíduos e reduzir a sobrecarga social da doença e sua mortalidade. Tais medidas, contudo, trouxeram uma mudança brusca na vida das pessoas e da sociedade em geral. 2 Para além das questões sanitárias, o impacto da epidemia na dinâmica econômica, social, política e cultural da população mundial pôs a prova a governança dos países e agências internacionais, evidenciando os limites da globalização. Disponível em: https://www.scielosp.org/pdf/ress/2020.v29n2/e2020166/pt, pág. 01

34 Para Harvey (2008) neoliberalismo é em primeiro lugar uma teoria das práticas político-econômicas que propõe que o bem-estar humano pode ser melhor promovido liberando-se as liberdades e capacidades empreendedoras individuais no âmbito de uma estrutura institucional caracterizada por sólidos direitos a propriedade privada, livres mercados e livre comércio.

35 A Comissão considera alarmantes os altos números de homicídios de pessoas afrodescendentes no Brasil, aumentou a uma taxa de 23,1\% entre 2006 e 2016. Segundo informação obtida, 73,1\% dos 618 mil homicídios registrados no país entre 2007 e 2017, foram cometidos contra homens dessa origem étnico-racial. Preocupa ainda mais quando observada a faixa etária desses homicídios e a forma com que foram cometidos. Segundo os dados disponíveis, $78 \%$ das vítimas são 
A Comissão aborda em um dos tópicos do relatório as condições do cárcere e observa

que:

[...] além dos sérios riscos à vida e à integridade das pessoas privadas de liberdade, constituem per se situações de tratamento cruel, desumano e degradante.

Essas condições envolvem níveis alarmantes de superlotação, em sua maioria de pessoas afrodescendentes, infraestrutura precária, falta de separação entre pessoas sub judice e condenadas e notável insuficiência de agentes penitenciários. Além disso, prevalecem cuidados médicos negligentes, alimentação inadequada devido à sua escassez e baixo valor nutricional, falta de higiene, acesso inadequado à água, falta de itens essenciais, falta de programas eficazes de reintegração social e falta de tratamento diferenciado em relação aos diferentes tipos de população (209-2010).

Ainda sobre o cárcere, a CIDH (2021, p 272) dispõe análise sobre a violência seletiva ${ }^{36}$, a política de encarceramento em massa, o confinamento prolongado, a falta de contratação de agentes penitenciários, apontando que “o Estado não tem sido capaz de garantir a proteção necessária às pessoas que se encontram institucionalizadas, sejam elas públicas ou privadas. Segundo relatório do Banco Mundial ${ }^{37}$, há também nesse período pandêmico, uma polarização entre ricos e pobres com o aumento da desigualdade e de miséria vivida por parte considerável da população.

Nesse contexto de crise sanitária, para o cárcere, o Conselho Nacional de Justiça (CNJ), publica a Recomendação n ${ }^{\circ} 62$ de 2020 :

Art. 5': aos magistrados com competência sobre a execução penal que, com vistas à redução dos riscos epidemiológicos e em observância ao contexto local de disseminação do vírus, considerem as seguintes medidas: concessão de saída antecipada dos regimes fechado e semiaberto; concessão de prisão domiciliar em relação a todas as pessoas presas em cumprimento de pena em regime aberto e semiaberto; colocação em prisão domiciliar de pessoa presa com diagnóstico suspeito ou confirmado de Covid-19”. Segundo o art. $4^{\circ}$ da mesma recomendação, o CNJ recomendou "aos magistrados com competência para a fase de

jovens afrodescendentes do sexo masculino, de faixa etária entre 15 a 29 anos18. Já a taxa de mortalidade das mulheres afrodescendentes cresceu $22 \%$ entre 2006 e 2016. Soma-se a isso o fato de que, entre os anos 2015 e $2016,75 \%$ das pessoas assassinadas em intervenções realizadas por agentes das forças de segurança do Estado eram afrodescendentes 20 , crimes que na sua maioria permanecem impunes

36 os homicídios no Brasil apresentam dinâmica territorial desigual e perversa. Ao observar os números agregados, é possível notar que esses escondem o extremo contraste entre zonas extremamente perigosas e zonas extremamente seguras (inclusive em comparação com países desenvolvidos) entre (e dentro de) regiões geográficas, estados, municípios ou mesmo vizinhanças. A CIDH ressalta, portanto, a intersecção entre violência letal e outros fatores de vulnerabilidade (em especial social e econômica) da população brasileira, que se manifestam na precariedade de serviços públicos, infraestrutura e oportunidades educacionais e laborais. Pág. 437

37 Disponível em: https://news.un.org/pt/story/2020/10/1728962 
conhecimento criminal que, com vistas à redução dos riscos epidemiológicos e em observância ao contexto local de disseminação do vírus, considerem a reavaliação das prisões provisórias e a máxima excepcionalidade de novas ordens de prisão preventiva, observado o protocolo das autoridades sanitárias. (CNJ, 2020).

A recomendação serviu de apoio para alguns pedidos de soltura de pessoas pelas defensorias, como aponta a advogada e pesquisadora do Projeto Gênero e Drogas do Instituto Terra, Trabalho e Cidadania (ITTC), Cátia Kim. "Houve casos isolados de movimentações do Judiciário, mediante pedidos das defensorias públicas dos Estados e de advogadas e advogados. Muitos foram embasados na Recomendação $n^{\circ} 62$ do CNJ e também de casos específicos envolvendo mulheres gestantes e com filhos menores de 12 anos, pessoas idosas e acometidas por doenças crônicas e outras questões de saúde graves". Porém, a redução da população carcerária, especialmente do regime semiaberto, ainda é muito baixa. "Entendemos que essa redução representa um percentual muito pequeno quando observada o número global da população carcerária no Brasil, 748.009 de julho a dezembro de 2019 e 702.069 de janeiro a junho de 2020. Além disso, tal redução não indica, necessariamente, que foram aplicadas medidas alternativas ao encarceramento" ${ }^{38}$.

Para além do apontado acima, observou-se na prática, uma retrogradação de medidas e o isolamento dessa população, tais como o impedimento do acesso aos presos, a falta de informações sobre as circunstâncias em que se encontravam as unidades prisionais que, como sabemos, antes mesmo da crise sanitária provocada pela COVID 19, já se achava sob estado de barbárie. Destarte, vemos um exponencial número de contaminados e de mortes, divulgadas ${ }^{39}$ nos relatórios do $\mathrm{CNJ}^{40} \mathrm{e}$ de denúncias de descumprimentos de direitos básicos, apontando que

[...] as cadeias contemporâneas têm se constituído em verdadeiros calabouços. Superlotadas, fétidas e sem a menor condição de higiene na maioria dos casos, transformam-se facilmente em terreno fértil para a propagação de doenças, convertendo a detenção em praticamente sentença de morte. (Instituto Humanitas Unisinos, 2020, p. 276)

Sobre as mortes dentro do cárcere em consequência da COVID 19, na visão da psicóloga e mestranda em Antropologia Social pela Unicamp e integrante do Infovírus, Catarina Pedroso, é possível que haja subnotificação no número de casos de óbito e contaminados. "Por exemplo, há mais

38 https://ponte.org/coronavirus-chega-a-80-das-unidades-prisionais-de-sp-mortes-ocorreram-em-25-prisoes/

39 Há diversas fontes considerando que essas mortes podem estar subnotificadas (procurar)

40 Disponível em: https://www.cnj.jus.br/sistema-carcerario/covid-19/registros-de-contagios-obitos/ 
casos registrados de óbitos entre servidores do que entre pessoas presas, sendo que há cerca de 10 vezes mais pessoas presas do que servidores no sistema"41.

No que tange a educação, o impacto do COVID -19 foi incomensurável. Segundo a UNESCO (2021), cerca de 1,5 bilhão de estudantes e jovens em todo o planeta foram implicados com a suspensão de aulas e até março de 2021, em média, dois terços de um ano acadêmico foram perdidos $^{42}$. São inúmeras as consequências e os impactos causados na vida dos estudantes e dos pais. É importante salientar que os impactos da crise sanitária, tem implicações mais severas nos estudantes em situação de vulnerabilidade, dentre estes impactos, estão a falta de acesso as tecnologias para realização de ensino remoto, o aumento da evasão escolar, a dificuldade de acesso a aprendizagem e ao currículo. Todos esses apontamentos são vivenciados cotidianamente por mim no acompanhamento de escolas públicas e privadas, como Supervisora de Ensino.

Se a educação regular foi incalculavelmente afetada pelo COVID-19, o impacto da crise sanitária e socioeconômica nas unidades prisionais, que como já dissemos, está longe de cumprir as disposições legais, é ainda mais infausto e preocupante, pois temos a interrupção das aulas presenciais, professores das aulas regulares e dos projetos tiveram o acesso interrompidos e ainda não há estudos sobre o impacto dessas mudanças no que se refere a educação no cárcere.

Esta pesquisa, que tem como alicerce as ações e projetos desenvolvidos a partir da parceria do GEPEPRIVAÇÃO com a DECTO desde 2013, apesar de considerável levantamento de dados coletados nesses últimos anos, também padece com o surgimento da pandemia, pois a coleta de dados é interrompida a partir de março de 2020.

Temos em contrapartida, impulsionado seminários e reuniões de grupos de trabalho e pesquisa, como é o caso do GEPEPRIVAÇÃO, que passou a realizar reuniões semanais e desenvolver planos de trabalho que forneceram dados para essa pesquisa.

Neste capítulo foi possível observar o histórico de instabilidade e descontinuidade das políticas de segurança pública e de execução penal e as dificuldades de encaminhar e implementar políticas públicas para o sistema penitenciário brasileiro, que estejam pautadas nos Direitos Humanos,

41 https://ponte.org/coronavirus-chega-a-80-das-unidades-prisionais-de-sp-mortes-ocorreram-em-25-prisoes/ 42 Disponível em: https://pt.unesco.org/news/dados-da-unesco-mostram-que-em-media-dois-tercos-um-ano-academicoforam-perdidos-em-todo-o 
posto que a força do estado penal se impõe à alternativa de uma política de segurança pública pautada em ideais humanos sociais.

É preciso reconhecer que o aprisionamento de enorme contingente de pessoas agrava a situação da violência, É preciso ampliar a rede de aparelhos públicos voltados à físcalização e acompanhamento dos cumpridores de alternativas penais à prisão, que envolvem diferentes medidas, como penas restritivas de direitos, transação penal, suspensão condicional do processo, medidas protetivas de urgências, medidas cautelares diversas da prisão, conciliação, mediação e técnicas de justiça restaurativa (Pimenta, 2015), Observo ainda, que apesar de estarmos distante dos dispositivos acima expostos, tivemos sim, avanços nos últimos anos no âmbito da política de execução penal, que ainda persistem e continuam em fase de formulação e busca de efetivação. Esta dissertação busca contribuir para avanços nas garantias de políticas de reintegração do preso a partir da ampliação do conceito educacional, que será minuciado no último capítulo. 


\title{
3. O CENÁRIO DO ENCARCERAMENTO
}

\author{
"Todo calabouço é pequeno; \\ Toda a prisão é perpétua." \\ Mia Couto
}

Já pontuei que o Brasil aprisiona aproximadamente 750 mil presos, representando a terceira maior população de custodiados do planeta. Nesse cenário, é preciso levantar o perfil socioeconômico da população de encarcerados, um grupo formado hegemonicamente, por pessoas consideradas pobres, pretas ou pardas e que se encontra majoritariamente na faixa etária de 18 a $34 \operatorname{anos}^{43}$. Considero que para dissertar sobre o tema educação nas prisões, é necessário desenvolvermos algumas importantes contemplações crítico-reflexivas sobre a postura do Estado e sociedade no que diz respeito a criminalidade e encarceramento. Também acredito que seja fulcral discorrer sobre a correspondência destes com aspectos socioeconômicos brasileiros, tais como: falta de assistência social a população, desemprego, falta de oportunidades iguais para todos, miséria e desigualdade social ocasionadas, nas últimas décadas, por mudanças ocorridas no mundo do trabalho, pelo avanço das tecnologias e acumulação de lucros (HOBSBAWM, 1995). Ao observarmos a população carcerária identificamos que a maior parte dos presos é decorrente de grupos sociais marginalizados, excluídos da sociedade ativa por causa dos mecanismos de mercado que regulam o mundo do trabalho (ADORNO, 2006; SALLA, 2017).

Quando tratamos de educação no cárcere, estamos reflexionando uma política pública que se desenvolve num cenário e território com inúmeras problemáticas. Considerar o cenário do encarceramento e as especificidades que estão no bojo desse sistema é fundamental, posto que entre os deveres do Estado, como já dito, está o de se responsabilizar pela segurança pública e pelas medidas de execução penal. Apesar da importância do tema, a segurança pública no Brasil ainda está em construção e apesar de alguns avanços, caminha acompanhada de inúmeras adversidades, entraves e descaso, e ouso dizer, sempre distante do que é deveria ser princípio, a reintegração do preso à sociedade. 
Para Szabó (2018) o modelo de segurança pública além de ineficiente, é pouco inteligente, sem planejamento e monitoramento, sem avaliação de resultados, gasto eficiente dos recursos financeiros não se baseando em dados. Seja no executivo federal, seja nos executivos estaduais, não se avalia o que dá certo ou errado, desperdiçando-se recursos. Pensar em segurança pública é apenas pensar em diferentes formas de se punir e até este tempo, uma política onde só se toma uma atitude depois do crime, pois não há políticas efetivas de prevenção e de fomento à formação para os direitos e deveres e de investimento em inteligência. A segurança pública se resume a uma série de intervenções governamentais reativas, voltadas para a solução imediata de crises, sem encaminhamentos efetivos de políticas.

\begin{abstract}
$\mathrm{Na}$ ausência de reformas consistentes, o aparato de segurança e justiça criminal manteve-se, basicamente, com as mesmas estruturas e práticas institucionais desenhadas pelo regime militar de 1964 e herdeiras de políticas criminais pautadas no direito penal forte e absoluto. Os avanços nessa área foram residuais e cuidaram de dar caráter civil ao policiamento, retirando-o, como já destacado, do campo da "defesa nacional" e das forças armadas. A Constituição Federal de 1988 acabou, assim, reproduzindo aquilo que Theodomiro Dias Neto afirma como sendo a redução de políticas de segurança ao espaço da política criminal, notadamente marcada pela intervenção penal (Dias Neto, 2005: 114), num processo de reificação e supremacia de um ponto de vista criminalizador, na interpretação dos conflitos sociais; concentrador da segurança pública, no universo jurídico e policial; e deslegitimador da participação social e da contribuição de outros profissionais, que não os do campo jurídico, para a administração de conflitos. (grifos meu) (SZABO, 2018, p. 28-47).
\end{abstract}

Muitos estudos sobre a criminalização, revelam que os fatores genéticos da violência são bem mais complexos, envolvendo uma série de fatores sociais. Há meio século, quando Marx escreveu $O$ Capital, a livre concorrência era, para a maior parte dos economistas, uma lei natural. A obra de Marx, aponta uma análise teórica e histórica do capitalismo, onde a livre concorrência gera a concentração da produção, e que a referida concentração, num certo grau do seu desenvolvimento, conduz ao monopólio. A ideologia neoliberal triunfa no mundo inteiro e o extremo agravamento da opressão imperialista é um dos aspectos da situação mundial hoje. Lenine (2012) aponta a ação das oligarquias financeiras em âmbito nacional e internacional: "A supremacia do capital financeiro sobre todas as outras formas do capital significa a hegemonia dos que vivem de rendimentos e do oligarca financeiro; significa uma situação privilegiada de um pequeno número de Estados financeiramente “poderosos” em relação a todos os outros" (LENINE, 2012, p. 153). 
Neste cenário de desigualdade, os Estados Modernos foram com o tempo, desenvolvendo e aprimorando os aspectos hoje considerados fundamentais para a manutenção da ordem social de cada sociedade e de cada país. A criminalização torna-se o caminho do que está relacionado ao que é violento e perigoso para a ordem social e para sua manutenção. E ainda concedem a si mesmos, o direito de exercer a força física e de controlar a violência, o que implica um processo de criminalização de determinadas práticas, como roubar, matar, entre outras, todas definidas no Código Penal, e na criação de instituições como penitenciárias e os centros de recuperação, por exemplo, especializadas em manter sob controle todos os que não agirem de acordo com a lei. A associação entre pobreza, violência e criminalidade existe historicamente e decorre de umas das primeiras consequências do desenvolvimento do capitalismo nas sociedades ocidentais modernas.

No Brasil, a diegese histórica segue os caminhos colocados pelo sistema capitalista desde o período da colonização e num período mais recente, com a expulsão do campo de milhares de pessoas sem trabalho, que migraram para as cidades, o modo de vida urbano passou a ser associado ao perigo, às epidemias, à promiscuidade, a agressão e a criminalidade. Esse grupo de pessoas passa a ser considerado perigoso, não só porque potencialmente eram transmissoras de doenças, devido às más condições de suas moradias e à falta de higiene em que viviam, mas também porque muitos não tinham trabalho, eram desocupados que tiravam seu sustento das ruas ou de outras atividades ilícitas.

Em países como o Brasil, com alta concentração de renda e extrema desigualdade social, Zaluar (1985) explica o processo de exclusão:

A situação dos trabalhadores, onde a muito baixa remuneração do trabalho e assistência estatal limitada e ineficiente, que nunca assumiu nem a forma de organização asilar dedicada aos mais carentes - como na Inglaterra do século XIX - nem a forma do welfare system como nas nações desenvolvidas, acabaram por fazer surgir um grande contingente de trabalhadores pobres.

\section{$[\ldots]$}

A situação dos pobres numa sociedade estratificada e altamente individualista, como a capitalista, não é uma consequência de sua cultura, mas o resultado de políticas públicas que provocam uma real privação material e uma real exclusão dos pobres nos campos ocupacional, educacional e político. O que os exclui não é, portanto, o seu propalado fatalismo, desmotivação para o trabalho, apatia e resignação, nem a sua exclusão no campo educacional é consequência de uma suposta restrição no seu estoque simbólico. Sublinhar a cultura da pobreza neste caso termina por desviar a atenção das próprias relações de poder (ZALUAR, 1985, p.46). 
Ainda nesse âmbito, destaca-se a vulnerabilidade relacionada à discriminação histórica dos povos indígenas e comunidades quilombolas, que até hoje não obtiveram o direito à reparação e a viverem em suas terras ancestrais, assegurado pela Constituição brasileira. Os obstáculos à garantia do direito à terra, em ambos os casos, têm se combinado a crescentes conflitos agrários e a projetos de desenvolvimento executados sem consulta prévia, livre e informada com as comunidades afetadas, e que também integram a estrutura da experiência social brasileira de marginalização de pessoas em situação de pobreza na cidade e no campo. Essas pessoas seguem experimentando uma inclusão econômica precária e um acesso limitado a serviços públicos e à moradia, bem como, em muitos casos, sofrendo estigmatização e exclusões sistemáticas pela necessidade de migrar, de maneira forçada, para espaços que aparentemente tem mais oportunidades para suas vidas. Assim, em um quadro de extrema vulnerabilidade, muitas dessas pessoas são vítimas históricas de exclusão, de esquemas de trabalho precarizados, de falta de acesso ao mínimo necessário para sobreviverem com dignidade.

Como propostas de organização social, apresenta-se a prisão, que cumpre um papel, por meio do entendimento constituído na sociologia política. Wacquant (2003) nos mostra que a própria sustentação do argumento da nova ordem da política econômica neoliberal forjou a necessidade de uma nova razão penal, que se caracterizou pela supressão do Estado econômico, enfraquecimento do Estado social, fortalecimento e glorificação do Estado penal. O autor aponta ainda, que a finalidade da expansão do encarceramento deveria ser compreendida como um fenômeno cujas causas iriam além da punição aos criminosos, pois o sistema penal deve ser tomado como um instrumento político e só pode ser compreendido se levar-se em conta os diferentes ângulos pelos quais interfere na organização social. (WACQUANT, 2003, p. 40-41).

Wacquant (2003) nos indica três características político-econômicas do aprisionamento: a regulação do mercado de trabalho; a exclusão dos grupos étnicos e indesejados; a população pobre, encarcerada, transforma-se em novo produto no mercado. Assim, os resultados obtidos com o aprisionamento indicam como se consolidaram as legislações mais austeras, que criminalizaram as populações pauperizadas em diferentes continentes (WACQUANT, 2003.p 16). Nessa direção, as sociedades irão metamorfosear-se de modo a colocar as legislações e os dispositivos jurídicos a serviço das demandas ideológicas do período. A reforma do sistema social serve para vigiar e punir os grupos dominados por uma classe que se encontra no topo da pirâmide, mas que somente sobrevive graças ao esforço e ao sustento daqueles que estão a margem desta construção. 
É nesse contexto que vemos crescer o processo de criminalização da pobreza e observamos insistentemente, tanto no endurecimento das leis quanto no arrefecimento ou anuência da sociedade, as políticas de encarceramento. A luta por atribuir valor de humanidade e por garantir direitos à população prisional é, portanto, fundamental para assegurar o significado da primeira Regra de Mandela ${ }^{44}$ : respeito à dignidade inerente aos sujeitos em cumprimento de pena. Ainda, sob esse contexto, destaco que é preciso também, assegurar a "humanidade em comum entre presos e servidores penitenciários, pois quanto mais esses dois grupos reconhecem e observam sua humanidade em comum, mais digna e humana pode ser uma prisão" (COYLE, 2002, p.43).

\title{
3.1. Os sujeitos do cárcere
}

A pobreza está fortemente ligada ao sistema econômico. A Revolução Industrial criou diferentes classes sociais e um tipo de pobreza específica das cidades, que além de ter estimulado novas formas de julgar o comportamento dos homens, principalmente segundo os parâmetros do dinheiro e do trabalho, também cria a figura do trabalhador e, paralelamente, cria a figura do vagabundo, do delinquente, do trabalhador que não deu certo e que frequentemente esbarra na lei. Essas são as pessoas que estarão mais sujeitas à perseguição e punição. Adorno (1991), citado por Fausto (2001) expõe:

\begin{abstract}
A criminalização dos subalternos revela-se como poderoso instrumento de controle social. Manifesta-se na discriminação racial, na intolerância para com o imigrante na extrema dureza da condição feminina no rigoroso tratamento punitivo conferido à criança, na subalternidade que se materializa nos níveis baixos de instrução que beiram os limites da alfabetização e no elenco doméstico e manual das profissões em que é recrutada parcela significativa dos delinquentes. Perturbadora também a desproporção entre prisões e inquéritos, levando a crer que as primeiras constituíam mecanismo de intimidação e vigilância permanente da população urbana pobre e miserável, considerada por essa razão, potencialmente criminógena (FAUSTO, 2001, p. 13).
\end{abstract}

Assim, neste cenário de avanço do sistema capitalista, numa sociedade cada vez mais desigual, nos deparamos com um cárcere cada vez mais destinado a pessoas de extratos sociais

44 Regras de Nelson Mandela: Regras Mínimas das Nações Unidas para o Tratamento de Reclusos. https://www.unodc.org/documents/justice-and-prison-reform/Nelson_Mandela_Rules-P-ebook.pdf 
historicamente mais vulneráveis, que em liberdade não puderam aprimorar o desenvolvimento de suas potencialidades humanas, não encontraram ainda o sentido de suas vidas e não adquiriram escolarização ou profissionalização suficiente para lhes assegurar um lugar em suas comunidades, que estão sendo cada vez mais compelidas a encontrar na prisão o espaço que lhes forje o caráter e a personalidade.

A prisão que temos tem um papel que busca cada vez mais excluir da sociedade indivíduos que supostamente são criminosos e resultantes da multiplicidade de problemas do convívio social, conforme aponta Foucault (2013):

Uma coisa, com efeito, é clara: a prisão não foi primeiro uma privação de liberdade a que se teria dado em seguida uma função técnica de correção; ela foi desde o início uma "detenção legal" encarregada de um suplemento corretivo, ou ainda uma empresa de modificação dos indivíduos que a privação de liberdade permite fazer funcionar no sistema legal. Em suma, o encarceramento penal, desde o início do século XIX, recobriu ao mesmo tempo a privação de liberdade e a transformação técnica dos indivíduos (FOCAULT, 2013, p. 219).

Ainda sobre o cárcere, Foucault (2013) ressalta,

O que impressiona nesta história é não apenas a puerilidade dos exercícios de poder, mas o cinismo com que ele se exerce como poder, da maneira mais arcaica, mais pueril, mais infantil. Reduzir alguém a pão e água... Isso são coisas que nos ensinam quando somos criança. A prisão é o único lugar onde o poder pode se manifestar em estado puro, em suas dimensões mais excessivas e se justificar como poder moral. Tenho razões em punir, pois vocês sabem que é desonesto roubar, matar. O que é fascinante na prisão é que nelas o poder não se esconde, não se mascara cinicamente, se mostra como tirania levada aos mais infinitos detalhes, e, ao mesmo tempo, é puro, é inteiramente "justificado", visto que pode inteiramente se formular no interior de uma moral que serve de adorno a seu exercício: sua tirania brutal aparece então como dominação serena do Bem sobre o Mal, da ordem sobre a desordem (FOCAULT, 2013, p. 73).

Expandindo a análise, acrescento que num cenário em que as taxas de criminalidade explodem, devido à crise socioeconômica, e consequentemente, o encaminhamento de políticas mais rígidas quanto ao sentenciamento da população, os encarcerados, milhares dos quais não foram 
formalmente acusados de um crime, vivem em condições muito deploráveis ${ }^{45}$. A esse respeito, o Relator Especial do Conselho de Direitos Humanos da ONU sobre tortura e outros tratamentos ou punições cruéis, desumanos e degradantes estabeleceu que o alto grau de racismo institucional verificado no Brasil ocasiona que os afrodescendentes corram um risco significativamente maior de prisão em massa, abuso policial, tortura, maus-tratos e discriminação nas prisões (CIDH, p. 216). Ainda, de acordo com o Instituto de Pesquisa Econômica Aplicada (IPEA), a essas pessoas são proferidas sentenças mais altas pelos mesmos crimes cometidos pelo restante da população (CIDH, p. 217). A CIDH observa também que esse quadro tem implicado na afetação de distintos direitos humanos como os direitos à vida, à integridade, à liberdade e à segurança pessoal (CIDH, p. 424).

Nesse tópico ainda, coloco outro ponto fundamental para encaminhamentos pertinentes ao cumprimento do que é garantido aos apenados pelos marcos legais: a reintegração social. São necessários critérios objetivos e fundamentados juridicamente para implementação na prática da execução penal no que tange, por exemplo, aos benefícios de redução de pena e dos programas de reintegração social.

Mesmo em privação de liberdade, a pessoa continua com direitos garantidos. Isso porque a partir da restrição de liberdade, o Estado mantém a tutela sobre o seu direito de ir e vir, porém, as demais garantias sociais e individuais continuam asseguradas e é nessa perspectiva que a LEP se ancora para determinar a integração social aos custodiados e elenca os regramentos, responsabilidades institucionais e direitos dos custodiados. A efetividade da legislação se concretiza quando as determinações previstas na decisão criminal propiciam a reintegração social e são resultados da implementação adequada das assistências: material, à saúde, jurídica, educacional, social e religiosa.

Entretanto, temos inúmeros equívocos nos encaminhamentos dos benefícios de reintegração e de assistência na prisão, entre eles podemos citar: a não valorização da personalidade e demanda do preso, a assimetria de poder e de iniciativa que caracteriza a interação entre operadores e sentenciados, que culminam em um quadro autoritário e institucional inadequado à implementação das concepções pedagógicas e assistenciais.

Se pensarmos no indivíduo como um ser histórico e, portanto, inacabado e que se encontra numa relação permanente com o outro transformando o mundo e a si mesmo (Freire,1981, p.87), as ações pedagógicas no cárcere precisam reconhecer os efeitos do aprisionamento, buscando novas formas organização e de educação.

45DUDLEY, Steven; BARGENT, James. The prison dilemma of organized crime. Insight Crime.https://www.insightcrime.org/investigations/prison-dilemma-latin-america-incubators-organized-crime/, 
A educação para pessoas privadas de liberdade precisa necessariamente se caracterizar em um processo dinâmico, buscando que o aluno reformule e construa novas formas de agir e de interagir, de pensar e de se reconhecer como sujeito da sua própria história.

\subsection{A falsa dicotomia do encarceramento: punição para ressocialização}

Reafirmo que a educação é um dos direitos humanos, preconizada em declarações, tratados internacionais e legislação. A Declaração Universal dos Direitos Humanos (DUDH), de 1948, artigo 26, inciso I, preconiza: [...] toda pessoa tem direito à educação. A educação deve ser gratuita (...). O ensino elementar é obrigatório. O ensino técnico e profissional dever ser generalizado. (ONU, 2017). E há um consenso entre a maioria dos cidadãos sobre o direito a educação ser garantido a todas as pessoas. Sobre a universalização do direito a educação, Bittar (2014) coloca:

[...] constata-se que as políticas públicas, que deveriam ser efetivamente garantidoras da concretização do direito à educação, ainda se mostram insuficientes para atingir a igualdade material de todos em relação a este direito. Essa situação objetivará a constatação da violação de uma das principais características definidoras da própria natureza dos direitos humanos, qual seja, o seu caráter de universalidade. (BITTAR, 2014, p. 46)

Mas, apesar de senso comum, quando começamos a categorizar os grupos pertencentes a esse "todos tem direito a educação", começamos também a observar obstáculos para a garantia do direito a educação para "todos". Especificamente quando falamos de garantias de acesso à educação aos privados de liberdade, é necessária a afirmação sistemática e contundente desse direito, visto que existe uma ideia de que garantir acesso à educação aos privados de liberdade, seja conceder privilégio. Atualmente, apesar de muitos países participarem dos tratados internacionais e possuírem legislações nacionais que asseveram tal direito, a imensa maioria da população carcerária está longe de ter esse direito garantido, em quaisquer uma das modalidades educacional.

Há ainda, dificuldades em qualificar a educação no cárcere, visto que faltam informações e sistematização das diversas atividades desenvolvidas relacionadas a educação. Foi importante contextualizar, mesmo que brevemente, a trajetória histórica da educação no cárcere, pois como demonstrado ela tem momentos de avanços, contradições e retrocessos sistemáticos, diretamente ligados ao desenvolvimento capitalista liberal e com o Estado neoliberal contemporâneo. Há em todo seu processo histórico o enrijecimento de políticas de contenção e consequente ampliação da luta de movimentos sociais e de pessoas, para avançar no debate e na garantia de direitos a esta população 
Infelizmente temos nos deparado com uma mudança no discurso de prevenção especial positiva (reintegração social) dos últimos anos para prevenção especial negativa (neutralização, incapacitação $)^{46}$. Observamos ascender, o que os Estados chamam de reação ou enfrentamento ao terrorismo com vários países endurecendo seus regimes carcerários, com a criação de presídios de segurança máxima. A realidade prisional que temos está cada vez mais distante daquilo que é necessário para fazer cumprir as funções de reintegração social. Temos, na contramão do que coloca os tratados internacionais quanto ao direito das pessoas presas, avanço de discursos de senso comum, em que a educação para pessoas presas é percebida como um privilégio aos encarcerados e as unidades prisionais são um ambiente hostil ao projeto educacional. A educação no cárcere enfrenta inúmeros entraves conjunturais e ideológicos para efetivação e o sistema prisional brasileiro está sucateado e há muita dificuldade para garantir direitos legais.

Na luta cotidiana para a garantia de direitos aos apenados, está o direito à educação. É consenso entre muitos juristas e educadores que a educação é um direito de todos e que é preciso conceber e implementar políticas públicas em educação para atendimento especial de segmentos da população estrutural e historicamente fragilizados, entre elas, as privadas de liberdade. A educação constitui um dos modos mais significativos pelos quais o Estado e a Sociedade podem promover rompimento de ciclos de repetição de miséria e marginalização.

Há no país intensa movimentação relacionada às pautas ligadas aos direitos humanos. Profissionais de diferentes áreas, que estudaram e ou atuaram historicamente na busca pela garantia de direitos nos espaços de privação de liberdade, foram paulatinamente conquistando e garantindo direitos aos privados de liberdade, entre esses direitos está o direito à educação no cárcere. Freire observou, que uma política pública de Segurança Cidadã envolve várias dimensões, reconhecendo a multicausalidade da violência e a heterogeneidade de suas manifestações (FREIRE, 2009, p. 105106).

A busca da reintegração do sentenciado à sociedade precisa seguir e ser reiterada. Há evidências de que não se pode conseguir a reintegração social do sentenciado através do cumprimento da pena, entretanto deve-se buscá-la apesar dela. (BARATTA, 2006). Ainda, a educação prisional é primordial para promover a reintegração social, mas também, trata-se de garantir um direito humano

\footnotetext{
${ }^{46}$ CONDE, Francisco Munoz. WINFRIED, Hassemer. Introdução à Criminologia. Ed: Rio de Janeiro. Lumen Juris.2008.
} 
inalienável que todos devem ter acesso. O reconhecimento da cidadania dos privados de liberdade é o ponto de partida para a defesa de seus direitos educativos.

Acredito também, como já dito, e muito bem apontado por Souza (2008)

[...] mesmo que as novas opressões não devam fazer perder de vista as velhas opressões, a luta contra elas não pode ser feita em nome de um futuro melhor numa sociedade a construir. Pelo contrário, a emancipação porque se luta visa transformar o cotidiano das vítimas da opressão aqui e agora e não num futuro longínquo A emancipação ou começa hoje ou não começa nunca. (SOUZA, 2008, p. 259).

Ainda que esses avanços são conquistas alcançadas num caminho que tem como perspectiva o desencarceramento, como Oliveira (2017) muito bem expressa, as prisões são produtoras e reprodutoras de violências e violações sistemáticas e o horizonte deva ser, sempre, o desencarceramento das pessoas privadas de liberdade. Entretanto, diante da atual dinâmica da punição, da justiça criminal e da aplicação da lei penal, vislumbro que há um longo caminho até a efetivação do desencarceramento, de modo que a garantia de direitos já vigentes às pessoas que se encontram nas prisões deva ser perseguida como ação imediata, podendo, inclusive, contribuir para o desencarceramento (OLIVEIRA, 2017, p 22).

Diante destas considerações, acrescenta-se que o processo de estruturação da política de segurança pública exige rupturas, mudanças de paradigmas, sistematização de ações pontuais combinadas a programas consistentes e duradouros fincados, sobretudo, na valorização do ser humano sob todos os aspectos, levando em consideração os contextos sociais de cada cidadão. Os avanços na consolidação de uma política de segurança pública de Estado no Brasil, pautada em princípios democráticos, de solidariedade e dignidade do ser humano indicam que os desafios a serem superados tornam indispensável o exercício da cidadania com fulcro nos direitos de igualdade e na justiça social. 


\title{
4. EDUCAÇÃO EM CONTEXTO DE PRIVAÇÃO DE LIBERDADE: NOVOS PARADIGMAS
}

\author{
Há todo um velho mundo ainda por destruir \\ e todo um novo mundo a construir. \\ Mas nós conseguiremos, jovens amigos, não é verdade? \\ Rosa Luxemburgo
}

Como já abordado nesta dissertação, a formulação de políticas públicas para o cárcere, entre elas as educacionais, resultam de um longo período de luta político-social que contou com a participação da academia, de movimentos sociais, ONGS, sociedade civil, entre outros, engajados em demandas por garantias dos direitos e proposições de outros caminhos, contrários ao do punitivísmo ${ }^{47}$.

Do período da abertura política até o golpe de $2016^{48}$, o Brasil foi lentamente incorporando políticas educacionais para o cárcere, conquistando importantes avanços para este campo, mesmo que pontuais.

Vivemos historicamente um período de estagnação e, às vezes, retrocesso dessas parcas conquistas. Como exemplo podemos citar as persistentes mudanças e descontinuidades do Ministério da Justiça e do Conselho Nacional de Segurança Pública (CNSP) e a extinção da Secretaria de Educação Continuada, Alfabetização, Diversidade e Inclusão (SECADI) ${ }^{49}$. Um outro exemplo é a

\footnotetext{
$47 \mathrm{O}$ modelo de administração penitenciária, ainda admite infinitas formas de violência que se torna o principal fator de mediação das relações entre instituição/agentes, agentes/presos e presos/presos; elevada tolerância em relação a corrupção, não só no sentido pecuniário, mas também em relação aos valores, hábitos e costumes, que caracterizam o universo prisional como uma contracultura e a compra e venda de privilégios como técnica de empoderamento de presos e agentes, sem nenhuma correspondência no mundo real. A prevalência do binômio segurança/disciplina sobre toda e qualquer iniciativa de ressocialização tem sido apontada como o maior dos entraves à execução do trabalho da Educação, da Psicologia e do Serviço Social dentro da prisão (SILVA, 2001),

$48 \mathrm{Mal}$ deu tempo para os educadores comemorarem o Plano Nacional de Educação (2014-2024), Lei 13.005 que, entre outras metas, previa em sua meta de 20 anos a ampliação dos investimentos em educação ao patamar para $10 \%$ do PIB até 2024, novo golpe de Estado tornou letra morta as conquistas sociais, inclusive o PNE [...]. Fora do espectro conservador, é praticamente unânime a análise que o golpe de 2016 é contra a classe trabalhadora. Mais que isso, é uma contrarrevolução que mantém suas características históricas: é antinacional, antipopular, antidemocrático e próimperialista. Através do golpe garante-se a acumulação do capital monopólico internacional, com o uso crescente da repressão e da violência institucionalizada. (LOMBARDI, 2018, p. 51) In: https://marxismo21.org/wpcontent/uploads/2019/05/Ogolpede2016eaeduca\%C3\%A7\%C3\%A3onoBrasil book-3.pdf. Acesso: 30/03/2020

49 Do ponto de vista da garantia dos direitos a Secretaria de Educação Continuada, Alfabetização, Diversidade e Inclusão (SECADI) representou importante avanço ao dar visibilidade para sujeitos historicamente silenciados e excluídos do processo educacional. No entanto, a sua extinção no ano de 2016 evidencia o projeto educacional ancorado e em diálogo com a agenda política neoliberal e conservadora, que não só desconsidera todo caminho de luta e de garantias de direitos
} 
instituição da Polícia Penal como órgão responsável pela segurança dos estabelecimentos prisionais dos estados. SILVA, MARQUES (2021) apontam que,

\begin{abstract}
Em dezembro de 2019, o Congresso Nacional aprovou a Emenda Constitucional 104 que instituiu a Polícia Penal como órgão responsável pela segurança dos estabelecimentos prisionais dos estados. A medida foi comemorada pelos sindicatos dos então denominados Agentes Penitenciários, mas lamentada pelas organizações de direitos humanos e pela Educação e por algumas razões bem simples. Ainda que a categoria profissional e seus órgãos de representação tenham comemorado a iniciativa, para a Educação em Prisões isso significa um injustificável retrocesso pois uma coisa é estender o Direito à Educação a agentes penitenciários civis que, de resto, tem as mesmas origens sociais e apresentam as mesmas necessidades educacionais dos presos sob sua responsabilidade. Outra coisa muito diferente é pensar a educabilidade social de pessoas fardadas, armadas, que são treinadas para obedecer às ordens hierárquicas sem questioná-las e que, na nossa prática cotidiana, é a principal fonte de violação de direitos humanos no Brasil. (SILVA, MARQUES, 2021, p. 52).
\end{abstract}

Ressalto que a luta contra o encarceramento em massa, pelo fim do extermínio da juventude negra, pobre e periférica, pelo fim da guerra às drogas, pela desmilitarização da segurança pública, contra a tortura, entre outras, constitui-se imprescindível e urgente. Ainda enfatizo que é premissa fundamental reaproximar os direitos humanos das práticas de Estado. Propostas que tencionem garantir a implementação dos marcos legais de mudanças das políticas assistenciais, para já, são primordiais nesta luta.

O DEPEN, no ano de 2016, escreve um Modelo de Gestão para a política de Segurança Pública, apontando que modos estratégicos e operacionais são embasados pela legislação da Execução Penal e da Assistência Social, congruentes aos direitos e às políticas públicas.

A formulação de um Modelo de Gestão para a Política Prisional tem por principal desafio conceber e implantar modos estratégicos e operacionais que privilegiem o desenvolvimento das pessoas privadas de liberdade, buscando, num conjunto mais amplo de ações do DEPEN, romper com o processo crescente de encarceramento e com os ciclos individuais e coletivos de prisão - soltura - aprisionamento. Para tanto, é indispensável rever os processos de gestão e operação que vigem nas prisões. (grifo meu) (DEPEN, 2016, p. 311)

A Lei de Execução Penal estabelece em seus Art. 10 que a assistência ao preso e ao internado é dever do Estado, objetivando prevenir o crime e orientar o retorno à convivência em sociedade. São

percorridos até então, como banaliza e apaga a memória histórica dos sujeitos para os quais as ações e programas da SECADI destinavam-se. In: https://periodicos2.uesb.br/index.php/reed/article/view/8149 
elas: I Assistência material; II Assistência à saúde; III Assistência jurídica; IV Assistência educacional; V Assistência social; VI Assistência religiosa. Essa dissertação tem em seu alicerce a Assistência Educacional, já prevista na LEP e, busca indicar que a assistência educacional deve se adequar, ampliar e se tornar protagonista das políticas de formação para o atendimento, a convivência e a reintegração das pessoas privadas de liberdade.

Apresento nos próximos parágrafos um resumo do modelo de assistências na atual forma da Lei de Execução Penal ${ }^{50}$, e começo a apresentar indicação de reorganização possível para que, conforme apontado em relatório do DEPEN, avancemos concretamente na concepção de propostas e implantação de modelos operacionais visando a emancipação das pessoas privadas de liberdade:

1. Assistência Educacional: SEÇÃO V, Da Assistência Educacional: Art. 17. A assistência educacional compreenderá a instrução escolar e a formação profissional do preso e do internado. Art. 18. O ensino de $1^{\circ}$ grau será obrigatório, integrando- se no sistema escolar da Unidade Federativa. Art. 18A. O ensino médio, regular ou supletivo, com formação geral ou educação profissional de nível médio, será implantado nos presídios, em obediência ao preceito constitucional de sua universalização. $§ 10 \mathrm{O}$ ensino ministrado aos presos e presas integrar-se-á ao sistema estadual e municipal de ensino e será mantido, administrativa e financeiramente, com o apoio da União, não só com os recursos destinados à educação, mas pelo sistema estadual de justiça ou administração penitenciária. $\S 2$ o Os sistemas de ensino oferecerão aos presos e às presas cursos supletivos de educação de jovens e adultos. § 3o A União, os Estados, os Municípios e o Distrito Federal incluirão em seus programas de educação à distância e de utilização de novas tecnologias de ensino, o atendimento aos presos e às presas. Art. 19. O ensino profissional será ministrado em nível de iniciação ou de aperfeiçoamento técnico. Parágrafo único. A mulher condenada terá ensino profissional adequado à sua condição. 84 Art. 20. As atividades educacionais podem ser objeto de convênio com entidades públicas ou particulares, que instalem escolas ou ofereçam cursos especializados. Art. 21. Em atendimento às condições locais, dotar-se-á cada estabelecimento de uma biblioteca, para uso de todas as categorias de reclusos, provida de livros instrutivos, recreativos e didáticos. Art. 21A. O censo penitenciário deverá apurar: I o nível de escolaridade dos presos e das presas; II a existência de cursos nos níveis fundamental e médio e o número de presos e presas atendidos; III a implementação de cursos profissionais em nível de iniciação ou aperfeiçoamento

\footnotetext{
${ }^{50}$ Referência: http://www.planalto.gov.br/ccivil_03/leis/17210.htm. Acesso: 04/03/2020
} 
técnico e o número de presos e presas atendidos; IV a existência de bibliotecas e as condições de seu acervo; V outros dados relevantes para o aprimoramento educacional de presos e presas.

2. Assistência material: não é detalhada no texto legal e não está prevista nas demais normativas da assistência social, como Lei Orgânica da Assistência Social (Lei 8.742, de 1993), a Política Nacional da Assistência Social (Resolução CNAS No 145, de 15 de outubro de 2004) e o Sistema Único de Assistência Social (CNAS Norma Operacional Básica, aprovada em 14 de julho de 2005);

3. Assistência à Saúde: SEÇÃO III, Da Assistência à Saúde Art. 14. A assistência à saúde do preso e do internado de caráter preventivo e curativo, compreenderá atendimento médico, farmacêutico e odontológico. $\S 1^{\circ}$ (Vetado). $§ 2^{\circ}$ Quando o estabelecimento penal não estiver aparelhado para prover a assistência médica necessária, esta será prestada em outro local, mediante autorização da direção do estabelecimento. § 3o Será assegurado acompanhamento médico à mulher, principalmente no pré-natal e no pós-parto, extensivo ao recém-nascido;

4. Assistência Jurídica: SEÇÃO IV Da Assistência Jurídica Art. 15. A assistência jurídica é destinada aos presos e aos internados sem recursos financeiros para constituir advogado. Art. 16. As Unidades da Federação deverão ter serviços de assistência jurídica, integral e gratuita, pela Defensoria Pública, dentro e fora dos estabelecimentos penais. § 1o As Unidades da Federação deverão prestar auxílio estrutural, pessoal e material à Defensoria Pública, no exercício de suas funções, dentro e fora dos estabelecimentos penais. $\S 20$ Em todos os estabelecimentos penais, haverá local apropriado destinado ao atendimento pelo Defensor Público. § 3o Fora dos estabelecimentos penais, serão implementados Núcleos Especializados da Defensoria Pública para a prestação de assistência jurídica integral e gratuita aos réus, sentenciados em liberdade, egressos e seus familiares, sem recursos financeiros para constituir advogado.

5. Assistência Social: SEÇÃO VI, Da Assistência Social, Art. 22 e tem por finalidade amparar o preso e o internado e prepará-los para o retorno à liberdade. Art. 23. Incumbe ao serviço de assistência social: I conhecer os resultados dos diagnósticos ou exames; II relatar, por escrito, ao Diretor do estabelecimento, os problemas e as dificuldades enfrentadas pelo assistido; III acompanhar o resultado das permissões de saídas e das saídas temporárias; IV promover, no estabelecimento, pelos meios disponíveis, a recreação; V promover a orientação do assistido, na fase final do cumprimento da pena, e do liberando, de modo a facilitar o seu retorno à liberdade; VI providenciar 
a obtenção de documentos, dos benefícios da Previdência Social e do seguro por acidente no trabalho; VII orientar e amparar, quando necessário, a família do preso, do internado e da vítima.

7. Assistência religiosa: SEÇÃO VII, Da Assistência Religiosa Art. 24. A assistência religiosa, com liberdade de culto, será prestada aos presos e aos internados, permitindo-lhes a participação nos serviços organizados no estabelecimento penal, bem como a posse de livros de instrução religiosa. $\S 1^{\circ}$ No estabelecimento haverá local apropriado para os cultos religiosos. $\S 2^{\circ}$ Nenhum preso ou internado poderá ser obrigado a participar de atividade religiosa.

6. Trabalho: CAPÍTULO III, Do Trabalho, SEÇÃO I: Art. 28. O trabalho do condenado, como dever social e condição de dignidade humana, terá finalidade educativa e produtiva. $\S 1^{\circ}$ Aplicam-se à organização e aos métodos de trabalho as precauções relativas à segurança e à higiene. $\S 2^{\circ} \mathrm{O}$ trabalho do preso não está sujeito ao regime da Consolidação das Leis do Trabalho. Art. 29. O trabalho do preso será remunerado, mediante prévia tabela, não podendo ser inferior a 3/4 (três quartos) do salário-mínimo. $\S 1^{\circ} \mathrm{O}$ produto da remuneração pelo trabalho deverá atender: a) à indenização dos danos causados pelo crime, desde que determinados judicialmente e não reparados por outros meios; b) à assistência à família; c) a pequenas despesas pessoais; d) ao ressarcimento ao Estado das despesas realizadas com a manutenção do condenado, em proporção a ser fixada e sem prejuízo da destinação prevista nas letras anteriores. $\S 2^{\circ}$ Ressalvadas outras aplicações legais, será depositada a parte restante para constituição do pecúlio, em Caderneta de Poupança, que será entregue ao condenado quando posto em liberdade. Art. 30. As tarefas executadas como prestação de serviço à comunidade não serão remuneradas.

SILVA, MARQUES (2021) colocam que juridicamente não há definições precisas e definitivas quanto à superveniência de um Direito Penitenciário ou de um Direito Educacional, que nos parece seria o campo adequado para a discussão quanto às intersecções entre o exercício do direito da educação de pessoas privadas da liberdade e das regras da execução penal vigentes em estabelecimentos penais. Devemos pensar na intersecção entre educação e execução penal, com asserções que gerem impactos positivos.

Para a Educação, todas as relações devem ser pautadas pelo convívio com confiança entre as partes e o interesse em ser conduzido pelos caminhos do conhecimento, da descoberta e da liberdade. A educação deve ser a mentora de avanços e transformação do cárcere e a primeira proposta é transformar as assistências em Educação. 
Assim, o arquétipo assistencialista inscrito nos artigos 10 e 11 da Lei de Execução Penal, deve ser substituído por protótipos que sejam organizados da seguinte forma:

Tabela 1- Execução Penal

$\begin{array}{cl}\text { Execução Penal } \\ \text { I. } & \text { Material } \\ \text { II. } & \text { Saúde } \\ \text { III. } & \text { Jurídica } \\ \text { IV. } & \text { Educacional } \\ \text { V. } & \text { Social } \\ \text { VI. } & \text { Religiosa }\end{array}$

Organização Modelo PPP das prisões

Educação Patrimonial

Educação para a saúde

Educação para os Direitos

Centro Orientador de todas as assistências

Educação para a cidadania

Educação para os valores humanos

Fonte: Elaborada pela autora

O quadro propõe uma reorientação da atuação dos respectivos profissionais e de suas ciências para, efetivamente, contribuírem na garantia dos direitos e reabilitação do preso, levando assim, a mudança cultural de um território em que atualmente temos lideranças exercida pelos mais fortes, mais violentos ou com maior coleção de crimes cometidos, onde prevalece o medo, para um lugar onde a educação, transforme as relações e a vida de todos os indivíduos, paulatinamente. A Educação é o meio para desenvolver a capacidade do preso no caminho de análise de conjuntura, de desenvolvimento de competências, de argumentação e, por fim, de fomentar o senso crítico necessário para a tomada de posturas e de decisões que sejam pertinentes aos objetivos, tangentes ao território prisional e ao próprio indivíduo.

A assistência para a cidadania (Social) ao preso é o campo que deveria fazer a integração das políticas prisionais. Na construção do PPPprisões, a assistência para a cidadania deve ser aliada aos encaminhamentos pertinentes quanto a obter documentação e principalmente conhecer, relatar, acompanhar, orientar os presos.

Ainda no campo das assistências, temos o trabalho como outro importante condicionante para as proposições do PPPprisões. SILVA, MARQUES (2021) apontam que quando cruzados dados de escolaridade e de trabalho, fica evidente que os presos com baixa escolarização são os que mais constantemente optam pelo trabalho em detrimento da Educação. A proposta de Educação precisa 
considerar a relação trabalho e educação, possibilitada pelo conceito de "qualificação pelo trabalho" enunciado no Artigo 27, Inciso III, combinado com o Artigo 37, $\S 2^{\circ}$ da LDB que autoriza, inclusive, o reconhecimento de conhecimentos e habilidades adquiridos por meios informais.

Figura 3 - Percentual de Participantes

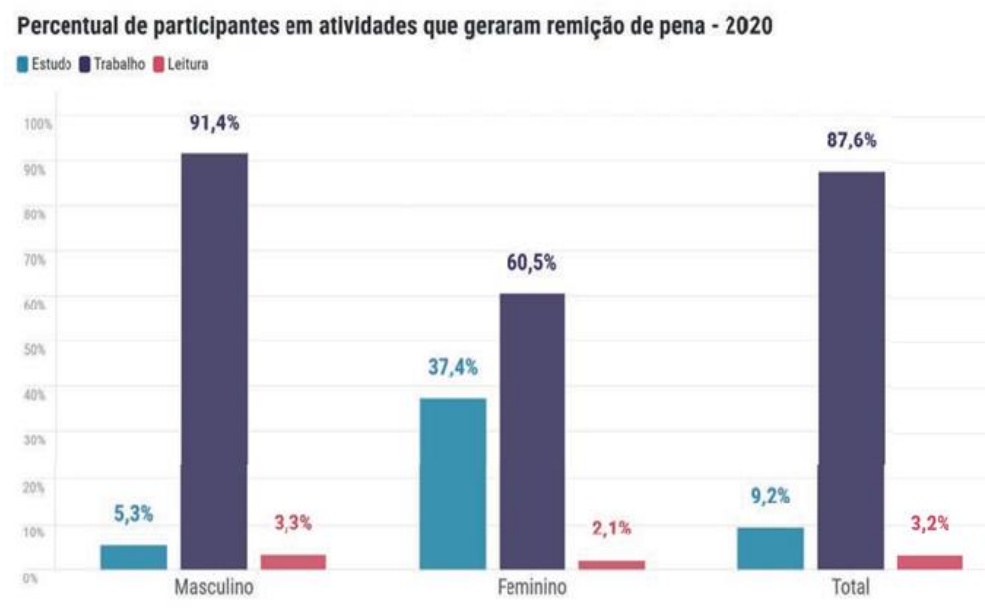

Fonte:https://acaoeducativa.org.br/publicacoes/diagnostico-de-praticas-de-educacao-nao-formal-no-sistemaprisionaldo-brasil/

Mais um exemplo, trazido por SILVA, MARQUES (2021) é a assistência à saúde. Explorando possibilidade previstas em artigos da LDB, os presos que possuem o Ensino Médio Completo podem se beneficiar da Educação Profissional, para aprendizagem de uma profissão de nível técnico, como são os casos dos monitores de Educação ( $\$ 2^{\circ}$ do Artigo $9^{\circ}$ das Diretrizes) e do Agente Prisional de Saúde (Art. $9^{\circ}$ da Portaria Interministerial 1777, de 9.9.2003 que institucionaliza o Plano Nacional de Saúde no Sistema Penitenciário). Este Plano prevê a qualificação profissional de pelo menos 5\% dos presos como Agentes Prisionais de Saúde, com formação equivalente ao do Agente Comunitário de Saúde. Somente o uso destes dois dispositivos possibilita formar, de imediato, 25 mil presos para ajudar a enfrentar os graves problemas de saúde no sistema penitenciário. Usada a mesma proporção para formação de presos como monitores de Educação, seriam outros 25 mil auxiliares para os profissionais da Educação.

Dadas as características que fazem com que a Saúde e a Educação possuam alto valor agregado na reintegração e que os presos possuem, de modo geral, uma boa representação social destas profissões, mesmo quando exercida por outros presos, estas são duas profissões sociais de nível 
técnico capazes de impactar positivamente a cultura prisional, inclusive na formação de lideranças positivas dentre a população prisional. (SILVA, MARQUES, 2021, p. 56)

Ressalto que considero todas os modelos de assistências apresentadas nesse item como atinentes a concepção de PPPprisões e das ações propostas com vistas a desenvolver projetos educacionais no território prisional, já que acredito que o desenvolvimento, implementação e envolvimento entre elas trará avanços no que se refere a organização e reintegração, minimizando o que está colocado para a população carcerária e avançando com propostas de bases conceituais e operacionais para superação deste quadro de inviabilidades das políticas assistenciais existente atualmente.

Ainda hoje, todos os profissionais que prestam as assistências e os serviços estipulados pela Lei de Execução Penal ${ }^{51}$ são funcionários do Estado, que têm vivências, experiencias, aprendizagens, formação técnica, voltadas a aplicabilidade do que indica a LEP. Para além das idiossincrasias de cada assistência, a conjunção de conhecimentos e de profissionais de diversas áreas de atuação em um mesmo campo de trabalho possibilita configurar uma comunidade científica. Thomas Kuhn, (1998) explica que

Uma comunidade científica é formada pelos praticantes de uma especialidade científica. Estes foram submetidos a uma iniciação profissional e a uma educação similares, numa extensão sem paralelo na maioria das outras disciplinas. Neste processo, absorveram a mesma literatura técnica e retiraram dela muitas das mesmas lições. (KUHN, 1998, p. 220).

As assistências são pontos fulcrais para o desenvolvimento da proposta de PPP abordada nessa dissertação, posto que ao organizar pedagogicamente as inúmeras ações desenvolvidas nos territórios prisionais, a partir das demandas de cumprimentos legais das propostas assistenciais, podemos avançar na garantia de direitos, na superação de algumas questões que são próprias e específicas do sistema penitenciário e na reintegração social.

Concebo que a educação como princípio organizador das múltiplas formas de sociabilidade humana, gerando valores e relações, caminhos de emancipação e de convivência pode ser um grande motor propulsor de mudanças da forma de conceber o território prisional ao considerar e colocar os

51 Excetuando-se a assistência religiosa 
processos educativos como fomentadores, estruturantes e condutores das relações e das ações que se pautam no território. Como bem aponta Onofre (2013, p. 55), devemos conceber que a educação possui funções socializadoras, que permitem a construção de formas seguras, saudáveis e dignas de convívio, diferentemente das tentações de adestramento que tanto caracterizam a história da educação nas prisões brasileiras.

Construir o PPP das prisões requer o entendimento de que as assistências devem encaminhar respostas: como fazer para que todos os profissionais que trabalham na prisão assumam as tarefas de Educação e de reabilitação do preso para o convício social? Como fazer para que todas as ações e atividades desenvolvidas na prisão durante o cumprimento da sentença se constituam em verdadeiras ações pedagógicas com vistas ao cumprimento da pena com dignidade, que culmine na reintegração social e cidadã?

\subsection{Projeto político pedagógico, uma conquista da Educação brasileira}

Começo este capítulo endossando que os debates, as indicações e finalmente as proposições de políticas públicas que referendem e avancem na implementação da garantia de direitos, tanto do ponto de vista legal, quanto da execução das mesmas, são absolutamente necessárias, não só para minimizar os efeitos nefastos que o neoliberalismo causa aos que estão à margem do sistema, como também, para avançar e abrir fissuras em um sistema político e econômico que não só se encontra fechado para a políticas ligadas a igualdade social, mas que também se alimenta dessas desigualdades. Paulo Freire declara "na medida em que, para dominar, se esforçam por deter a ânsia da busca, a inquietação, o poder de criar, que caracterizam a vida, os opressores matam a vida." (FREIRE, 1987, p.47). Tendo a exclusão, o abandono e a morte como caminho cotidiano, não temos outra opção senão o enfrentamento e a arma dos educadores é a proposição de políticas que caminhem para a transformação dessa sociedade desigual e que busquem nos manter vivos para cotidianamente implementar ações que suplantem essa estrutura. Ainda em Freire:

[...] a educação teria de ser, acima de tudo, uma tentativa constante de mudanças de atitude. De criação de disposições democráticas através da qual se substituíssem nos brasileiros antigos e culturológicos hábitos de passividade, por novos hábitos de participação e ingerência, de acordo com o novo clima da fase de transição. (FREIRE, 2009, p. 101). 
HOLLOWAY, nos aponta que na conjuntura capitalista contemporânea, o método da fissura é dialético, não como fluxo organizado de tese, antítese e síntese, mas como uma dialética negativa, uma dialética da inadequação. [...] Queremos entender a força de nossa inadequação, queremos saber como o repetido golpear de nossa cabeça contra a parede a fará desabar. (HOLLOWAY, 2013, p.39).

Em toda sua história passada, as finalidades da educação no Brasil, estavam diretamente ligadas aos interesses da elite. Nosso país perversamente "desenvolve-se", "mantendo o sistema de educação das elites fundamentalmente fechada às classes populares” (Teixeira, 2009, p. 29) e até o início do século XX, a educação pública servia a uma pequena parcela da população que precisava se preparar para assumir posições de destaque, que exigiam um alto nível de escolarização. A escola referendava assim, os privilégios da elite brasileira.

A partir da década de 60, movimentos políticos, sociais, culturais e de educação popular começam a surgir, impulsionando lutas para a democratização da sociedade brasileira e apontando a educação como uma nova forma de se buscar melhorar a qualidade de vida para a população. Outro fator que alavancou o incentivo de maior acesso das classes populares a educação foi o crescimento do mercado de trabalho, que exigia mão de obra qualificada.

Esse momento de luta pela difusão da escola pública que surgiu, a partir da década de 60, é apontado por Freire como fase de transição, que tem como proposta a democratização da educação, buscando tirar as pessoas da condição de objeto e levá-las para a condição de sujeito, sendo protagonista dessa renovação. Freire (2009) aponta que, como sujeitos, e não como objetos, os homens se refazem, se melhoram pelo diálogo, têm a oportunidade de, em discussões com outros seres, participar. O Projeto Político Pedagógico é um documento que possui importância histórica no contexto educacional brasileiro, pois surge na esteira das reformas que aconteceram no Brasil.

A década de 1980, período em que a educação e a economia brasileira eram caóticas, foi a época em que os governos de oposição, aos poucos, foram delineando uma política educacional contrária a que fora imposta pelos governos militares. Segundo Shiroma, Moraes e Evangelista (2007, p.37) à época, $60 \%$ da população brasileira vivia abaixo da linha da pobreza; $50 \%$ das crianças repetiam ou eram excluídas ao longo da $1^{\mathrm{a}}$ série do $1^{\circ}$ grau; $30 \%$ das crianças estavam fora da escola. Além disso, 8 milhões de crianças no $1^{\circ}$ grau tinham mais de 14 anos, 60\% das matrículas concentravam-se nas três primeiras séries que reuniam $73 \%$ das reprovações. Ainda, conforme (Shiroma, 2007, p.65) "foi na campanha para o primeiro mandato de Fernando Henrique Cardoso que 
a educação foi colocada como uma das cinco metas prioritárias, destacando seu papel econômico como base do novo estilo de desenvolvimento".

A próxima década, de 1990, foi marcada, então, por expressiva ampliação da produção acadêmica/científica que, sem as restrições da ditadura, foi amplamente divulgada por dezenas de revistas de educação, por livros publicados na área educacional, pelo reconhecimento da comunidade cientifica representada pela Sociedade Brasileira para o Progresso da Ciência (SBPC) e pelas agências federais e estaduais de fomento à pesquisa e ao ensino, pelo surgimento da União Nacional dos Dirigentes Municipais (UNDIME), criada sob a tutela do MEC. Outro ponto importante na época foi a descentralização do ensino de primeiro grau, sob condições que concretizam o marco inicial de negociação em favor da autonomia dos municípios acerca da educação. Esse marco representa o processo de construção das políticas públicas que vão legitimar a elaboração do Projeto PolíticoPedagógico das escolas brasileiras, por meio da LDB n9394/96.

Libâneo, Oliveira e Toschi (2009, p.178) colocam que “o Projeto Político Pedagógico (PPP) é proposto com o objetivo de descentralizar e democratizar a tomada de decisões pedagógicas, jurídicas e organizacionais na escola, buscando maior participação dos agentes escolares". A partir do advento da LDB é viabilizada a autonomia da escola em construir e efetivar sua proposta educativa, como uma exigência legal que cabe a escola executar.

Assim, a conquista da Constituição Federal do Brasil de 1988 e referendada pela Lei de Diretrizes e Bases da Educação Nacional (LDBEN) de 1996, que preconiza em seu artigo 12 que "os estabelecimentos de ensino respeitando as normas comuns e as do seu sistema de ensino terão a incumbência de elaborar e executar sua proposta pedagógica" e em seu artigo 15, concede às escolas autonomia pedagógica, administrativa e de gestão financeira, estabelece a gestão democrática do ensino público, como um dos princípios que deve consolidar a Educação Nacional e, consequentemente, o surgimento do Projeto Político Pedagógico, do conceito de autonomia didático pedagógica e das instituições auxiliares ${ }^{52}$, oferecendo liberdade às escolas na elaboração da sua organização e no encaminhamento de seus projetos.

\footnotetext{
${ }^{52}$ A gestão democrática oportuniza a implementação de novos processos de organização e gestão, baseados em uma dinâmica que favoreça os processos coletivos e participativos de decisão. A participação pode ser implementada e realizada de diferentes maneiras, em níveis distintos e em dinâmicas próprias no cotidiano escolar, deve também ser uma prática polissêmica, que apresenta diferenças significativas quanto à natureza, ao caráter, às finalidades e ao alcance nos processos de aprendizagem cidadã. Os processos de participação se constituem, eles próprios, em atitudes
} 
Veiga (1998, p.13) aponta o Projeto Político Pedagógico como um documento dinâmico, construído de forma coletiva e democrática, com a participação consciente e efetiva de todos os envolvidos na prática pedagógica, e tem como objetivo organizar e orientar o trabalho escolar e ainda oportuniza aos envolvidos no processo a reflexão sobre a práxis pedagógica. Segundo Libâneo, Oliveira e Toschi (2009, p.345), o "PPP é um documento que propõe uma direção política para o trabalho escolar, fórmula metas, prevê as ações descentralizadas e democratiza a tomada de decisões pedagógicas, jurídicas e organizacionais na escola, buscando maior participação dos agentes escolares".

Todas as ações da escola colocadas no PPP lhe conferem o caráter político, na medida em que ele traduz um processo democrático de construção da cidadania, onde os envolvidos são sujeitos de transformação da prática social existente, com identidade, igualdade de oportunidades a todos, o que reforça a autonomia escolar.

Ter autonomia permite à escola definir seu planejamento e encaminhar seus projetos de acordo com suas demandas. Segundo Gadotti (1994):

Todo projeto supõe rupturas com o presente e promessas para o futuro. Projetar significa tentar quebrar um estado confortável para arriscar-se, atravessar um período de instabilidade e buscar uma nova estabilidade em função da promessa que cada projeto contém de estado melhor do que o presente. Um projeto educativo pode ser tomado como promessa frente a determinadas rupturas. As promessas tornam visíveis os campos de ação possível, comprometendo seus atores e autores. (GADOTTI, 1994, p. 579)

O Projeto Político Pedagógico deve expressar quem é a comunidade escolar, quais são seus desafios com relação à formação, à conquista da autonomia e da gestão democrática. Ele deve organizar, executar e avaliar o trabalho educativo de todos os sujeitos da escola. O projeto político pedagógico é o centro das discussões, as práticas e as propostas especificas e conjunturas das Unidades escolares são necessariamente apontadas no PPP e devem expressar ou assentar-se sobre os seus propósitos, suas diretrizes e princípios. O PPP ao se constituir em documento, é instrumento

\footnotetext{
e disposição de aprendizagem e de mudanças culturais a serem construídas cotidianamente. A participação é um processo complexo, que envolve várias formas e lógicas de participação. Entre os mecanismos de participação que podem ser criados na escola, destacam-se: o conselho escolar, o conselho de classe, a associação de pais e mestres e o grêmio escolar
} 
que direciona, fundamenta e ampara o trabalho da instituição e da comunidade escolar, não se sujeitando ao crivo de aprovação externa, a não ser na hipótese de exame de apreciação de eventual ilegalidade.

Nem sempre esse documento tão importante, pilar das ações escolares, é construido ou reconhecido como baluarte da escola. Em São Paulo, o Conselho Estadual de Educação apresenta o relatório CEE $\mathrm{N}^{\circ}$ : 676/97, trazendo manifestação a respeito de Conceitos de PPP, Regimento Escolar e Plano Escolar. "Tudo começa, desde logo pela elaboração da proposta pedagógica da escola. É o passo primeiro, o ato originário da instituição. Tudo mais deve vir depois. O que se deseja instaurar é o princípio da realidade pedagógica, que se funda na autonomia da escola.

No que tange a organização escolar, temos o Regimento Escolar, um documento com eficácia na regulação das relações de todos os envolvidos no processo educativo, deve ser redigido de maneira clara, é um documento redigido para perdurar, embora possa sofrer alterações e acréscimos destituído de particularidades que são apenas conjunturais. A Indicação CEE n 09/97, relaciona os tópicos que devem constar do Regimento Escolar e que está sujeito à aprovação dos órgãos próprios do sistema. ${ }^{53}$

Temos ainda o Plano Escolar, um instrumento dinâmico que deve ser elaborado anualmente e remetido na época própria às Diretorias Regionais de Ensino. Dele devem constar a operacionalização daquelas medidas incluídas de forma genérica no regimento, e outras que resolvam os aspectos conjunturais da instituição. Assim, devem constar do Plano, mas não necessariamente do Regimento, entre outras consideradas necessárias, as seguintes decisões: datas de matrícula, período para recebimento de transferências, período e detalhes dos procedimentos de classificação e

\footnotetext{
53 Tópicos mínimos a constarem dos regimentos escolares: O regimento escolar, no seu conjunto, deve ser um texto destituído de minúcias e particularidades conjunturais, mas precisa conter um mínimo de preceitos que, refletindo as medidas do estabelecimento para realização de sua proposta pedagógica, regulamentem as relações entre os participantes do processo educativo. São os seguintes os tópicos mínimos: I - Identificação do estabelecimento, com indicação do ato administrativo que autorizou seu funcionamento. II - Fins e objetivos do estabelecimento. III - Organização Administrativa e Técnica. As instituições de ensino devem atentar para o conceito de gestão democrática do ensino, nos termos do Art. $3^{\circ}$, inciso VIII, e Art. 14, ambos da Lei 9.394/96. IV - Organização da vida escolar. Níveis e modalidades de educação e ensino; fins e objetivos dos cursos; mínimos de duração e carga horária; critérios de organização curricular; critérios para composição dos currículos, atendidas a base nacional comum e a parte diversificada; verificação do rendimento escolar, formas de avaliação, recuperação, promoção, retenção, classificação e reclassificação; sistema de controle de frequência; matrícula e transferência; estágios; expedição de históricos escolares, declarações de conclusão de série, certificados de conclusão de cursos e diplomas. V - Direitos e Deveres dos participantes do processo educativo. Princípios que regem as relações entre os participantes do processo educativo; princípios referentes a deveres e direitos dos alunos, professores e pais, as sanções e vias recursais cabíveis. A adequação dos regimentos das escolas às disposições da nova LDB, num primeiro momento, pode-se ater apenas às questões obrigatórias pela própria Lei. A adoção de novas aberturas facultadas pela lei poderá ser postergada para um momento em que a escola tenha mais amadurecida sua nova proposta pedagógica e em que o conjunto de normas e diretrizes, em nível de sistemas articulados, esteja mais consolidado.
} 
reclassificação dos alunos, calendário das aulas e dos demais dias de efetivo trabalho escolar, grades ou matrizes curriculares em uso, sistema de avaliação da aprendizagem, procedimentos de recuperação, forma ou formas de organização dos cursos que serão utilizados no período de atividades docentes diversas, etc.

Aponto que há especificidades da proposta de PPP para as prisões, que coloca em debate e propõe um modelo de PPPprisões em que o território prisional deveria se tornar objeto de políticas públicas educacionais, mas é essencial para este trabalho a apresentação da trajetória, discussões, ideias e encaminhamentos para a concretização da proposta e formato do PPP, como disposto nos parágrafos acima.

Para Boto (1996, p. 15-77) como princípios fundantes, os PPPs devem propor a democratização da escola pública, o acesso e permanência dos alunos, prolongamento do tempo de escola, o direito ao ensino público e gratuito para todos, qualidade do ensino, inovações curriculares, a gestão democrática e a formação (continuada) do professor. Este trabalho está embasado no PPP idealizado como uma política pública que está alicerçado na luta e nos conceitos básicos das propostas de ampla participação dos sujeitos no desenvolvimento de projetos e ações, na inclusão social, na emancipação do sujeito e na democratização da escola. De acordo com Freire (1983, p. 32), "quanto mais alguém, por meio da ação e da reflexão, se aproxima da "razão", do "logos" da realidade, objetiva e desafiadora, tanto mais, introduzindo-se nela, mais alcançará o seu desvelamento. Participando, os sujeitos se afirmam como seres no mundo e com o mundo". Ainda segundo Freire (1983), para tornar a escola um espaço favorável para as melhorias dos seres e de suas atitudes, e para desvelar e enfrentar os conflitos sociais, econômicos sociais e culturais de uma época de dúvidas e incerteza, a participação é um dos princípios para a construção de uma educação transformadora.

Para semear esses caminhos da escola pública, inclusiva, transformadora, Veiga (1998, p. 31) discorre que: "há necessidade de se instalar mecanismos institucionais, visando à participação política de todos os envolvidos com o processo e a construção critica de um Projeto Político Pedagógico como instrumento desenvolvido com foco na formação crítica dos sujeitos, com ampla participação, intervenção, encaminhamentos e decisões dos mesmos e não apenas um comparecimento para validar decisões tomadas isoladamente ou para realizar serviços e tarefas".

Vasconcellos (2009, p. 24) lembra que ainda que "a participação é uma resposta a um dos anseios mais fundamentais do homem: ser levado em conta, tomar parte, ser incluído, ser respeitado" 
e Freire (2009, p. 98) ressaltou que "necessitamos de uma educação para a decisão, para a responsabilidade social e política", apontando para uma educação que possibilite ao sujeitos a discussão corajosa dos problemas pertencentes ao seu tempo e espaço, que abra espaço para o ouvir, pois o diálogo é o diferencial das instituições, dos seres que se propõem mudar práticas, rever posições, recriar espaços e promover desenvolvimento.

É necessário reconhecer que, mesmo sofrendo os resultados de uma história pouco favorável às mudanças que levariam à democratização da escola, como o descaso na formação dos professores, os baixos salários e a deterioração das escolas, concordamos que tivemos avanços, mas sabemos, principalmente na conjuntura atual, que precisamos reiteradamente desenvolver ações propositivas que reafirmem a educação como um trajeto possível para a construção de uma sociedade mais justa, solidária e humana, com participação de todos os envolvidos.

Saliento que o PPP, uma tecnologia social eminentemente brasileira, é uma conquista para enveredarmos no caminho de uma escola dialógica, inclusiva e parte da ideia de que participar é muito mais do que colaborar, mas é envolver-se nas discussões, reflexões e decisões, com sugestões, opiniões, questionamentos e protagonismos para consequentemente termos a construção de uma educação pública com cada vez mais equidade para todos.

Por fim, o PPP ainda permite que as escolas tenham identidade e Paulo Freire (1999, p. 97) tratou da questão das diferenças nos espaços de educação, fazendo a defesa do multiculturalismo. Onde o direito de ser diferente em uma sociedade dita democrática, enquanto uma liberdade conquistada de cada cultura, também deve proporcionar um diálogo crítico entre as diversas culturas, com o objetivo de consolidar e ampliar os processos de emancipação.

\subsection{Projeto político pedagógico das prisões: modelo atual}

A Constituição Federal de 1988, que acompanhada de princípios, leis e tratados internacionais, consagram direitos civis e políticos e as garantias fundamentais aos indivíduos, preconiza os Direitos Humanos e os princípios da dignidade humana e o surgimento de novos sujeitos de direitos. Políticas públicas em saúde, assistência social, educação, atividades desportivas, entre outras são desencadeadas para os que até então se encontravam absolutamente alijados e são concebidas novas legislações, incluindo aquelas que garantem direitos à estas 
pessoas. Também, para que se efetivem a implementação de garantias às pessoas privadas de liberdade, publicam-se diretrizes que orientam execução das garantias desses direitos.

Com o Decreto $\mathrm{n}^{\circ}$ 7.626, de 2011, foi promulgado o Plano Estratégico de Educação no Âmbito do Sistema Prisional, responsabilizando todos os estados brasileiros da tarefa de apresentarem seus Plano Estadual de Educação nas Prisões, e a consequente construção dos Projeto Político Pedagógicos. O Artigo 10 da Resolução CNE/CEB n 2, de 19 de maio de 2010 define que, as atividades laborais e artístico-culturais deverão ser reconhecidas e valorizadas como elementos formativos integrados à oferta de educação, podendo ser contempladas no projeto políticopedagógico como atividades curriculares, desde que devidamente fundamentadas, SILVA, MARQUES (2021) apontam:

[...] que o PPP das prisões possui uma dimensão orgânica e estruturante para as ações de múltiplos atores (projeto); impacta a Execução Penal, os procedimentos disciplinares e a rotina prisional (político); e organiza as condições de ensino, o tempo, o espaço e o currículo (pedagógico). O PPP das prisões possibilita a salutar complementaridade entre a legislação educacional e legislação penal - LDB (BRASIL, 1996) e Lei de Execução Penal (BRASIL, 1984), favorece a articulação entre políticas setoriais - Educação, Trabalho, Saúde, Segurança Pública e Serviço Social, potencializa a sinergia entre duas ciências - Pedagogia e Direito Penitenciário - e mobiliza distintos campos profissionais - professores e agentes penitenciários - em torno de objetivos comuns. (SILVA; MARQUES, 2021, p. 60)

A LDB traz em seus Artigos 14 e 15 a possibilidade de desenvolver atividades diversificadas e como são Estados da Federação os responsáveis pela oferta da Educação nos sistemas prisionais, temos diversos modelos dessa oferta, como podemos observar no quadro abaixo: 
Tabela 2 - Modelos de oferta da educação em prisões no Brasil

\begin{tabular}{|c|c|c|}
\hline MODELO DE OFERTA & ESTADO & YARACTERÍSTICA \\
\hline rência ou Escola & Fsnírit & Trata-se de uma escola regular, sediada na comunidade, na qual \\
\hline Vinculadora & $\begin{array}{l}\text { Minas Gerais, Piauí, Rio } \\
\text { Grande do Norte, São Paulo e }\end{array}$ & $\begin{array}{l}\text { são lotados os professores que lecionam na prisão e } \\
\text { matriculados presos e presas que queiram estudar. Esta escola }\end{array}$ \\
\hline Escola Certificadora & Sergipe. & $\begin{array}{l}\text { faz todos os registros escolares e emite a documentação escolar } \\
\text { necessária. }\end{array}$ \\
\hline Escola Penitenciaria & $\begin{array}{l}\text { Amapá, Amazonas, } \\
\text { Pernambuco, Rio de Janeiro e } \\
\text { Tocantins. }\end{array}$ & $\begin{array}{l}\text { É o modelo mais antigo existente no Brasil, em que a escola está } \\
\text { situada dentro da Unidade Prisional, com toda sua estrutura e } \\
\text { equipe. Por determinação de lei elas tiveram que adotar nomes } \\
\text { convencionais para que a documentação escolar, certificados e } \\
\text { diplomas não identifiquem a Penitenciaria como local de } \\
\text { estudos. }\end{array}$ \\
\hline Anexos e Extensões & $\begin{array}{l}\text { Bahia, Goiás, Maranhão e } \\
\text { Roraima. }\end{array}$ & $\begin{array}{l}\text { Trata-se de uma escola regular que mantêm anexos e/ou } \\
\text { extensões em uma ou mais unidades prisionais. Professores, } \\
\text { presos e presas que estudam têm esta escola com referência para } \\
\text { efeito de trabalho, matrícula e documentação escolar. }\end{array}$ \\
\hline CEEJA & $\begin{array}{l}\text { Ceará, Pará, Paraíba, Paraná, } \\
\text { Rio Grande do Sul, Rondônia } \\
\text { e Santa Catarina. }\end{array}$ & $\begin{array}{l}\text { Professores são vinculados a um Centro de Educação de Jovens } \\
\text { e Adultos, que também recebe s matrícula e documentação } \\
\text { escolar. }\end{array}$ \\
\hline Escola Polo & $\begin{array}{l}\text { Distrito Federal, Mato Grosso } \\
\text { e Mato Grosso do Sul. }\end{array}$ & $\begin{array}{l}\text { Uma única escola (Centro Educacional } 01-\mathrm{DF} \text { ), (Nova Chance } \\
\text { - MT) e (Regina Bettini - MS) centraliza em todo estado a } \\
\text { vinculação institucional de professores e a matrícula de todos os } \\
\text { presos e presas que estejam estudando. }\end{array}$ \\
\hline
\end{tabular}

Fonte: SILVA, MARQUES (2021, p. 52)

O Brasil tem dimensões continentais e sua imensa área é dividida em 26 Estados e 1 Distrito Federal e ainda administra um dos maiores sistemas penitenciários do mundo. Foram vários os motivos que levaram o Brasil ao modelo de divisão do seu território, mas destacamos como fundamentais os fatores históricos e político-administrativos, que se iniciaram ainda no período colonial, o que faz com tenhamos além da possibilidade de maior controle administrativo do território, subdividindo as responsabilidades de implementar políticas e fiscalização em partes menores, conjunturas específicas tanto na Educação quanto no seu sistema penitenciário. Entretanto, há documentos federais de referência que subsidiam a implementação das políticas em seus respectivos aparelhos prisionais. Silva, Marques (2021) os elenca:

1. Plano Estadual de Educação. Nos Estados em que ele existe é pertinente verificar se ele faz alguma referência à Educação em prisões.

2. Plano Diretor do Sistema Penitenciário. Dentre suas 22 metas, merece atenção a Meta 15 (Educação e profissionalização), na qual se faz o detalhamento quanto ao nível de escolaridade de toda a população prisional no Brasil.

3. Plano Operativo Estadual de Saúde no Sistema Penitenciário. Desdobramento do Plano Nacional de Saúde no Sistema Penitenciário, que coloca a atenção à saúde do preso como atribuição do Sistema Único de Saúde (SUS). 
4. Deliberações do Conselho Estadual de Educação sobre a oferta da Educação em Prisões ou, analogamente, sobre Educação de Jovens e Adultos e Educação Técnica e Profissional. Observada a diretriz que determina ser a Educação em prisões obrigação do Estado por meio da articulação entre as secretarias que cuidam das prisões e da Educação, uma primeira definição a se fazer é quanto à forma de organização do sistema de ensino para atender as unidades prisionais. (SILVA, MARQUES, 2021, P. 63)

Para além do que se coloca comum ou característico ao modelo adotado, no quadro abaixo é possível observar que na prática, poucos estados da União apresentaram ou desenvolvem um PPP específico para as prisões:

Quadro 3 - Estados com PPP específico para prisões

\begin{tabular}{|c|c|c|c|c|}
\hline $\mathbf{U F}$ & Elaborado & EJA & Outros & PPP específico \\
\hline $\mathrm{AC}$ & SIM & SIM & EF e EM & Práticas Pedagógicas e Atendimento à Diversidade \\
\hline $\mathrm{AL}$ & SIM & Sim & EM & Não \\
\hline $\mathrm{AM}$ & SIM & SIM & $\mathrm{EF}, \mathrm{EM}, \mathrm{EAD}$ & Não \\
\hline $\mathrm{AP}$ & SIM & Não & EF e EM & Não \\
\hline $\mathrm{BA}$ & SIM & SIM & EF e EM & Não \\
\hline $\mathrm{CE}$ & NÃO & NI & NI & NI \\
\hline DF & NÃO & NI & NI & NI \\
\hline ES & NÃO & NI & NI & NI \\
\hline GO & SIM & SIM & EF e EM & EJA Prisional \\
\hline MA & SIM & SIM & EF e EM & Não \\
\hline MG & SIM & SIM & EF, EM e ES & PPP Prisional \\
\hline MS & SIM & SIM & EF e EM & PPP Prisão que educa \\
\hline $\mathrm{PA}$ & SIM & SIM & não & Não \\
\hline $\mathrm{PB}$ & SIM & SIM & EF e EM & Não \\
\hline $\mathrm{PE}$ & NÃO & NI & NI & NI \\
\hline PI & SIM & SIM & EF e EM & Não \\
\hline PR & SIM & SIM & CEEBJA & Não \\
\hline $\mathrm{RJ}$ & SIM & SIM & EF e EM & PPPs das escolas prisionais \\
\hline $\mathrm{RN}$ & SIM & SIM & CEEJA & Não \\
\hline $\mathrm{RO}$ & SIM & SIM & CEEJA & Não \\
\hline $\mathrm{RR}$ & SIM & SIM & EAD & Não \\
\hline RS & SIM & SIM & $\begin{array}{c}\text { NEEJA, EF e } \\
\text { EM }\end{array}$ & Regimentos de escola e Formação docente específicos \\
\hline $\mathrm{SC}$ & SIM & SIM & EF e EM & Prisão que educa \\
\hline SE & SIM & SIM & EF e EM & Não \\
\hline SP & SIM & SIM & $\operatorname{sim}$ & Não \\
\hline $\mathrm{TO}$ & NÃO & NI & $\mathrm{NI}$ & NI \\
\hline
\end{tabular}

Fonte: https://legado.justica.gov.br/modelo-de-gestao_documento-final.pdf/view 
Ressalto o apontado no antigo Parecer CFE nº 699/72, que atribui à EJA três funções básicas: reparadora, equalizadora e permanente ou qualificadora e como já dito aqui, a Educação em Prisões requer uma nova arquitetura pedagógica, com novo modelo de organização, de atendimento e uma nova concertação entre as várias ciências que atuam no contexto prisional, com compatibilidade entre os objetivos e metas para garantias de direitos Educação. Para SILVA, MOREIRA,

Enquanto prevalecer a concepção de prisão como espaço de confinamento, de castigo, de humilhação e de estigmatização social a Educação não terá lugar na terapia penal, limitandose a ser, como efetivamente tem sido, apenas mais um recurso a serviço da administração penitenciária para ocupar o tempo ocioso de alguns poucos presos e evitar que se envolvam em confusões. (SILVA, MOREIRA, 2006, p. 12).

O período de redemocratização do Brasil e as lutas por direitos, entre eles à educação, gestaram entre outras coisas, uma educação que aprendeu a trabalhar com a diversidade, produzindo resultados legais, a partir da publicação de diretrizes que contemplam quase todo o espectro das necessidades educacionais, tais como quilombolas, ribeirinhos, indígenas, nas prisões. Apresento abaixo um histórico de Diretrizes ${ }^{54}$ para estas modalidades educacionais:

Quadro 4- Histórico de diretrizes para modalidades educacionais

Parecer CNE/CP n. ${ }^{\circ}$ 3, de 10 de março de 2004 - Institui Diretrizes Curriculares Nacionais para a Educação das Relações Étnico-Raciais e para o Ensino de História e Cultura Afro-Brasileira e Africana; Resolução CNE/CP n. ${ }^{\circ}$ 1, de 17 de junho de 2004 Institui Diretrizes Curriculares Nacionais para a Educação das Relações Étnico-Raciais e para o Ensino de História e Cultura Afro-Brasileira e Africana.; Parecer CNE/CEB $n^{\circ}$ 2/2007, aprovado em 31 de janeiro de 2007 - Parecer quanto à abrangência das Diretrizes Curriculares Nacionais para a Educação das Relações Étnico-Raciais e para o Ensino de História e Cultura Afro-Brasileira e Africana; Parecer CNE/CEB $n^{\circ}$ 6/2011, aprovado em $1^{\circ}$ de junho de 2011 - Reexame do Parecer CNE/CEB n ${ }^{\circ}$ 15/2010,

Étnico-Raciais com orientações para que material utilizado na Educação Básica se coadune com as políticas públicas para uma educação antirracista; Parecer CNE/CEB no 14/2015, aprovado em 11 de novembro de 2015 - Diretrizes Operacionais para a implementação da história e das culturas dos povos indígena na Educação Básica, em decorrência da Lei $\mathrm{n}^{\circ} 11.645 / 2008$.

Parecer CNE/CEB no 36/2001, aprovado em 4 de dezembro de 2001 - Diretrizes

\section{Educação do Campo} Operacionais para a Educação Básica nas Escolas do Campo; Resolução CNE/CEB no 1, de 3 de abril de 2002 - Institui Diretrizes Operacionais para a Educação Básica nas Escolas do Campo; Resolução CNE/CEB no 2, de 28 de abril de 2008 - Estabelece diretrizes complementares, normas e princípios para o desenvolvimento de políticas

\footnotetext{
${ }^{54}$ Destaco que há ainda inúmeros pareceres publicados para cada um dos modelos.
} 
públicas de atendimento da Educação Básica do Campo; Parecer CNE/CP nº 22/2020, aprovado em 8 de dezembro de 2020 - Diretrizes Curriculares da Pedagogia da Alternância na Educação Básica e na Educação Superior.

Parecer CNE/CEB nº 8/2015, aprovado em 7 de outubro de 2015 - Diretrizes Nacionais para o atendimento escolar de adolescentes e jovens em cumprimento de medidas socioeducativas: Resolução CNE/CEB n ${ }^{\circ}$ 3, de 13 de maio de 2016 - Define Diretrizes Nacionais para o atendimento escolar de adolescentes e jovens em cumprimento de medidas socioeducativas.

Parecer CNE/CEB no 4/2010, aprovado em 9 de março de 2010 - Diretrizes Nacionais para a oferta de educação para jovens e adultos em situação de privação de liberdade nos estabelecimentos penais; Resolução CNE/CEB $\mathrm{n}^{\circ}$ 2, de 19 de maio de 2010 - Dispõe sobre as Diretrizes Nacionais para a oferta de educação para jovens e

$\begin{array}{cl}\begin{array}{c}\text { Educação nas } \\ \text { Prisões }\end{array} & \text { adultos em situação de privação de liberdade nos estabelecimentos penais; Parecer } \\ \text { CNE/CEB n } & \text { 5 5/2015, aprovado em } 10 \text { de junho de } 2015 \text { - Remição de pena pelo estudo }\end{array}$ de pessoas em privação de liberdade no sistema prisional brasileiro; Resolução CNE/CEB $n^{\circ}$ 4, de 30 de maio de 2016 - Dispõe sobre as Diretrizes Operacionais Nacionais para a remição de pena pelo estudo de pessoas em privação de liberdade nos estabelecimentos penais do sistema prisional brasileiro.

$\begin{array}{cl}\text { Educação } & \text { Parecer CNE/CEB no 14/2011, aprovado em } 7 \text { de dezembro de } 2011 \text { - Diretrizes para } \\ \text { Escolar para } & \text { o atendimento de educação escolar de crianças, adolescentes e jovens em situação de } \\ \text { Populações em } & \text { itinerância; Resolução CNE/CEB no 3, de } 16 \text { de maio de } 2012 \text { - Define diretrizes para } \\ \text { Situação de } & \text { o aten imento de educação escolar para populações em situação de itinerância. }\end{array}$ Itinerância

Parecer CNE/CEB n 1/2020, aprovado em 21 de maio de 2020 - Regulamentação da inclusão matrícula de crianças e adolescentes migrantes, refugiados, apátridas e solicitantes de refúgio no sistema público de ensino brasileiro; Resolução CNE/CEB $\mathrm{n}^{\circ} 1$, de 13 de novembro de 2020 - Dispõe sobre o direito de matrícula de crianças e adolescentes migrantes, refugiados, apátridas e solicitantes de refúgio no sistema público de ensino brasileiro.

Parecer CNE/CEB $n^{\circ}$ 16/2012, aprovado em 5 de junho de 2012 - Diretrizes Curriculares Nacionais para a Educação Escolar Quilombola; Resolução CNE/CEB n ${ }^{\circ}$

Educação 8, de 20 de novembro de 2012 - Define Diretrizes Curriculares Nacionais para a Quilombola Educação Escolar Quilombola na Educação Básica; Parecer CNE/CEB nº 8/2020, aprovado em 10 de dezembro de 2020 - Diretrizes Nacionais Operacionais para a garantia da Qualidade das Escolas Quilombolas.

Parecer CNE/CEB n ${ }^{\circ}$ 14/1999, aprovado em 14 de setembro de 1999 - Dispõe sobre as Diretrizes Nacionais para o funcionamento das escolas indígenas; Resolução CNE/CEB n. ${ }^{\circ}$ 3, de 10 de novembro de 1999 - Fixa Diretrizes Nacionais para o funcionamento das escolas indígenas e dá outras providências; Parecer $\mathrm{CNE} / \mathrm{CP}$ n. ${ }^{\circ} 10$, de 11 de março de 2002 - Responde consulta sobre formação do professor indígena em nível universitário; Parecer CNE/CEB n ${ }^{\circ}$ 13/2012, aprovado em 10 de maio de 2012 Diretrizes Curriculares Nacionais para a Educação Escolar Indígena. Resolução $\mathrm{CNE} / \mathrm{CEB} \mathrm{n}^{\circ}$ 5, de 22 de junho de 2012 - Define Diretrizes Curriculares Nacionais para

Educação Escolar Indígena aprovado em 2 de abril de 2014 - Diretrizes Curriculares Nacionais para a Formação de Professores Indígenas; Resolução CNE/CP nº 1, de 7 de janeiro de 2015 - Institui Diretrizes Curriculares Nacionais para a Formação de Professores Indígenas em cursos de Educação Superior e de Ensino Médio e dá outras providências; Parecer CNE/CEB $n^{\circ}$ 9/2015, aprovado em 7 de outubro de 2015 - Orientações para a promoção do acesso de povos indígenas de recente contato a processos educacionais.; Parecer $\mathrm{CNE} / \mathrm{CEB} \mathrm{n}^{\circ}$ 14/2015, aprovado em 11 de novembro de 2015 - Diretrizes Operacionais para a implementação da história e das culturas dos povos indígena na Educação Básica, em 
decorrência da Lei ${ }^{\circ}$ 11.645/2008.

Parecer CNE/CEB n ${ }^{\circ}$ 17/2001, aprovado em 3 de julho de 2001 - Diretrizes Nacionais para a Educação Especial na Educação Básica; Resolução CNE/CEB nº 2/2001, de 11 de setembro de 2001 - Institui Diretrizes Nacionais para a Educação Especial na Educação Básica; Parecer CNE/CEB no 35/2003, aprovado em 5 de novembro de 2003 - Aprova Projeto de Resolução que estabelece Diretrizes Nacionais para a organização e a realização de Estágio de alunos da Educação Profissional e do Ensino

Educação Especial

Educação de Jovens e Adultos Médio; Resolução CNE/CEB n ${ }^{\circ}$ 1, de 21 de janeiro de 2004 - Estabelece Diretrizes Nacionais para a organização e a realização de Estágio de alunos da Educação Profissional e do Ensino Médio, inclusive nas modalidades de Educação Especial e de Educação de Jovens e Adultos; Resolução CNE/CEB no 4, de 2 de outubro de 2009 Institui Diretrizes Operacionais para o Atendimento Educacional Especializado na Educação Básica, modalidade Educação Especial.

Parecer CNE/CEB no 11/2000, aprovado em 10 de maio de 2000 - Dispõe sobre as Diretrizes Curriculares Nacionais para a Educação de Jovens e Adultos; Resolução $\mathrm{CNE} / \mathrm{CEB} \mathrm{n}^{\circ}$ 1, de 5 de julho de 2000 - Estabelece as Diretrizes Curriculares Nacionais para a Educação de Jovens e Adultos; Parecer CNE/CEB n 36/2004, aprovado em 07 de dezembro de 2004 - Aprecia a Indicação CNE/CEB 3/2004, que propõe a reformulação da Resolução CNE/CEB 1/2000, que define Diretrizes Curriculares Nacionais para a Educação de Jovens e Adultos; Parecer CNE/CEB n ${ }^{\circ}$ 20/2005, aprovado em 15 de setembro de 2005 - Inclusão da Educação de Jovens e Adultos, prevista no Decreto $n^{\circ} 5.478 / 2005$, como alternativa para a oferta da Educação Profissional Técnica de nível médio de forma integrada com o Ensino Médio.; Resolução CNE/CEB n ${ }^{\circ}$, de 27 de outubro de 2005 - Inclui novo dispositivo à Resolução CNE/CEB 1/2005, que atualiza as Diretrizes Curriculares Nacionais definidas pelo Conselho Nacional de Educação para o Ensino Médio e para a Educação Profissional Técnica de nível médio às disposições do Decreto ${ }^{\circ}$ 5.154/2004; Parecer CNE/CEB no 29/2006, aprovado em 5 de abril de 2006 - Reexame do Parecer CNE/CEB no 36/2004, que aprecia a Indicação CNE/CEB n $3 / 2004$, propondo a reformulação da Resolução CNE/CEB n ${ }^{\circ} 1 / 2000$, que definiu Diretrizes Curriculares Nacionais para a Educação de Jovens e Adultos; Parecer CNE/CEB no 23/2008, aprovado em 8 de outubro de 2008 - Institui Diretrizes Operacionais para a Educação de Jovens e Adultos - EJA nos aspectos relativos à duração dos cursos e idade mínima para ingresso nos cursos de EJA; idade mínima e certificação nos exames de EJA; e Educação de Jovens e Adultos desenvolvida por meio da Educação a Distância; Parecer CNE/CEB n ${ }^{\circ}$ 6/2010, aprovado em 7 de abril de 2010 - Reexame do Parecer CNE/CEB $n^{\circ}$ 23/2008, que institui Diretrizes Operacionais para a Educação de Jovens e Adultos - EJA, nos aspectos relativos à duração dos cursos e idade mínima para ingresso nos cursos de EJA; idade mínima e certificação nos exames de EJA; e Educação de Jovens e Adultos desenvolvida por meio da Educação a Distância; Resolução CNE/CEB no 3, de 15 de junho de 2010 - Institui Diretrizes Operacionais para a Educação de Jovens e Adultos nos aspectos relativos à duração dos cursos e idade mínima para ingresso nos cursos de EJA; idade mínima e certificação nos exames de EJA; e Educação de Jovens e Adultos desenvolvida por meio da Educação a Distância; Parecer CNE/CEB n ${ }^{\circ}$ 6/2020, aprovado em 10 de dezembro de 2020-Alinhamento das Diretrizes Operacionais para a Educação de Jovens e Adultos (EJA) apresentadas na Base Nacional Comum Curricular (BNCC), e outras legislações relativas à modalidade. Parecer CNE/CEB n ${ }^{\circ}$ 1/2021, aprovado em 18 de março de 2021 - Reexame do Parecer CNE/CEB n ${ }^{\circ}$ 6, de 10 de dezembro de 2020, que tratou do alinhamento das Diretrizes Operacionais para a Educação de Jovens e Adultos (EJA) apresentadas na Base Nacional Comum Curricular (BNCC), e outras legislações relativas à modalidade. 

Educação para Programa Nacional de Educação em Direitos Humanos (PNDH-3). Brasília: Secretaria os Direitos Especial de Direitos Humanos, 2010. Diretrizes Nacionais para a Educação em Direitos Humanos Humanos. Resolução CNE/CP, 2012b

Fonte: elaborada pela autora (2021)

Mas, como observamos, apesar de termos publicadas as diretrizes que orientam o atendimento as estas demandas, não temos parametrizados modelos de atendimento. No que tange a educação nas prisões, na ausência de delineamento de modelos para desenvolvimento da educação, cabe à comunidade do território prisional, e nesse momento, também a escola pública que a atende, organizar as propostas para desenvolvimento da educação dentro das Unidades. Na maioria dos Estados são transposições do trabalho desenvolvido no território escolar, sem considerar as especificidades que estão colocadas para a educação no cárcere.

Observa-se avanços na de oferta de educação para toda população, buscando-se assim, garantir direito de acesso historicamente previstos na legislação brasileira, a partir das publicações de Diretrizes, Resoluções e Pareceres para regulamentação, ampliação e oferta de educação básica a públicos específicos. Em um país onde há tantas especificidades e diversidades a serem atendidas, não é mais novidade, quando vemos tantos pareceres de atendimento as diversas minorias e níveis de educação, mas é desafiador, quando vemos que são mínimas as resoluções e pareceres que se preocupam em propor um modelo educacional específico para atendimento à população encarcerada.

Há inúmeras considerações a serem feitas quando pensamos em educação nas prisões: como encaminhar avaliações diagnósticas, para conhecer o aluno e definir, em comum acordo as políticas educacionais a serem desenvolvidas, como desenvolver programas e projetos significativos, como organizar o processo ensino aprendizagem, como desenvolver ações que objetivem emancipação e reintegração dos sujeitos do cárcere?

\subsection{Projeto político pedagógico da Educação em prisões (PPPprisões): proposições do GEPÊPRIVAÇÃO}

Início esse item abordando que as proposições desenvolvidas nessa pesquisa qualitativa estão embasadas em arcabouços teóricos bibliográficos e legais, na pesquisa dos membros do GEPEPRIVAÇÃO e na pesquisa participativa, que desenvolvi a partir da minha práxis como Supervisora de Ensino. 
Em campo, foi possível a esta pesquisadora e aos membros do GEPEPRIVAÇÃO, problematizarem, a partir de seus diferentes temas de pesquisa, concepções sobre o atual modelo do Programa de Educação em prisões de São Paulo.

Entre os trabalhos de pesquisa acadêmicas de doutorado, pesquisas de iniciação cientifica e relatórios, desenvolvidos no cerne do GEPEPRIVAÇÃO e que dão embasamento as proposições desenvolvidas nesta dissertação temos:

1. A tese de doutorado de CAROLINA BESSA FERREIRA DE OLIVEIRA, intitulada "A educação nas prisões brasileiras: a responsabilidade da universidade pública" (2017) que discute a concretização do direito à educação nas prisões por meio de políticas públicas pautadas na territorialização e fomenta o debate de possíveis bases territoriais para a consecução de uma política pública de educação em prisões, como formas de percepção e organização de ações e relações em um dado espaço com a articulação dos diferentes atores e instituições, como sociedade civil e universidades públicas. A autora desenvolve discussão sobre o papel do Estado na garantia do direito à educaçãoe, as implicações do exercício desse direito pelas pessoas presas e pauta o território como balizador da implementação de políticas públicas.

\begin{abstract}
A discussão sobre as políticas públicas passa, necessariamente, pela compreensão do papel do Estado como o seu executor principal e pela responsabilidade de suas instituições neste processo. Trata-se de uma discussão relevante, sobretudo, no contexto das sociedades capitalistas modernas, em que, diante das desigualdades existentes, faz-se necessário lutar pela garantia de direitos básicos, de grande parte da população, por meio da implementação de políticas públicas sociais e da construção da cidadania e acesso ao conjunto dos serviços e bens produzidos na sociedade. (...) O reconhecimento e afirmação do direito de todos à educação, que deve ser garantido pelo Estado por meio da educação pública, está presente nos mais diversos discursos, pautas, movimentos sociais e no campo programático como resultado de processos históricos, políticos e sociais, em normas e documentos nacionais e internacionais. No tempo presente, a discussão sobre o direito humano e universal à educação centra- se em como desenvolver uma prática educativa que tenha adaptabilidade a diferentes públicose contextos, com maior cobertura de atendimento, oferta e que seja de qualidade. (...) O exercício desse direito pelas pessoas privadas de liberdade apresenta especificidades, seja porque o espaço da prisão, punitivo por excelência, não tem conseguido garantir o conjunto de direitos mantidos no cumprimento da pena, seja pelo papel desempenhado pela educação nesse contexto. (OLIVEIRA, 2017, p. 32-56).
\end{abstract}

Oliveira (2017) aponta que é fundamental asseverar o papel do Estado no desenvolvimento e implementação de políticas públicas de educação, incluindo educação em prisões. Esclarece que é profícua a articulação entre Estado, sociedade civil e universidade pública, que, somando esforços, competências e recursos, podem articular níveis de ensino, profissionais e promover ações territorializadas nos espaços prisionais. 
A tese de doutorado de Oliveira (2017) apresenta possibilidades territoriais de atuaçao das universidades públicas no Estado de SãoPaulo, a partir de cruzamento de informações do território e formas cartográficas de análise, cruzando prisões e universidade.

\begin{abstract}
A produção de mapeamentos, na buscade possibilidades de elaboração de políticas públicas e atendimento às demandas de um público em um território, vem ocorrendo em diversos campos de atuação no Brasil, notadamente os que implicam no reconhecimento de novos territórios - como terras indígenase quilombolas, e no ordenamento territorial - como os Planos Diretores.(OLIVEIRA, 2017, p. 186)
\end{abstract}

Oliveira (2017) aponta que a construçao de bases territoriais pode oportunizar que diferentes atores e objetivos educacionais se desenvolvam em uma localidade e que a construção de uma política pública de educação nas prisões impõe uma necessária articulação de diferentes órgãos, instituições e atores, áreas temáticas e âmbitos de atuação, políticas administração penitenciária, envolvendo, necessariamente, a ampliação do acesso e permanência às políticas educacionais.

2. Os projetos desenvolvidos por JOÃO PEDRO INNECCO, resultaram em dois relatórios de iniciação cientifica: “Arte e Educação: significados e sentidos das práticas artísticas e culturais na prisão" (2019) e "Entre Versos e Vigas: a poesia como ferramenta de educação social para pessoas em privação de liberdade" (2017). O trabalho com projetos em penitenciárias e centros de detenção provisória trouxe contribuições indicativas a esta dissertação acerca de trabalhos com projetos:

O Sarau Asas Abertas, que é uma terceira via de atuação socioeducativa, não operada pelo Estado e seus interesses, mas pelos interesses e metodologias próprios que vão se construindo numa prática experimental que contempla, através da arte, aspectos sociais, materiais, educacionais, jurídicos, religiosos e, finalmente, de saúde mental. É um projeto do coletivo Poetas do Tietê e que inicia sua história em 2014 na Penitenciária Feminina do Butantã, de regime semiaberto, em São Paulo/SP, onde Jaime era facilitador de atividades. Jaime é o idealizador da ação que entende a poesia como instrumento de educação e transformação. João Innecco reforça os projetos desenvolvem a teoria do reconhecimento, os participantes dos projetos arte educativos, desenvolvem possiblidades de se reconhecerem em outros lugares que não o do encarcerado. Desenvolvendo a construção da autoestima, autoconfiança e autorrespeito a partir da estima, confiança e respeito pelo próximo.

[...]O preso da vez ao aprendiz, ao poeta, ao escritor. Se reconhecem no lugar de produção de cultura, de produção do discurso, no lugar de autoria.

João Innecco avalia que os dois projetos desenvolvidos são fomentos, incentivos a leitura e de exercer o direito a literatura, contribuindo para educação do olhar, difusão da leitura, do letramento, e político 
[...] há ainda a possibilidade de desenvolver a ciência do texto poético, pois o texto poético/literário é carregado ciência, e se é carregado de ciência, dá acesso, é aliado a todas as áreas do currículo.

João Innecco, membro do GEPEPRIVAÇÃO ainda corrobora com proposições dessa dissertação quando apresenta:

[...] que não havia metodologias desenhadas para as ações desenvolvidas nos espaços de privação de liberdade em que atuou, buscou então a partir de discussões no GEPEPRIVAÇÃO pesquisar várias ações que eram desenvolvidas na penitenciaria feminina da capital, observando várias ações e concluiu que

[...] os projetos em sua grande maioria eram ligados a reintegração social, gerenciados pela psicóloga. Esses projetos se desenvolviam isoladamente, sem metodologia, sem integração, sem objetivos, com os profissionais trabalhando separadamente e sem avaliação.

[...] Há várias lacunas no desenvolvimento desses projetos, vários desencontros, falta de comunicação, descompromisso com a educação e com a reintegração.

[...] As ações se tornam espontaneístas, com vistas a interesses difusos e individuais, com todas as ciências, com exceção da ciência jurídica, se submetendo a rotina e aos encaminhamentos de segurança.

3. Margarete Hiromi Kishi Diniz, membro do GEPEPRIVAÇÃO, que desenvolve projetos nos Centros de Progressão e Detenção provisória avalia:

\begin{abstract}
Observei uma visível melhora nas relações sociais entre elas, e no final do ano, senti um profundo sentimento de afeto entre nós. Elas afetaram em mim o que tenho de melhor, e acredito que a Música as afetou no que elas têm de melhor. Em muitos momentos, cantar não é fácil. A voz parece embargar, e o som emudece sufocando nossas dores. Não encontramos motivos para cantar ou dançar em um ambiente tão hostil. Mas ao romper essas barreiras e ao desafiar todas as grades que nos prendem, conseguimos entoar um som, dois sons... uma melodia inteira! O corpo vai entrando em sintonia rítmica e melódica e vamos sendo contagiados pela música. Naquele breve tempo de 1 hora e meia, com certeza, a ocitocina aumenta e o cortisol diminui, melhorando assim, seu humor, seu ânimo e sua disposição física para enfrentar mais um dia de reclusão e longe de seus familiares e amigos.

[...] Trabalhar o corpo dessas mulheres em situação de privação de liberdade é de suma importância para que elas possam despertar e expandir seus desejos e vontades através do canto e da expressão corporal e possam resgatar sua identidade e sensibilidade afetiva. No começo houve certa resistência, ou inibição? Ou talvez, certo desconforto em lidar com a liberdade de poder se expressar, uma alternativa impensada na sua atual situação de vida. Aos poucos, cuidamos para proporcionar um ambiente seguro para que se sentissem confortáveis em se expressar seja falando, cantando e/ou dançando.
\end{abstract}

4. Os relatórios de iniciação científica intitulados: "O papel e a função das Escolas Vinculadoras na Educação em Prisões no Estado de São Paulo” (2019) de Letícia Camile de Souza Ananias e "A Escola Vinculadora para atendimento à Educação em prisões no Estado de São Paulo" (2019) de Livia Tupinambá Mattiello, pesquisadoras do GEPEPRIVAÇÃO, a partir da observação 
participante em duas Unidades Prisionais, que contam com classes geridas por escolas vinculadoras, contribuíram com a análise das escolas vinculadoras:

[...] A Escola Vinculadora é, portanto, uma escola pública estadual que além de atender aos seus alunos regulares, atende aos presos que manifestem interesse em estudar. Sendo assim, a denominada Escola Vinculadora tem dois corpos docentes, dois corpos discentes, porém, apenas uma equipe gestora e um único Projeto Político Pedagógico (PPP). Vale ressaltar que na maioria das unidades escolares, o PPP só faz menção ao atendimento do público regular que não estejam em condição de privação de liberdade.

[...] As prisões não possuem secretária escolar, direção, administração ou coordenação pedagógica próprias, dessa forma, todo esse corpo pedagógico e administrativo se situa nas unidades vinculadoras.

Consequentemente, há uma sobrecarga de trabalho para uma equipe que precisa gerenciar praticamente duas escolas com demandas pedagógicas e administrativas diferentes. Destacase ainda que assim como os alunos da rede regular, toda a vida escolar dos reeducandos deve estar na Secretaria Escolar Digital (SED), por onde são feitas as matrículas, baixastransferências e registros da vida escolar

[...] No universo prisional todos os envolvidos na execução penal trabalham dentro de uma mesma lógica, a da Segurança e Disciplina. Esta lógica é determinante do fluxo de trabalho de todas as demais áreas e determinam o que, como e quando suas atividades podem ser realizadas. Essa questão está atravessada por diversos impasses, podemos ilustrar com os seguintes exemplos: por parte da maioria dos profissionais da SAP a Educação ainda é vista como um privilégio e não um direito, enquanto para o educadores e gestores da Educação há um entendimento não só do direito, mas da obrigação do Estado nessa oferta e atendimento; professores da rede estadual são recebidos nas portas das unidades prisionais como um visitante qualquer, submetidos aos mesmos procedimentos de revistas e de restrições para ingresso de materiais de trabalho.

[...] é possível notar que este modelo de organização de educação prisional pode realmente não ser o mais eficaz, apesar de ser notável que diversas partes envolvidas se esforçam para seu bom funcionamento. Na secretaria escolar havia cerca de três funcionários, mas nenhum tinha a tarefa de cuidar das escolas dos Centros prisionais, sendo está feita por quem soubesse do que se tratava, ou então por diversas vezes pela pesquisadora que também estava na escola cumprindo seu papel de bolsista PUB dentro do grupo de estudos.

[...] a comunicação entre a escola vinculadora e as unidades é feita quase que exclusivamente por e-mail, esta troca acaba por ser muito falha e muitas vezes acarreta numa perda para o próprio aluno. Uma explicação plausível para o porquê de a comunicação não funcionar bem entre as instalações e consequentemente a gestão de vida escolar dos alunos presos, é a questão de que tudo é feito de forma separada entre as escolas. Mesmo os professores atuantes nas Unidades serem locados na escola vinculadora, os ATPCs ${ }^{55}$ deles e dos professores atuantes na escola regular são feitos em dias distintos, não contando com a presença do outro grupo e nem da equipe gestora da escola, sendo apenas os professores e a Supervisora de Ensino. [...] Não há troca entre as escolas e muitas vezes nenhum conhecimento por parte da escola vinculadora sobre o que ocorre nas classes prisionais. Também um reflexo disso é o próprio PPP, que não pode ser acessado, mas que de acordo com a gestão da época não contava com menções às escolas classes da Unidade Prisionais.

[...] É importante ressaltar que apesar da falta de comunicação e de muitas vezes do trabalho esvaziado de sentido, o sistema consegue funcionar e garantir na maioria das vezes que os alunos sejam inseridos no meio escolar.

55 Atividades pedagógicas de trabalho coletivo 
6. O trabalho de Anabel Grimm e Araújo, também membro do GEPEPRIVAÇÀO, apresentou o relatório de iniciação cientifica “A atuação do educador social na rede pública de ensino na cidade de São Paulo (2020) nos aponta problematizações em relação ao educador Social e sua profissionalização ${ }^{56}$ :

[...] percebe-se que a motivação em comum (do educador social) é a insatisfação do mundo como ele está e a busca constante pela transformação social que garanta a humanidade de todos os seres humanos. É a capacidade de solidarizar-se com o outro, a partir da relação entre sujeitos. No prefácio do livro, Pedagogia Social Vol. XI - Uma abordagem pedagógica para os problemas e conflitos sociais, em que estão publicadas pesquisas apresentadas nos Congressos Internacionais de Pedagogia Social (CIPS), a seguinte afirmação é feita sobre a figura do educador social: Essa recusa de aceitar as injustiças da realidade de um país assolado pela desigualdade social aparece na fala de todos os entrevistados como a principal motivação para se seguir na profissão, de formas diversas, seja impulsionada pela esperança ou pela luta. [...] Assim, é pertinente pensar na identidade profissional do educador social pautando-se nesse desejo em comum pela mudança e na incapacidade de se conformar com as injustiças do mundo, sensibilidades que decorrem principalmente das histórias de vidas dos sujeitos, incluindo as relações que eles travam com aqueles ao seu redor e com a valorização simbólica da educação como ferramenta de intervenção na sociedade.

Considero importante, apresentar o tópico da pesquisa da Anabel, em que é possível observar como são amplas as dificuldades a serem enfrentadas pelo profissional que considero como fundamental para o desenvolvimento do PPP das prisões:

[...]Com auxílio da bibliografia já escrita por pesquisadores brasileiros e da legislação em disputa, foram levantados alguns pontos considerados essenciais para a construção de perspectivas de futuro para esse grupo de educadores. Nota-se uma grande demanda por

56 O educador social desempenha um papel importante junto dos sujeitos com os quais interage, pois dele depende uma integração social positiva nos contextos em que vivem. O seu trabalho, orientado por critérios de competência profissional baseada em metodologias e técnicas orientadas para uma prática social de intervenção, corresponde, no dizer da Carvalho e Baptista (2004), a um espaço profissional desenhado no ponto de encontro, e de cruzamento, entre a área de trabalho social e da área da educação (p. 83). A sua relação com os outros deve pautar-se por comportamentos de respeito e de combate a todas as situações discriminatórias, trabalhando, no dizer de Diaz (2006) para uma socialização terciária (...) ou seja, o processo mediante o qual se pretende que um indivíduo se reintegre na sociedade depois de ter revelado condutas antissociais, associais o dissociais (p. 100), visando a inclusão plena dos diversos atores sociais. Segundo Borda Cardoso (s/d) a definição do papel profissional do Educador Social passa pelo tipo de desempenho que dele se espera, do que ele sabe e é capaz de fazer no quadro das competências para que foi preparado e das respostas emergentes aos desafios laborais (p. 8). Para Nogueira e Solís (2003) o objetivo final das ações do educador social é conseguir a participação de todos os membros do grupo com o fim de transformar a realidade. (...) supõe a criação de um processo de ensino aprendizagem de uma série de valores, atitudes e estratégias que estejam de acordo com o espírito crítico, a participação ativa, a transformação social etc. MATEUS, 2012, p. 61. In: https://bibliotecadigital.ipb.pt/bitstream/10198/7726/1/87335-1-PB.pdf 
reconhecimento, porém, percebe-se também a ausência de consenso de como esse ele deve ser alcançado. É importante ressaltar que a ausência de consenso não deve ser vista como uma barreira intransponível, mas como uma possibilidade de produção de diálogos. Assim, para além de firmar uma conclusão sobre o que é e como deve se formar o educador social, esta pesquisa mostra a necessidade de amadurecimento do debate através da troca de saberes e experiências entre aqueles que mais conhecem sua própria realidade e necessidades, os educadores sociais. $\mathrm{O}$ aspecto da formação do educador social se mostra como central no debate. É importante ter em mente a longa trajetória do educador social para ter sua profissão considerada no Brasil, sendo que o âmbito dos projetos sociais está comumente atrelado a uma ideia de voluntariado. À medida que esse profissional passa a ser valorizado, surgem os questionamentos do que é necessário para alguém ser um educador social. Seria uma questão de formação acadêmica ou de uma bondade inata? Reduzir o educador social a qualquer uma dessas alternativas seria desconsiderar a complexidade de sua profissão e descartar a possibilidade de um debate produtivo e essencial para o desmantelamento estrutural das desigualdades que assolam o Brasil.

Além dos trabalhos citados acima, o GEPEPRIVAÇÃO temos as contribuições de Thais Barbosa Passos, doutoranda que desenvolve pesquisa na área de leitura com o título de "Literatura Carcerária: um princípio de Educação Social na prisão". Os trabalhos de pesquisa de iniciação cientifica de Isabela Bovo Manfrin: "Etnomatemática no ambiente de privação de liberdade" (2020); de Vitor Moura Romeiro: "Pontos ao léu: Geoprocessamento e a responsabilidade da universidade pública com a Educação Prisional” (2020); de Leonardo José A Ribas: “A educação nas prisões das mesorregiões de Presidente Prudente e Araçatuba: a responsabilidade da universidade pública" (2021); de Luisa Sagretti de Souza: “A Inserção escolar de adolescentes após o cumprimento da medida socioeducativa de internação" (2021). Todos os membros citados participam das reuniões semanais do GEPEPRIVAÇÃO.

Ainda, sobre esta pesquisadora coloco que no estado de SP a Supervisão de Ensino abrange todo Sistema de Ensino e se organiza a partir de Decretos e Resoluções. Na Resolução SE 50/2018 estão contidas as atribuições do Supervisor:

O Supervisor de Ensino, lotado na Diretoria Regional de Ensino, desempenha ações de assessoria, planejamento, controle, avaliação e proposição de políticas públicas. Orienta e acompanha escolas públicas, elabora relatórios periódicos de suas atividades relacionadas ao funcionamento das escolas nos aspectos pedagógicos, de gestão e de infraestrutura, propondo medidas de ajuste necessárias, com vistas à constante melhoria do atendimento educacional do sistema de ensino paulista.

No campo administrativo, realiza a orientação, acompanhamento, fiscalização e o saneamento de atos administrativos nas escolas públicas e privadas, de forma individual ou por meio de comissões. No campo pedagógico, presta assessoria, orientação e acompanhamento do planejamento, desenvolvimento e avaliação do ensino e da aprendizagem nas escolas públicas.

A atuação do Supervisor de Ensino está fundamentada nas teorias e práticas educacionais, nas normas legais pertinentes à educação nacional e à educação básica oferecida pelo Sistema 
de Ensino do Estado de São Paulo, no contexto escolar e na concepção de gestão democrática e participativa, com vistas à promoção de um ensino público de qualidade para todos os estudantes.

Na Diretoria de Ensino o Supervisor participa do processo coletivo de construção do plano de trabalho da Diretoria de Ensino, elabora seu plano de trabalho articulado com o Núcleo Pedagógico, bem como acompanha o desenvolvimento de programas de educação continuada propostos pela Secretaria da Educação para aprimoramento da gestão escolar. Realiza estudos e pesquisas, emite pareceres e propõe ações voltadas para o desenvolvimento do sistema de ensino, acompanha a utilização dos recursos financeiros e materiais para atender às necessidades pedagógicas e aos princípios éticos que norteiam o gerenciamento de verbas públicas

ações voltadas à melhoria da atuação da equipe escolar, dos docentes e do desempenho dos alunos, buscando, numa ação conjunta, soluções e formas adequadas ao aprimoramento do trabalho pedagógico e administrativo da escola" (Resolução SE nº 50/2018).

\section{No Artigo 74, do Decreto 64.187/2019, as responsabilidades do Supervisor de Ensino estão} pormenorizadas:

I - exercer, por meio de visita, a supervisão e fiscalização das escolas incluídas no setor de trabalho que for atribuído a cada um, prestando a necessária orientação técnica e providenciando correção de falhas administrativas e pedagógicas, sob pena de responsabilidade [...];

II - assessorar, acompanhar, orientar, avaliar e controlar os processos educacionais implementados nas diferentes instâncias do sistema educacional;

III - assessorar ou participar, quando necessário, de comissões de apuração preliminar e/ou de sindicâncias, a fim de apurar possíveis ilícitos administrativos;

IV - nas respectivas instâncias regionais:

a) participar:

1. do processo coletivo de construção do plano de trabalho da Diretoria de Ensino;

2. da elaboração e do desenvolvimento de programas de educação continuada propostos pela

Secretaria para aprimoramento da gestão escolar;

b) realizar estudos e pesquisas, dar pareceres e propor ações voltadas para o desenvolvimento do sistema de ensino;

c) acompanhar a utilização dos recursos financeiros e materiais para atender às necessidades pedagógicas e aos princípios éticos que norteiam o gerenciamento de verbas públicas;

d) atuar articuladamente com o Núcleo Pedagógico:

1. na elaboração de seu plano de trabalho, na orientação e no acompanhamento do desenvolvimento de ações voltadas à melhoria da atuação docente e do desempenho dos alunos, à vista das reais necessidades e possibilidades das escolas;

2. no diagnóstico das necessidades de formação continuada, propondo e priorizando ações para melhoria da prática docente e do desempenho escolar dos alunos;

e) apoiar a área de recursos humanos nos aspectos pedagógicos do processo de atribuição de classes e aulas;

f) elaborar relatórios periódicos de suas atividades relacionadas ao funcionamento das escolas nos aspectos pedagógicos, de gestão e de infraestrutura, propondo medidas de ajuste necessárias;

g) assistir o Dirigente Regional de Ensino no desempenho de suas funções; $\mathrm{V}$ - junto às escolas da rede pública estadual da área de circunscrição da Diretoria de Ensino a que pertence cada Equipe:

a) apresentar à equipe escolar as principais metas e projetos da Secretaria, com vista à sua implementação; 
b) auxiliar a equipe escolar na formulação:

1. da proposta pedagógica, acompanhando sua execução e, quando necessário, sugerindo reformulações;

2. de metas voltadas à melhoria do ensino e da aprendizagem dos alunos, articulando-as à proposta pedagógica, acompanhando sua implementação e, quando necessário, sugerindo reformulações;

c) orientar:

1. a implementação do currículo adotado pela Secretaria, acompanhando e avaliando sua execução, bem como, quando necessário, redirecionando rumos;

2. a equipe gestora da escola na organização dos colegiados e das instituições auxiliares das escolas, visando ao envolvimento efetivo da comunidade e ao funcionamento regular, conforme normas legais e éticas;

d) acompanhar e avaliar o desempenho da equipe escolar, buscando, numa ação conjunta, soluções e formas adequadas ao aprimoramento do trabalho pedagógico e administrativo da escola;

e) participar da análise dos resultados do processo de avaliação institucional que permita verificar a qualidade do ensino oferecido pelas escolas, auxiliando na proposição e adoção de medidas para superação de fragilidades detectadas;

f) em articulação com o Núcleo Pedagógico, diagnosticar as necessidades de formação continuada, propondo e priorizando ações para a melhoria do desempenho escolar dos alunos, a partir de indicadores, inclusive dos resultados de avaliações internas e externas;

g) acompanhar:

1. as ações desenvolvidas nas horas de trabalho pedagógico coletivo - HTPC (sic), realizando estudos e pesquisas sobre temas e situações do cotidiano escolar, para implementação das propostas da Secretaria;

2. a atuação do Conselho de Classe e Série, analisando os temas tratados e o encaminhamento dado às situações e às decisões adotadas;

h) assessorar a equipe escolar:

1. na interpretação e no cumprimento dos textos legais;

2. na verificação de documentação escolar;

i) informar às autoridades superiores, por meio de termos de acompanhamento registrados junto às escolas e outros relatórios, as condições de funcionamento pedagógico, administrativo, físico, material, bem como as demandas das escolas, sugerindo medidas para superação das fragilidades, quando houver [...]" (Artigo 74, Decreto n 64.187/2019).

O Supervisor é propositor, orientador e formador das equipes escolares. É responsável pela implementação e avaliação de políticas públicas na escola, e ainda, subsidia e orienta a equipe gestora da escola sobre procedimentos da construção coletiva/participativa da Proposta Pedagógica, do Regimento Escolar e do Plano de Gestão. Orienta a eleição de Conselhos de Escola e de outros colegiados, dentro dos pressupostos da gestão democrática e participativa, tal qual é defendido na LDB e no PNE 2014-2024 (Lei 13.005, 2014). Observando alguns itens da Resolução e do Decreto em tela, é possível apreender que a tarefa do Supervisor de Ensino é bastante abrangente e abarca tanto as dimensões administrativas como pedagógicas da gestão educacional, na Secretaria de Estado da Educação, na Diretoria de Ensino e na Escola para que estejam a serviço de uma educação de qualidade para todos. 
Observando a legislação pertinente ao tema, considerando a pesquisa bibliográfica e os documentos levantados com a observação participante nos centros prisionais de atuação do GEPEPRIVAÇÃO, esse trabalho tem como objetivo principal o debate e proposições, em torno da necessidade da construção do PPP das prisões, considerando suas inúmeras especificidades e com vistas a centralidade das políticas educacionais para encaminhar ações com vistas a reintegração. Indico ainda, que o PPP das prisões como gestado pelo GEPEPRIVAÇÃO para além de proposições pedagógicas, propõe uma reorganização do território prisional e suas assistências como objetivado por esta pesquisa, que tem abrangência de mudança da concepção educacional, de organização e da implementação da execução penal. Diante do exposto, aponto que o PPP seja necessariamente denominado Projeto Político Pedagógico das prisões (PPPprisões). A preocupação com a intitulação provém de não permitir confusão com o projeto de privatização dos presídios, conhecido como PPP. ${ }^{57}$

Beccaria (2013) colocou que "é melhor prevenir os crimes do que ter de puni-los. O meio mais seguro, mas ao mesmo tempo mais difícil de tornar os homens menos inclinados a praticar o mal, é aperfeiçoar a educação". (BECCARIA, 2013, p. 118). Acredito, sim que seja uma tarefa colossal implementar ações educacionais em espaços de privação de liberdade em unidades de contenção ou mesmo com perspectiva de reintegração social. Assim, o primeiro passo para um PPPprisão é o entendimento de que as questões que surgem: Quem são nossos alunos? Como formar o sujeito com vistas a transformação e reintegração à essa sociedade que vivemos? Quais os recursos físicos, humanos e financeiros disponibilizados? Como serão organizados os processos de ensino/aprendizagem, monitoramento e avaliação do projeto político pedagógico das prisões? Essas

57 O processo de privatização nos presídios está regulamentado pela Lei $n^{\circ}$ 8.666/1993. À vista disso, percebe-se a realidade do processo de aprisionamento, justificando-se através dos apologistas e do modo de produção burguês, a necessidade da privatização, ocasionado pelo sucateamento e precarização da prisão. Diante do discurso dos apologistas, do sistema de incompetência do Estado e de ingerência para administrar a prisão, a criação da Parceria Público e Privado - PPP (grifo meu) vem consolidar no Brasil, a necessidade de privatização dos presídios brasileiros como uma forma de administrar a superlotação e redução de custos. [...] o lucro e a exploração da força de trabalho carcerária que permanece articulada aos preceitos das empresas privadas como forma de garantir o discurso de "ressocialização". Portanto, de acordo com esses preceitos e conforme os apologistas do sistema do capital, sobretudo, o grande empresariado, defendem a melhor solução para a gerência das prisões [...] "a primeira iniciativa formal para a privatização dos presídios no Brasil foi feita pelo Conselho Nacional de Política Criminal e Penitenciária, em janeiro de 1992. Os argumentos propostos através das regras básicas frisam uma modelo de gestão prisional perfeita (grifo meu), com objetivos de "reabilitação do preso, redução dos gastos públicos e a diminuição da população carcerária", todos, elementos de pano de fundo para subsidiar a geração de lucro. A partir dessa nova ótica de perfeição do modelo de gestão prisional, fora criada a primeira prisão privada no Brasil, mediante a Parceria Público-Privada no município de Ribeirão das Neves, Minas Gerais, em janeiro de 2013. (SOUZA NETO, ARAUJO) 
questões deverão ser levantadas e encaminhadas pela população do território, com representação das assistências, subvencionados por profissionais de educação alocados em um centro educacional.

Abaixo apresento uma possibilidade de atuação conjunta das áreas do conhecimento presentes no território prisional, a partir da necessária articulação e integração entre as diversas áreas de conhecimento e seus profissionais, centrando-as no PPPprisões.

Figura 4 - Organização PPPprisões

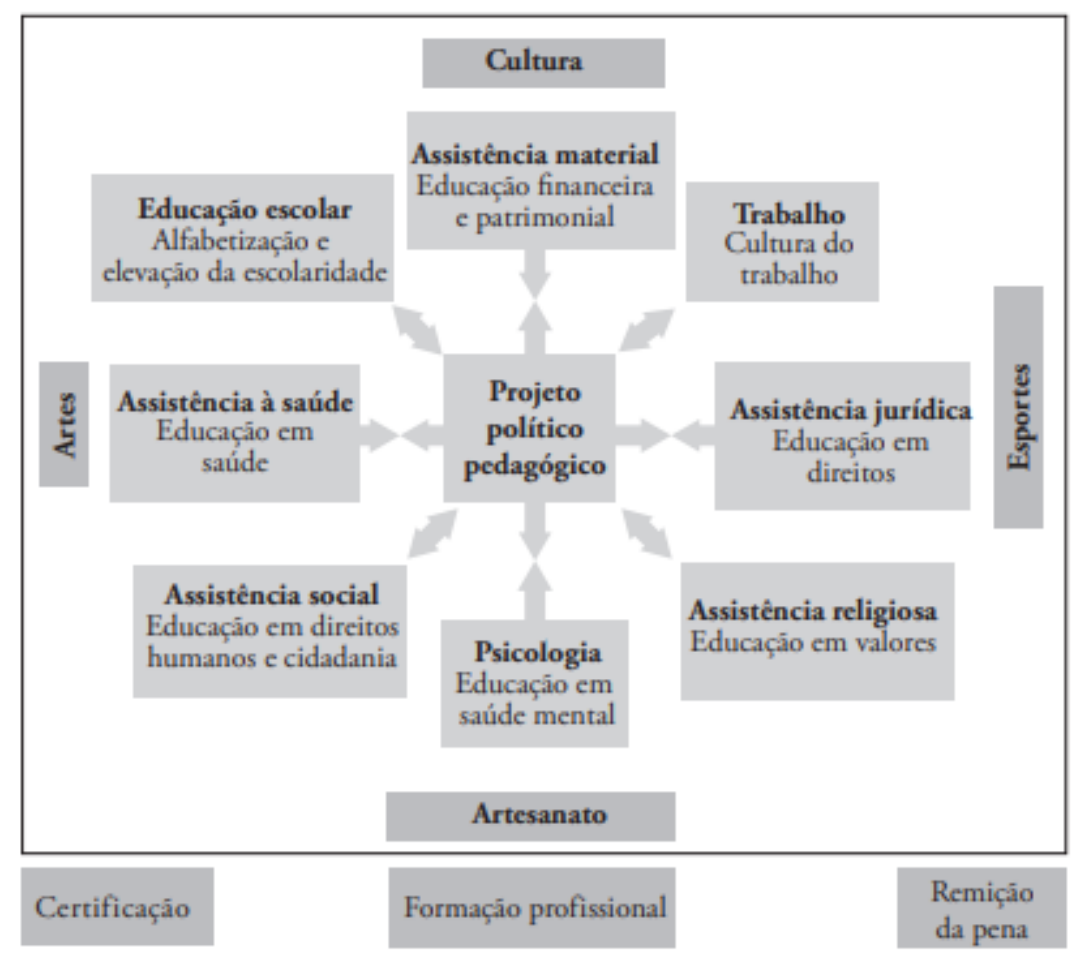

Fonte: Moreira, Oliveira, Silva (2016, p. 32)

A pretensão de reorganizar o território prisional com vistas a centralizar as ações na educação e consequentemente na reintegração, não é uma tarefa simples, posto que o próprio Plano Nacional de Educação já aponta as dificuldades históricas que marcam o campo da educação, afirmando que a complexidade do modelo federativo brasileiro, as lacunas de regulamentação das normas de cooperação e a visão patrimonialista que ainda existe em muitos setores da gestão pública tornam a tarefa do planejamento educacional bastante desafiadora. (Brasil, 2014, p. 01) 
$\mathrm{Na}$ concepção desenvolvida nesta dissertação, planejar educação implica assumir compromissos com o esforço contínuo de eliminação das desigualdades que são históricas no Brasil. Se a educação como um todo tem problemas estruturais no país, a educação no cárcere, recém reconhecida pelas instituições, padece ainda mais. E no que tange a educação nas prisões, aponto que é preciso construir formas orgânicas de colaboração entre os sistemas de ensino e conceber a epistemologia da educação no cárcere, que seja reconhecida como prática e que dialogue com todos os outros modelos e níveis de educação.

Onofre e Julião (2013) colocam que no cárcere, encontram-se duas lógicas opostas sobre o que significa o processo de reabilitação: o princípio fundamental da educação que é, por essência, transformador e a cultura prisional, caracterizada pela repressão, ordem e disciplina, que visa adaptar o indivíduo ao cárcere, e ressaltam que "a função educativa e a função da segurança são dimensões que devem ser abordadas em suas especificidades, não podendo a segunda sobrepor-se à primeira. (ONOFRE E JULIÃO, 2013, p. 63)

Para desenvolver o PPPprisão, é necessário considerar a enorme envergadura que ele propõe, pois estamos lidando com instituições historicamente sucateadas, com mudanças orgânicas, estruturais, de condutas, comportamentos, procedimentos, de execução. Silva, Moreira (2006) colocam que "o PPP das prisões possuiuma dimensão orgânica e estruturante para as ações de múltiplos atores (projeto), impacta a execução penal, os procedimentos disciplinares e a rotina prisional (político) e organiza as condições de ensino, o tempo, o espaço e o currículo (pedagógico)".

\title{
Na Recomendação de Nairobi ${ }^{58}$ :
}

\begin{abstract}
A expressão "educação de adultos" designa o conjunto de processos organizados de educação, qualquer que seja o seu conteúdo, o nível e o método, quer sejam formais ou não formais, quer prolonguem ou substituam a educação inicial dispensada nos estabelecimentos escolares e universitários e sob a forma de aprendizagem profissional, graças aos quais pessoas consideradas como adultas pela sociedade de que fazem parte desenvolvem as suas aptidões, enriquecemos seus conhecimentos, melhoram as suas qualificações técnicas ou profissionais ou lhe dão uma nova orientação, e fazem evoluir as suas atitudes ou o seu comportamento na dupla perspectiva de um desenvolvimento integral do homem e de uma participação no desenvolvimento socioeconômico ecultural equilibrado e independente [...]. (UNESCO, 1976, p. 2).
\end{abstract}

\footnotetext{
58 RECOMENDAÇÃO SOBRE A SALVAGUARDA DOS CONJUNTOS HISTÓRICOS E DA SUA FUNÇÃO NA VIDA CONTEMPORÂNEA, UNESCO, Nairobi (Quénia), 26 de novembro de 1976. In: http://www.patrimoniocultural.gov.pt/media/uploads/cc/salvaguardaconjuntoshistoricos1976.pdf
} 
Apresentadas algumas concepções básicas norteadores, destaco que o PPPprisões deve se desenvolver, obrigatoriamente, a partir da realidade do território, e que deve contribuir para que haja intervenção com perspectivas de transformações da realidade dos sujeitos e do meio, neste caso específico o território prisional, formado por sujeitos imbricados direta ou indiretamente à comunidade do complexo/unidade prisional.

Indico assim, que há necessidade de repensar a organização do trabalho pedagógico utilizando o "tempo" e as "múltiplas relações" do território prisional, ressignificando e avançando no sentido de construção do conhecimento e reintegração dos privados de liberdade, ampliando ainda o processo educacional a todos os sujeitos do espaço prisional, transcendendo a formalização curricular ${ }^{59}$ centrada nas poucas salas de aulas e avançando para a materialização do princípio freiriano da corporificação das palavras pelo exemplo, ou seja, a escola é lócus em que a efetividade do ato educativo reside principalmente nas ações empreendidas, mais que nos discursos e nas teorias (FREIRE, 1987, p. 50).

A educação transcorre todos em os espaços, das salas de aula e em seu entorno e pode ser empreendida por todos aqueles que, intencionalmente, transformam sua rotina de trabalho em ação educativa. Assim, há a possibilidade de considerarmos credenciados, desde que devidamente formados, os servidores e os processos que direta ou indiretamente estejam envolvidos com projetos de formação/educação, independentes de suas frentes de atuação.

A proposta de Projeto Político Pedagógico das prisões ou PPPprisões desenvolvida nesta dissertação aponta uma nova fronteira para execução com vistas a reintegração, pois busca problematizar conceitos e práticas que envolvem o tema. A proposta de PPPprisões aqui apresentada se fundamenta nos dispositivos apontados:

- Da Constituição Federal de 1988, onde, está disposto que, cada uma das escolas, desenvolva autonomia para delinearem um modelo de trabalho com identidade, que esteja em acordo com as suas necessidades e que se torna referencial para todas as instituições escolares. E ainda, como Santos (2018) coloca:

\footnotetext{
${ }^{59}$ Destaco nesse modelo todas as atividades desenvolvidas são consideradas atividades curriculares, assim, não se considera os conceitos atividades curriculares e não curriculares.
} 
A inclusão da dignidade da pessoa na Constituição Federal de 1988 significa não somente que há em seu texto conteúdo ético e moral, mas que o legislador constituinte atribui valor jurídico fundamental ao princípio. É um princípio constitucional de relevância ímpar, tendo em vista que se trata de uma norma jurídica responsável por justificar a existência de todo o ordenamento jurídico. Do princípio da dignidade da pessoa derivam todos os demais princípios éticos de nossa Constituição, que também exercem papel norteador nos demais ramos do Direito (SANTOS, 2018, p. 537-577);

- Da Lei de Diretrizes e Bases da Educação 9394/96 (LDB), que aponta no TÍTULO IV, Organização da Educação Nacional, em seus artigos 12, 13 e $14^{60}$ a incumbência da elaboração da proposta pedagógica das escolas. Dentre as propostas da LDB está ainda, o Artigo $15^{61}$ que discorre sobre a autonomia pedagógica e administrativa, na elaboração do PPP. Ao prever a autonomia das instituições, tem-se o passo principal para que as ações destas unidades considerem efetivamente a realidade disposta de acordo com as características próprias de cada Unidade Escolar;

- Da Resolução No 391 de 10 de maio de 2021, aprovada pelo Plenário do Conselho Nacional de Justiça (CNJ) que regulamenta a remição por estudo, um direito da população carcerária previsto desde 2011, na Lei 7.210/84 (Lei de Execução Penal) onde se delibera que a educação do apenado - e não apenas o trabalho - também possam ser revertido em menos dias da condenação a cumprir. A nova regulamentação atende a uma determinação do Supremo Tribunal Federal (STF) que, ao conceder em março habeas corpus a uma presa de Santa Catarina aprovada no Exame Nacional de Certificação de Competências de Jovens e Adultos (Encceja), reconheceu o direito a remição por leitura conforme Recomendação CNJ n. 44/2013 previu, e incumbiu o CNJ de regulamentar o tema. A resolução estabelece:

[...] procedimentos e diretrizes a serem observados pelo Poder Judiciário para o reconhecimento do direito à remição de pena por meio de práticas sociais educativas em unidades de privação de liberdade. [...] Art. 2o O reconhecimento do direito à remição de pena por meio de práticas sociais educativas considerará as atividades escolares, as práticas sociais educativas não escolares e a leitura de obras

60 Art. 12. Os estabelecimentos de ensino, respeitadas as normas comuns e as do seu sistema de ensino, terão a incumbência de: I - elaborar e executar sua proposta pedagógica; (...) Art. 13. Os docentes incumbir-se-ão de: I participar da elaboração da proposta pedagógica do estabelecimento de ensino; II - elaborar e cumprir plano de trabalho, segundo a proposta pedagógica do estabelecimento de ensino; Art. 14. Os sistemas de ensino definirão as normas da gestão democrática do ensino público na educação básica, de acordo com as suas peculiaridades e conforme os seguintes princípios: I - participação dos profissionais da educação na elaboração do projeto pedagógico da escola; II - participação das comunidades escolar e local em conselhos escolares ou equivalentes.

61 Art. 15. Os sistemas de ensino assegurarão às unidades escolares públicas de educação básica que os integram progressivos graus de autonomia pedagógica e administrativa e de gestão financeira, observadas as normas gerais de direito financeiro público. 
literárias. Parágrafo único. Para fins desta resolução, considera-se: I - atividades escolares: aquelas de caráter escolar organizadas formalmente pelos sistemas oficiais de ensino, de competência dos Estados, do Distrito Federal e, no caso do sistema penitenciário federal, da União, que cumprem os requisitos legais de carga horária, matrícula, corpo docente, avaliação e certificação de elevação de escolaridade; e II - práticas sociais educativas não-escolares: atividades de socialização e de educação não-escolar, de autoaprendizagem ou de aprendizagem coletiva, assim entendidas aquelas que ampliam as possibilidades de educação para além das disciplinas escolares, tais como as de natureza cultural, esportiva, de capacitação profissional, de saúde, dentre outras, de participação voluntária, integradas ao projeto político-pedagógico (PPP) da unidade ou do sistema prisional e executadas por iniciativas autônomas, instituições de ensino públicas ou privadas e pessoas e instituições autorizadas ou conveniadas com o poder público para esse fim.

Art. 3o $\mathrm{O}$ reconhecimento do direito à remição de pena pela participação em atividades de educação escolar considerará o número de horas correspondente à efetiva participação da pessoa privada de liberdade nas atividades educacionais, independentemente de aproveitamento, exceto, quanto ao último aspecto, quando a pessoa tiver sido autorizada a estudar fora da unidade de privação de liberdade, hipótese em que terá de comprovar, mensalmente, por meio da autoridade educacional competente, a frequência e o aproveitamento escolar. Parágrafo único. Em caso de a pessoa privada de liberdade não estar vinculada a atividades regulares de ensino no interior da unidade e realizar estudos por conta própria, ou com acompanhamento pedagógico não-escolar, logrando, com isso, obter aprovação nos exames que certificam a conclusão do ensino fundamental ou médio (Encceja ou outros) e aprovação no Exame Nacional do Ensino Médio - Enem, será considerada como base de cálculo para fins de cômputo das horas visando à remição da pena $50 \%$ (cinquenta por cento) da carga horária definida legalmente para cada nível de ensino, fundamental ou médio, no montante de 1.600 (mil e seiscentas) horas para os anos finais do ensino fundamental e 1.200 (mil e duzentas) horas para o ensino médio ou educação profissional técnica de nível médio, conforme o art. 4o da Resolução n o 03/2010 do Conselho Nacional de Educação, acrescida de 1/3 (um terço) por conclusão de nível de educação, a fim de se dar plena aplicação ao disposto no art. 126, § 5o , da LEP.

Art. 4o $\mathrm{O}$ reconhecimento do direito à remição de pena pela participação em práticas sociais educativas não-escolares, excetuada a leitura, considerará a existência de projeto com os seguintes requisitos: I - especificação da modalidade de oferta, se presencial ou a distância; II - indicação de pessoa ou instituição responsável por sua execução e dos educadores ou tutores que acompanharão as atividades desenvolvidas; III - objetivos propostos; IV referenciais teóricos e metodológicos a serem observados; V - carga horária a ser ministrada e conteúdo programático; VI - forma de realização dos registros de frequência; e VII registro de participação da pessoa privada de liberdade nas atividades realizadas.

[...] Art. 8o Compete ao Poder Judiciário, especialmente aos Grupos de Monitoramento e Fiscalização do Sistema Carcerário, em articulação com os demais órgãos da execução penal e com a sociedade civil, a garantia do direito às práticas sociais educativas a todas as pessoas presas ou internadas cautelarmente e àquelas em cumprimento de pena ou de medida de segurança, independentemente do regime de privação de liberdade ou regime disciplinar em que se encontrem, objetivando: I - assegurar o acesso universal aos livros para fins de remição, seja por meio de permissão para frequência às bibliotecas, seja mediante estratégia de circulação do acervo ou catálogos de livros para requisição; II - fomentar a diversificação de estratégias de renovação do acervo em seus múltiplos formatos e de acesso às bibliotecas das unidades de privação de liberdade, bem como às iniciativas locais de estímulo à leitura e às práticas sociais educativas, inclusive com relação à integração entre projetos de educação não-escolar e o projeto político-pedagógico (PPP) de escolarização; III - assegurar que todas as pessoas privadas de liberdade tenham acesso às informações acerca das práticas sociais educativas realizadas na unidade, bem como às informações sobre os procedimentos para o exercício do direito à remição de pena; IV - fomentar e monitorar a execução das práticas sociais educativas e sua articulação com as políticas de educação escolar, especialmente com os Planos Estaduais de Educação; V - garantir a efetividade das formas de registro e de comunicação entre unidades de privação de liberdade e a Vara de Execução, para fins de remição. (CNJ 44, 2013) 
Ainda, para corroborar com as proposições do PPPprisões, foi apreciada também a Resolução SE 75, de 7/12/2018 que dispõe sobre a organização e o funcionamento dos cursos de Educação de Jovens e Adultos, nos Centros Estaduais de Educação de Jovens e Adultos (CEEJAs). Destaco abaixo algumas deliberações que constam na referida resolução oportunas ao PPPprisões:

Dispõe sobre a organização e o funcionamento dos cursos de Educação de Jovens e Adultos, nos Centros Estaduais de Educação de Jovens e Adultos - CEEJAs [...] Artigo $2^{\circ}$ Os CEEJAs visam a assegurar atendimento individualizado, a alunos, com frequência flexível, sendo organicamente estruturados com o objetivo de atender preferencialmente o aluno, que por motivos diversos, não possui meios ou oportunidade de desenvolver estudos regulares, na modalidade presencial, referentes à(s) etapa(s) da educação básica que ainda não cursou ou concluiu. [...] Artigo $4^{\circ}$ - Os cursos referentes aos anos finais do Ensino Fundamental e do Ensino Médio mantidos pelos CEEJAs terão, em cada nível de ensino, organização curricular abrangente de modo a contemplar todas as disciplinas que integram a Base Nacional Comum e a Língua Estrangeira Moderna na Parte Diversificada do Currículo, cujos conteúdos deverão ser desenvolvidos com metodologias e estratégias de ensino adequadas à característica do curso de presença flexível, mediante ensino individualizado do aluno e a oferta de trabalhos coletivos ou aulas em grupo. Artigo $5^{\circ}$ - O CEEJA somente efetuará matrícula de candidato que comprove ter, no momento da matrícula, inicial ou em continuidade de estudos, de qualquer um dos anos finais do Ensino Fundamental ou SÉRIES do Médio, a idade mínima de 18 (dezoito) anos completos. $\S 1^{\circ}$ - No ato da matrícula, o candidato deverá tomar ciência da necessidade de comprovar: 1 - com relação à frequência ao curso, condições próprias que lhe assegurem o comparecimento obrigatório à realização dos diferentes instrumentos avaliatórios, bem como ao registro de, no mínimo, I (uma) vez por mês, para desenvolvimento das atividades previstas para cada disciplina, objeto da matrícula; 2 - disponibilidade de tempo para realizar estudos, visando à obtenção de conhecimentos essenciais que lhe garantam alcançar resultados positivos na aprendizagem da(s) disciplina(s) que pretende cursar. Artigo $6^{\circ}$ - Observada a exigência do cumprimento da presença mensal e da realização das diferentes avaliações, a duração do intervalo de tempo que intermediará a data da matrícula, inicial ou em continuidade de estudos, e a(s) data(s) prevista(s) para a realização das avaliações, dependerá, exclusivamente, da capacidade e do ritmo de aprendizagem do aluno, bem como de sua disponibilidade de tempo para estudar, de seu interesse, suas necessidades e dos resultados alcançados. Artigo $7^{\circ}$ - A comprovação de resultados satisfatórios no desempenho escolar do aluno, em todas as avaliações/atividades que realizar, corresponderá ao cumprimento da integralização das cargas horárias estabelecidas pelos atos normativos pertinentes, para a duração dos cursos. Artigo 10 - A matrícula de jovens e adultos no CEEJA, independentemente de ser inicial ou em continuidade de estudos, desde que observado o disposto no caput e no $\S 1^{\circ}$, do artigo $5^{\circ}$, desta resolução, poderá ocorrer a qualquer época do ano, devendo ser obrigatoriamente confirmada no início do ano letivo subsequente. Artigo 12 - Poderão ser aproveitados, desde que devidamente comprovados, estudos realizados pelo aluno e concluídos com êxito em: I - cursos de frequência flexível e atendimento individualizado, oferecidos por instituições de ensino públicas ou privadas, inclusive de outros Estados, desde que devidamente validados pelos respectivos órgãos de competência; II - telessalas; III - exames destinados à obtenção de certificação de competências da Educação de Jovens e Adultos, promovidos pelo Governo Federal, por esta Secretaria da Educação ou por instituições autorizadas pelo Conselho Estadual de Educação de São Paulo e de outros Estados; IV - cursos de educação a distância ministrados por instituições de ensino credenciadas pelo Conselho Estadual de Educação de São Paulo ou por instituições de ensino de outros Estados, devidamente credenciadas e/ou reconhecidas pelo respectivo sistema de ensino e validadas pelos órgãos de competência; $\mathrm{V}$ - regime de promoção parcial no ensino regular. Parágrafo único - Caberá à equipe gestora e aos docentes do CEEJA proceder à análise, caso a caso, dos estudos já realizados pelos 
alunos, de forma a garantir que todos os conteúdos das disciplinas do nível de estudos correspondentes sejam devidamente trabalhados. Artigo 14 - As aulas das disciplinas do Centro Estadual de Educação de Jovens e Adultos - CEEJA serão atribuídas em nível de Diretoria de Ensino, a docentes não efetivos e a contratados, desde que devidamente habilitados, inscritos para o processo regular de atribuição de classes e aulas, e igualmente inscritos e credenciados no processo seletivo específico desse projeto. $\S 1^{\circ}-\mathrm{O}$ processo seletivo para credenciamento, de que trata este artigo, será realizado conjuntamente pela Diretoria de Ensino e pela direção do CEEJA, observados os critérios que devem nortear a análise do perfil do docente/candidato, sob os seguintes aspectos: 1 - de comprometimento com a aprendizagem do aluno, demonstrado mediante: a) clima de acolhimento, equidade, confiança, solidariedade e respeito que caracterizam seu relacionamento com os alunos; b) alta expectativa quanto ao desenvolvimento cognitivo e à aprendizagem de todos os alunos; c) preocupação em avaliar e monitorar o processo de compreensão e apropriação dos conteúdos pelos alunos; d) diversidade de estratégias utilizadas para promover o desenvolvimento dos alunos 2 - de responsabilidades profissionais, explicitadas pela: a) disponibilidade de cumprimento da carga horária total de 40 horas semanais, na conformidade do contido no artigo 15 , desta resolução, observado o horário dos turnos de trabalho diário para atendimento dos alunos do CEEJA; b) reflexão sistemática que faz de sua prática docente; c) forma como constrói suas relações com seus pares docentes e com os gestores da escola; d) participação em cursos de atualização e aperfeiçoamento profissional; 3 - de atributos pessoais sinalizados pelos índices de pontualidade, assiduidade, dedicação, envolvimento e participação nas atividades escolares. Artigo 16 - Para o desenvolvimento dos cursos, caberá: I - à Coordenadoria de Gestão da Educação Básica: a) prestar assistência técnico-pedagógica às Diretorias de Ensino; b) acompanhar, controlar e avaliar a implementação do currículo; c) orientar a adequada utilização dos materiais didático- pedagógicos, bem como orientar os procedimentos implementados pela Secretaria da Educação; d) propor, desenvolver e apoiar, em articulação com a Escola de Formação e Aperfeiçoamento dos Professores do Estado de São Paulo - EFAP, programas de capacitação e de formação continuada para os profissionais envolvidos pedagogicamente com os CEEJAs; e) autorizar o funcionamento de novos CEEJAs; II - às Diretorias de Ensino: a) garantir atendimento educacional especializado aos alunos com deficiência, suprindo as necessidades apresentadas com os recursos e equipamentos imprescindíveis à sua superação; b) assegurar aos alunos surdos ou com deficiência auditiva que não se comunicam oralmente, docente qualificado ou com proficiência na Língua Brasileira de Sinais - Libras; c) assegurar o cumprimento das exigências relativas à avaliação do desempenho escolar e à certificação de conclusão de curso; d) analisar e emitir parecer sobre os planos de gestão apresentados pelos CEEJAs; e) oportunizar cursos específicos de atualização e aperfeiçoamento para os professores dos CEEJAs e para os Professores Coordenadores; f) acompanhar a diversidade de composição e organização das avaliações elaboradas pelos professores, avaliando o grau de pertinência às expectativas de aprendizagem; g) acompanhar, por meio do Núcleo Pedagógico, a seleção e a organização das questões das diferentes avaliações, assessorando as equipes gestoras e os docentes dos CEEJAs; III - ao CEEJA: a) efetuar a matrícula dos alunos na Plataforma- Secretaria Escolar Digital - SED e manter atualizado os registros comprobatórios da respectiva escolaridade, assegurando-lhes sua legalidade e autenticidade; b) acompanhar, controlar e avaliar, através da direção, dos professores coordenadores e dos docentes, os resultados obtidos pelos alunos, analisando o desempenho dos cursos com vistas a seu aperfeiçoamento e eficácia; c) divulgar em local de fácil acesso ao público, com a devida antecedência, o calendário escolar do CEEJA; d) expedir e arquivar os documentos de vida escolar; e) efetuar os devidos lançamentos correspondentes à situação de escolaridade final do aluno. (Resolução SE 75, 2018) 
Neste ponto observo que todas as ações de educação pautadas a partir do PPPprisão, necessariamente fundamentadas e homologadas adequadamente, podem ser operadas para remição e certificação.

Foi importante para este trabalho considerar a trajetória, discussões e ideias e encaminhamentos para a concretização da proposta e formato do PPP, como disposto na LDB. Como já comentado, houve um caminho de ampla discussão do processo educativo, iniciado após a Lei da Anistia $^{62}$, entre educadores, movimentos sociais, sindicatos, comunidade, que tinham entre as suas referências, Paulo Freire (1977), que dentre outras tantas contribuições para o projeto político pedagógico das escolas, destaco a indicação que deu aos grupos que encaminhavam proposições, de que não há projetos pedagógicos neutros ou desvinculados do contexto que está inserido, caso o seja, não é PPP.

\begin{abstract}
Não devemos chamar o povo à escola para receber instruções, postulados, receitas, ameaças, representações e punições, mas para participar coletivamente da construção de um saber, que vai além do saber de pura experiência feito, que leve em conta as suas necessidades e o torne instrumento de luta, possibilitando-lhe transformar em sujeito de sua própria história (...) uma escola pública popular não é apenas aquela à qual todos têm acesso, mas aquela de cuja construção todos podem participar. Uma escola com uma nova qualidade baseada no compromisso, numa postura solidária, formando a consciência social e democrática. Nela "todos os agentes" (grifo meu), e não só os professores, possuem papel ativo dinâmico, experimentando novas formas de aprender, de participar, de ensinar, de trabalhar, de brincar e de festejar. (FREIRE, 1977, p. 8-10).
\end{abstract}

O PPP é um expediente que se constrói constantemente e com aporte de intencionalidade, seu desenvolvimento é um processo empírico, que comporta ideais, valores, crenças, princípios e não apenas conhecimento sistematizado. É através do projeto político pedagógico que a Equipe Gestora organiza suas metas e ações, elaboradas de acordo com sua característica, identidade, valores, metas e objetivos, e ainda contando com atuação e compromissos de todos que estão inseridos no processo

62 Em 28 de agosto de 1979, o presidente João Baptista Figueiredo concedeu o perdão aos perseguidos políticos (que a ditadura militar chamava de subversivos) e, dessa forma, pavimentou o caminho para a redemocratização do Brasil. Fonte: Agência Senado. https://www12.senado.leg.br/noticias/especiais/arquivo-s/ha-40-anos-lei-de-anistia-preparoucaminho-para-fim-da-ditadura 
educativo, com ampla participação e responsabilização dos envolvidos no cumprimento das metas projetadas.

Destaco ainda, constitutivos importantes, apontados por mim, como necessários, tanto no encaminhamento da construção, como na importância da idealização da concepção do PPP para a implementação nas instituições e que também são medulares do PPPprisões:

1. O desenvolvimento de educação compromissada com a formação integral do educando, considerando a realidade escolar e a busca por uma educação com qualidade social.

\begin{abstract}
A escola de qualidade social é aquela que atenta para um conjunto de elementos e dimensões socioeconômicas e culturais que circundam o modo de viver e as expectativas das famílias e de estudantes em relação à educação; que busca compreender as políticas governamentais, os projetos sociais e ambientais em seu sentido político, voltados para o bem comum; que luta por financiamento adequado, pelo reconhecimento social e valorização dos trabalhadores em educação; que transforma todos os espaços físicos em lugar de aprendizagens significativas e de vivências efetivamente democráticas.(SILVA, 2009, p 221).
\end{abstract}

2. As rupturas com o que está estruturado para o momento, para arriscar-se numa nova perspectiva, que se constituirá após o término do processo de mudança, configurando estruturas e mudanças esperadas. Um projeto educativo pode ser tomado como promessa frente a determinadas rupturas. As promessas tornam visíveis os campos de ação possível, comprometendo seus atores e autores. (GADOTTI, 1994, p. 579).

3. A sua natureza essencialmente política, confrontante, de compromisso com a formação do cidadão para um tipo de sociedade (VEIGA, 1998. p. 12)

4. É um projeto de natureza democrática, pois rompe com a rotina do mando impessoal e convida a todos a participar de sua elaboração, preconiza a racionalização da burocracia que permeia o interior das escolas, diminuindo os efeitos fragmentários da divisão do trabalho que reforça as diferenças e hierarquiza os poderes de decisão (VEIGA, 1998. p.13-14).

Neste ponto da pesquisa, a partir das fontes analisadas (desenvolvimento de pesquisas e ações do GEPEPRIVAÇÃ̃O ${ }^{63}$, da bibliografia estudada, da legislação pertinente ao tema e da observação

63 O Projeto Político Pedagógico da Educação em Prisões de Marineila Aparecida Marques; O papel e a função das Escolas Vinculadoras na Educação em Prisões no Estado de São Paulo de Letícia Camile de Souza Ananias; A Escola Vinculadora para atendimento à Educação em prisões no Estado de São Paulo de Livia Tupinambá Mattiello; A atuação do educador social na rede pública de ensino na cidade de São Paulo de Anabel Grimm e Araújo; Literatura Carcerária: um princípio de Educação Social na prisão de Thais Barbosa Passos; Etnomatemática no ambiente de privação de liberdade de Isabela Bovo Manfrin; Pontos ao léu: Geoprocessamento e a responsabilidade da universidade pública com 
participante por mim desenvolvida) apresento as metodologias e práticas de educação que buscam alterações significativas para a população do território prisional, ressignificando a cultura e a organização das Unidades Prisionais no que tange a educação e a reintegração social.

Atualmente, cada Estado brasileiro possui conjunturas específicas tanto na educação quanto no seu sistema penitenciário, mas há documentos de referência que podem subsidiar a formulação dos seus respectivos projetos. São eles:

1) Plano Estadual de Educação - nos Estados em que existe, é pertinente verificar se ele faz alguma referência à educação em prisões.

2) Plano Diretor do Sistema Penitenciário - entre suas 22 metas, merece atenção a Meta 15 (educação e profissionalização), na qual se faz o detalhamento quanto ao nível de escolaridade de toda a população prisional no Brasil.

3) Plano Operativo Estadual de Saúde no Sistema Penitenciário desdobramento do Plano Nacional de Saúde no Sistema Penitenciário, que coloca a atenção à saúde do preso como atribuição do Sistema Único de Saúde (SUS).

4) Deliberações do Conselho Estadual de Educação sobre a oferta da educação em prisões ou, analogamente, sobre educação de jovens e adultos e educação técnica e profissional.

Percebemos que a construção de uma política de educação para as pessoas em privação de liberdade, marcos e interfaces políticos e institucionais estão dispostos. Cabe, então, aos seus atores (Ministérios e órgãos estaduais gestores da educação e da administração penitenciária, bem como organizações da sociedade civil, do judiciário e representações das pessoas privadas de liberdade) empreender os esforços e encaminhar os avanços necessários para implementação das normativas já construídas e ainda, cabe a avaliação e novas propostas para o desenvolvimento e implantação mecanismos de execução, formação profissional e organização do território para que comecemos a transpor as barreiras, a ineficiência o tímido atendimento escolar, já diagnosticadas no campo da assistência prisional

\footnotetext{
a Educação Prisional de Vitor Moura Romeiro; Arte e Educação: significados e sentidos das práticas artísticas e culturais na prisão e Entre Versos e Vigas: a poesia como ferramenta de educação social para pessoas em privação de liberdade, ambos de João Pedro Rodrigues Innecco.
} 
A proposta do GEPEPRIVAÇÃO é a de que o projeto das unidades prisionais abarque todo o território prisional, considerando que toda população que está inserida nele e que esteja envolvida em programas de assistências, sejam participes do PPP. Freire coloca,

\footnotetext{
Participar ativamente na história, na sociedade, na transformação da realidade se não for ajudado a tomar consciência da realidade e da sua própria capacidade de transformar [...] Ninguém luta contra forças que não entende, cuja importância não meça, cujas formas de contorno não discirna; [...] Isto é verdade se, se refere às forças sociais[...] A realidade não pode ser modificada senão quando o homem descobre que é modificável e que ele o pode fazer." (PAULO FREIRE, 1999, p 48)
}

Enfatizo que não há educação específica a ser desenvolvida na prisão, não é preciso inventar a educação das prisões, no entanto, é sim necessário, matrizes pedagógicas e metodologias diversificadas posto que o aluno do território prisional são pessoas que têm experiências de aprendizagem e competências desenvolvidas. "Todos têm alguma experiência de aprendizagem positiva ou negativa, vivida conscientemente ou não, assim, a educação na prisão jamais parte do nada." (MAYER, 2011, p. 50)

SILVA, MOREIRA (2006) também discorrem sobre as especificidades da EJA prisional e que há necessidade de adequada formação de professores, de especialização dacarreira, de desenvolvimento de ações pedagógicas e de elaboração de indicadores de avaliação que deem conta de apreender a multiplicidade de fatores presentes na relação de ensino e aprendizagem dentro da prisão.

Postas essas considerações, como premissas, reitero a necessidade de considerarmos os eixos da educação social, que obtém fundamentos científicos na pedagogia social, como balizadores do PPP das prisões, pois a educação que vislumbramos é a de transformar a práxis e organização do território prisional a partir de propostas e diretrizes que considerem todo o espaço da assistência para o desenvolvimento de projetos e ações da educação.

Considero a educação social princípio norteador no desenvolvimento do Projeto Político Educacional das Prisões. Elenco alguns eixos centrais para desenvolvimento da educação social na esfera de abordagem que interessa ao PPP das prisões:

a) o âmbito socioeducativo é o espaço disciplinar em que se realiza a práxis da educação social que, do mesmo modo que outras disciplinas sociais, exerce a mediação para prevenir as situações de escassez e garantir a promoção dos indivíduos. 
b) a educação social pode corrigir a concepção clássica de institucionalização, a educação social não se esgota no não formal, muito pelo contrário, deve abarcar todos os espaços e todos os momentos, já que o homem se aperfeiçoa em qualquer âmbito e ao longo de toda a sua vida. A educação social promove estratégias didáticas de caráter instrumentalista, cujo meio é a autonomia pessoal, independentemente do contexto no qual se encontra o indivíduo.

c) a educação social é uma prática social que medeia a socialização dos indivíduos, que desenvolvendo ação educativa atuam sobre a sociedade.

d) a educação social deve promover no indivíduo a sensibilização e tomada de consciência de si e do meio (território). A educação social deve intervir naquelas circunstâncias que geram situações de necessidade nas pessoas, (FERNANDEZ, apud DIAS, 2006, p 102).

Acrescento abaixo, mais alguns pontos essenciais para se considerar na condução de ações e projetos do PPPprisões:

e) interação dos presos com a população do território prisional, família e sociedade;

f) redução das assimetrias nas relações entre os presos, considerando vulnerabilidades físicas e psíquicas;

g) otimização das relações pessoais com o intuito de melhorar o clima social da prisão e de obter espaços amplos de solução coletiva de conflitos e problemas que evitem soluções violentas e autodestrutivas;

h) possibilitar uma observação e operacionalização racional dos programas e benefícios baseados nas necessidades e demandas do preso $^{64}$;

64 A Unidade Prisional deve se preocupar em realizar procedimentos adequados à identificação das pessoas privadas de liberdade em função de suas trajetórias e potenciais, com mecanismo que considerem encaminhamentos fundados no trato humanitário e equitativo. Ainda, acrescento a este tópico a observação de que A Organização das Nações Unidas (ONU) aprovou em 14 de dezembro de 1990 Resolução nº 45/110 intitulada Regras Mínimas para a Elaboração de Medidas não Privativas de Liberdade, também conhecida como Regras de Tóquio, orientando a todos os países a aplicação de sanções alternativas à prisão, reservando-se o encarceramento somente para atos de maior poder ofensivo ou para agentes que apresentem maior grau de periculosidade. Segundo o espírito desta Resolução, o Brasil deveria encontrar urgentemente outras formas de responsabilização criminal da mulher sentenciada pelo cometimento de crimes que não seja o encarceramento. A concessão (SIC)da Lei $n^{\circ} 11.942$ para que a mulher possa ficar com seus filhos pequenos dentro da 
i) elaboração e implantação de todas as atividades desenvolvidas em diferentes espaços e tempo, considerando-os como projetos educacionais de aprendizagens individuais e coletivas;

j) considerar todas as atividades desenvolvidas nas assistências, partir de experiências piloto, etapas e modalidades diversificadas de educação;

k) reconhecer o território prisional como espaço educacional;

k) buscar sinergia entre as ciências assistências que se assentam no território prisional;

1) envolver secretarias de educação, administração penitenciária e assistência social para formação continuada, organização, fomento, elaboração e avaliação dos projetos políticos pedagógicos das prisões;

m) criação de cargos específicos na carreira de oficial de execução penal dos estados, na função de Diretor e na função de coordenador pedagógico para exercício das funções no setor de educação, com definição de perfil adequado, curso superior e remuneração condizente;

n) criação de normas, considerando a LDB e LEP, planejadas e acompanhadas pela educação, nos turnos matutino, vespertino e noturno e articuladas com outras assistências para desenvolvimento de projetos educacionais;

o) assegurar as atualizações da oferta das modalidades de educação escolar, educação profissional, certificações e remição, pelo estudo, trabalho, projetos;

p) ampliar a oferta de curso de educação profissional buscando diferentes parcerias, assegurando financiamento condizente com as especificidades dos cursos de educação profissional, de modo a promover condições adequadas de manutenção, expansão e aperfeiçoamento dessa modalidade de ensino.

prisão durante o cumprimento da sentença só agrava o problema e impõe ao município uma atribuição que distorce suas finalidades originárias 
Alguns dos itens acima citados serão a seguir abordados com maior acuidade. Ainda, lembro, que em seu bojo, o PPP das prisões propõe que o território prisional seja iminentemente pedagógico, um espaço que deve transfundir a defesa e promoção dos direitos humanos e o respeito à dignidade, fomentando ações e estratégias de transformação desse espaço de contenção e meramente punitivista para o de formação dos sujeitos, com vistas a reintegração. O PPP das prisões propõe que o território prisional precisa ser ressignificado, transformando-se como espaço potencialmente pedagógico.

Expostos alguns critérios que considero básicos para encaminhamentos do PPP, destaco alguns pontos operacionais que, a partir de experiencias e levantamentos do GEPEPRIVAÇÃO, acredito que sejam meios para as transformações almejadas na construção do PPP das prisões.

I. Envolvimento de todo território prisional na concepção coletiva do PPPprisões.

Os profissionais que atuam em prisão devem, necessariamente, contribuir para transformá-la numa comunidade de aprendizagem. O PPPprisões deve conter deliberações quanto as ações de formação dos profissionais que atuam no território e ainda ações que busquem alcançar a todos no sentido de se apropriarem culturalmente da concepção de educação no cárcere e desenvolverem práticas que levem ao desenvolvimento das ações de convívio e reintegração social.

Não restrita às salas de aula, tampouco instrumentalizada para adaptar os sujeitos à vida em
privação de liberdade. (...) A integração entre a educação escolar e outras formas não
escolarizadas de aprendizagem tornam-se necessárias, considerando que: Políticas e medidas
legislativas para a educação de adultos precisam ser abrangentes, inclusivas e integradas na
perspectiva de aprendizagem ao longo da vida, com base em abordagens setoriais e
intersetoriais, abrangendo e articulando todos os componentes da aprendizagem e da
educação (UNESCO e Ministério da Educação, 2006, p. 09). 89

Ainda, é necessário o planejamento coletivo das ações nos níveis curricular/extracurricular, didático, metodológico, pedagógico e elaboração de projetos educacionais a serem desenvolvidos no território prisional. Todas as ações inseridas e devidamente apontadas no PPPprisões, SILVA, MARQUES (2021) colocam,

É necessário dar eficácia ao princípio do regime de colaboração, tão enfaticamente colocado no artigo 211 da Constituição Federal de 1988, na Lei de Diretrizes e Bases da Educação Nacional (LDB), de 1996, nos Arranjos de Desenvolvimento da Educação (ADEs), na Resolução CNE/CEB 1, de 23 de janeiro de 2012, na Lei de Consórcios, de 6 de abril de 2005, no Decreto ${ }^{\circ}$ 6.017, de 17 de janeiro de 2007, no artigo $7^{\circ}$ do Plano Nacional de Educação (PNE) (Lei n 13.005, de 25 de junho de 2014), que dizem: “A União, os Estados, o Distrito Federal e os municípios atuarão em regime de colaboração, visando ao alcance das 
metas e à implementação das estratégias objeto deste Plano. Ora, a Educação é marcada pela intencionalidade e para isto se serve do espaço, do tempo, da progressividade dos conteúdos, do método, da didática, do controle e da avaliação e visa alcançar seus objetivos em médios e longos prazos e é preciso entender nesta nova arquitetura pedagógica as atribuições e competências dos entes nomeados na Resolução CNE/CEB que baliza este estudo. Neste sentido, a atribuição do município na oferta da Educação em Prisões deveria ser na oferta da Educação de Jovens e Adultos, especialmente em relação à alfabetização e ao Ciclo I do Ensino Fundamental e não em relação à Educação (SILVA, MARQUES, 2021, p 59)

II. Centro pedagógico e administrativo alocado na Unidade prisional que trabalhe operacionalizando todas as ações educativas do território, tanto no aspecto burocrático, como na implementação dos projetos

A partir da análise participante de classes escolares nas prisões e das produções acadêmicas sobre o tema, aponto que para o desenvolvimento do PPPprisões nos moldes que ele é proposto, é essencial um centro pedagógico locado na Unidade Prisional. FREIRE (1991) bem coloca, que a construção de projeto político pedagógico não pode ser feita, elaborada, pensada por uma dúzia de iluminados cujos resultados são encaminhados em forma de pacotes para serem executados de acordo ainda com as instruções e guias igualmente elaborados pelos iluminados. (FREIRE, 1991, p. 27). Não é possível pensar em projetos para o território prisional sem estar alocado no território e desenvolvendo ações a partir da realidade em que está inserida e com autonomia.

Como já visto, atualmente temos desenvolvidos pelos Estados vários modelos em atendimento à legislação federal ${ }^{65}$ que delibera que as Secretarias de Estado de educação se responsabilizem pela implementação de educação básica nas Unidades Prisionais.

No entanto, a ausência de um quadro administrativo próprio para atender a prisão, inexistência de uma direção específica, de equipe pedagógica, de coordenação e de supervisão é impensável nos moldes de um PPPprisões.

65 Conselho Nacional de Política Criminal e Penitenciária (CNPCP). Resolução no 3, de 11 de março de 2009. Dispõe sobre as Diretrizes Nacionais para a Oferta de Educação nos Estabelecimentos penais. Diário Oficial da União, Brasília, Seção 1, p. 22, 25 mar. 2009. 
Em minha atuação como Supervisora de Ensino e com as pesquisadoras do GEPEPRIVAÇÃO, Letícia Camile de Souza Ananias e Lívia Tupinambá Mattiello, a partir da observação participante em duas Unidades Prisionais, em classes geridas por escolas vinculadoras, observam-se inúmeras problemáticas e entraves por não haver equipes pedagógicas nas unidades prisionais.

Não cabe a esta dissertação traçar a avaliação de cada modelo de escolas/classes prisionais desenvolvido nos Estados, mas cabe aqui colocar, como já ressaltado, que é impossível desenvolver o PPPprisões, nos moldes aqui proposto, sem que haja a criação de centros educacionais, que devem necessariamente estar alocados nas unidades prisionais e com um quadro composto de educadores, contando ainda com no mínimo um Diretor Educacional e um Coordenador Pedagógico. É importante as Unidades preocuparem-se com a demanda a ser atendida e contratarem profissionais respeitandose módulos de atendimento. Não é possível ainda, conduzir a elaboração de um PPPprisões, sem profissionais qualificados e em número adequado. SILVA. MARQUES (2021, p 61) apontam a importância de articulação entre as secretarias e órgãos de governo, a criação de infraestrutura e logística, a organização das carreiras profissionais; a definição de atribuições e competências e planificação de oferta, fiscalização e avaliação da Educação nas prisões.

Todos os profissionais que atuam em prisão devem contribuir para transformá-la numa comunidade de aprendizagem, na qual o espaço escolar desempenha o papel de "ponto de encontro" e sistematização dessa multiplicidade de atores, o que exige, por seu turno, a compreensão, formação e colaboração com os profissionais que atuam neste espaço escolar:

\footnotetext{
Por se tratar de um espaço com características próprias, regido por normas e regras específicas e que privilegiam a manutenção da ordem estabelecida pelo sistema prisional, o professor deve se apropriar desses saberes (que não são discutidos em sua formação inicial), fazendo-se necessário um processo de ambientação (...) cabe aos professores experientes e à equipe multidisciplinar que atende os indivíduos em privação de liberdade, promover situações que aproximem os iniciantes das regras da casa e os façam conhecer os limites e possibilidades para desenvolver as ações educativas na sala de aula (Onofre e Julião, 2013, p. 62-63).
}

Não restrita às salas de aula, tampouco instrumentalizada para adaptar os sujeitos à vida em privação de liberdade, a educação em prisões deve estar articulada, também, a outras iniciativas, tais 
como a formação para o mundo do trabalho, o desenvolvimento pessoal, a formação de repertórios socioculturais, dentre outros.

III. Organização do PPPprisões: metas de longo prazo

Como o PPPprisões trabalha com a intenção de transformação conjuntural do território prisional, "consiste em projeto de médio e longo prazo, trabalha em função de objetivos e metas próprios, que devem ser compatíveis com os objetivos e metas da reabilitação penal” (SILVA, MOREIRA, 2006). Assim, é necessário que haja um período mais longo para a implementação dele, proponho que seja um PPP quadrienal, mas avaliado anualmente, corrigindo rumos caso se faça necessário.

Neste ponto ressalto que o PPPprisões deverá estar embasado por legislação vigente, que indique a necessidade de documentos legais e apontamentos específicos para a organização escolar. O PPPprisões será, então, documento próprio do território prisional, alinhado ao Plano de Gestão dos Estados, ou direcionado a partir de um modelo único. Em São Paulo, o PARECER CEE nº 67/98 CEF/CEM de 18-03-98 aponta alguns itens que considero básico, após adequação, constar no Projeto político pedagógico das prisões:

Artigo 29 - O plano de gestão é o documento que traça o perfil da escola, conferindo-lhe identidade própria, na medida em que contempla as intenções comuns de todos os envolvidos, norteia o gerenciamento das ações intraescolares e operacionaliza a proposta pedagógica. $\S$ $1^{\circ}$ - O plano de gestão terá duração quadrienal e contemplará, no mínimo: I - identificação e caracterização da unidade escolar, de sua clientela, de seus recursos físicos, materiais e humanos, bem como dos recursos disponíveis na comunidade local; II - objetivos da escola; III - definição das metas a serem atingidas e das ações a serem desencadeadas; IV - planos dos cursos mantidos pela escola; $\mathrm{V}$ - planos de trabalho dos diferentes núcleos que compõem a organização técnico- administrativa da escola; VI - critérios para acompanhamento, controle e avaliação da execução do trabalho realizado pelos diferentes atores do processo educacional. $\S 2^{\circ}$ - Anualmente, serão incorporados ao plano de gestão anexos com: I agrupamento de alunos e sua distribuição por turno, curso, série e turma; II - quadro curricular por curso e série; III - organização das horas de trabalho pedagógico coletivo, explicitando o temário e o cronograma; IV- calendário escolar e demais eventos da escola; V - horário de trabalho e escala de férias dos funcionários; VI - plano de aplicação dos recursos financeiros; VII - projetos especiais. Artigo 30 - O plano de cada curso tem por finalidade garantir a organicidade e continuidade do curso, e conterá: I - objetivos; II - integração e sequência dos componentes curriculares; III - síntese dos conteúdos programáticos, como subsídio à elaboração dos planos de ensino; IV - carga horária mínima do curso e dos componentes curriculares; $132 \mathrm{~V}$ - plano de estágio profissional, quando for o caso. $\S 1^{\circ}$ - Em se tratando de curso de educação profissional será explicitado o perfil do profissional que se pretende formar. $\S 2^{\circ}$ - O plano de ensino, elaborado em consonância com o plano de curso constitui documento da escola e do professor, devendo ser mantido à disposição da direção e 
Supervisão de Ensino. Artigo 31- O plano de gestão será aprovado pelo conselho de escola e homologado pelo órgão próprio de supervisão. (SÃO PAULO, 1998)

IV. Organização de planos estratégicos: ações do território prisional desenvolvidas a partir de projetos com apontamento de metas, objetivos e estratégias

Item fundamental do PPPprisões, que como já sabemos é um documento dinâmico e com identidade, é a orientação de inclusão de anexos anuais apresentando plano de ensino contendo metas de curto prazo, objetivos e estratégias educacionais para o ano em curso, através de projetos desenvolvidos pelas Unidades, aprovados pelo centro Pedagógico das Unidades, considerando o tempo e a interatividade de todos os setores da assistência: educação, trabalho, saúde, segurança pública e serviço social.

Para Boutinet (2002, p. 238) construir um projeto é arquitetar toda uma metodologia de apreensão das oportunidades. Os projetos do território prisional, devem necessariamente contemplar todos os saberes que estão constituídos nas ciências assistências alocadas no território prisional, considerando como encaminhamento fundamental para sua constituição a perspectiva educacional, visando o desenvolvimento de múltiplas competências que capacitem o aluno a ler a complexidade de seu universo.

Outro ponto importante a ser considerado é o envolvimento das diferentes áreas que articulem propostas para desenvolvimentos pedagógicos plurais, e com interação entre as áreas. Como muito bem Lenoir (1998) colocou sobre interdisciplinaridade, "uma forma de relacionar, articular e integrar (grifo meu) os conhecimentos desenvolvidos no processo de ensino e aprendizagem, integrados ao processo de ensino e de aprendizagem significativas e permitindo o estabelecimento de inter-relações entre os conhecimentos científicos, disciplinares e destes com o cotidiano, de uma forma fundamentada e planejada. Qualquer que seja o campo de operacionalização, ele poderá ser investigado (pesquisa), professado (ensino) ou praticado (aplicação). [...] No domínio da educação, a interdisciplinaridade escolar pode ser, portanto, objeto de pesquisa, ser ensinada e praticada." (LENOIR, 1998, p. 47-49). Aqui, não nos referimos às disciplinas escolares, mas a projetos educacionais que considerem temas significativos para o desenvolvimento das múltiplas aprendizagens apontadas como centrais no PPP. 
No campo do território prisional, estamos nos referindo às ações que integram as assistências e que sejam propostos projetos estabelecendo convergência e complementaridade entre as diferentes áreas. Lembro que os procedimentos metodológicos para a elaboração de um projeto não se apresentam de forma fixa, mas, segundo Boutinet (2002, p. 238), geralmente apresentam três etapas que se mostram essenciais para sua elaboração e execução: análise e diagnóstico da situação; esboço de um projeto possível; concepção de estratégias a serem utilizadas. Assim como Boutinet (2002), considero que as ações pedagógicas que se fundamentam em projetos devem respeitar quatro premissas básicas: unicidade da elaboração e da realização, integração entre os que concebem o projeto e os que o realizam; singularidade de uma situação a ser ordenada, significando que a resposta a uma questão depende do contexto e será delimitada; gestão da complexidade e da incerteza, posto que os projetos são destinados a administrar a indeterminação de uma situação problemática que deve ser tomada em toda a sua complexidade, exploração de oportunidades em um ambiente aberto, que implica um olhar diferenciado sobre a realidade para identificar algo a fazer que somente possa ser realizado a partir da ação concreta dos sujeitos. "A estratégia é encarregada de governar a ação em relação ao projeto e às circunstâncias [...] a escolha estratégica é sempre feita em função de uma dupla referência: o projeto entrevisto e a situação analisada" (BOUTINET, 2002, p. 234-239)

Como foi dito, cada Estado brasileiro possui conjunturas específicas tanto na Educação quanto no seu sistema, assim ressalto que no âmbito de um plano estadual não há uma solução única para oferta da Educação em prisões. A produção de um PPP prisões deve necessariamente também contemplar as especificidades com a construção de projetos que melhor respondam as metas e objetivos dentro do Estado. SILVA, MARQUES (2021) apontam como um dos exemplos dessas especificidades:

Durante o processo de elaboração dos planos estaduais para a Educação em estabelecimentos penais nos estados de Mato Grosso do Sul, Santa Catarina e Mato Grosso, a análise dos dados de escolarização dos presos apontaram para a necessidade de que a Educação de Jovens e Adultos a ser oferecida assumisse modelagens diversas para atender às diferentes necessidades de homens e mulheres presos. A primeira modelagem, para contemplar os presos que não são alfabetizados ou não exercitaram o direito constitucional à Educação Básica de nove anos foi, prioritariamente, nos sentidos de alfabetização e de elevação da escolaridade. (SILVA, MARQUES, 2021, p. 63) 
Muitos estudos, desde pesquisas acadêmicas, observações diretas por parte de educadores profissionais, relatórios produzidos por investigações judiciárias e parlamentares até monitoramentos realizados por entidades de defesa dos direitos humanos, e também minha perspectiva a partir da supervisão dos centros de detenção e estímulo de trabalhos com projetos na educação regular e projetos extra escolares, assinalam respostas positivas quanto ao que se propõe, desenvolvimento de habilidades, socialização, capacitação técnica profissional. Podemos citar como exemplo, projetos desenvolvidos por professores das classes regulares locados nos centros de detenção ${ }^{66}$. Trouxe no começo desse tópico, como exemplo o trabalho desenvolvido por João Innecco e Margarete, membros do GEPEPRIVAÇÃO, que desenvolveram projetos nos centros de progressão e detenção provisória. Em São Paulo, poderíamos citar outras centenas de projetos desenvolvidos pelas Unidades Prisionais, alguns divulgados pela SAP:

Quadro 5 - Projetos desenvolvidos pelas Unidades Prisionais

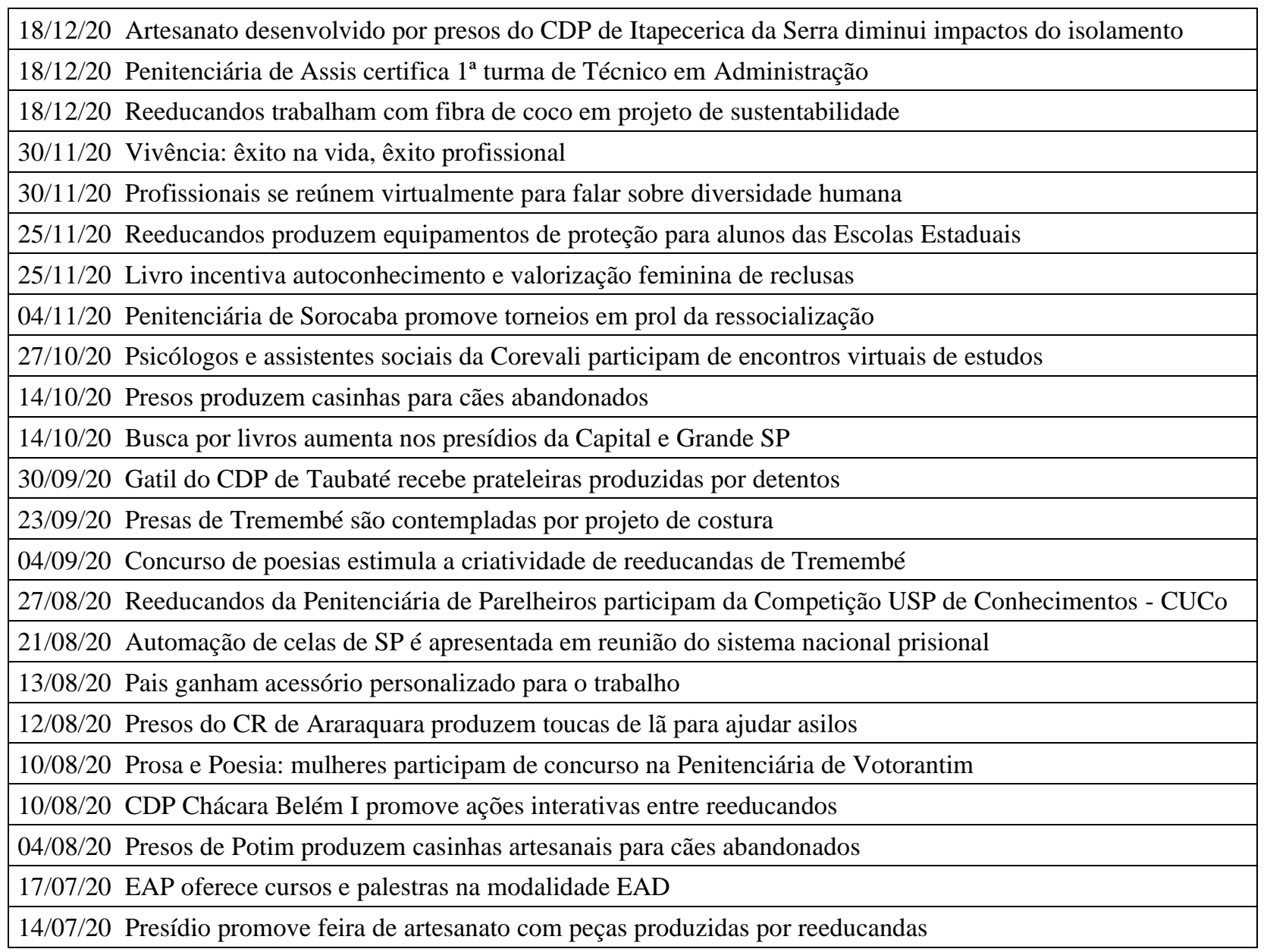

66 Alguns desses projetos são citados no livro Didática no Cárcere II, 


\begin{tabular}{|c|c|}
\hline $24 / 06 / 20$ & Reeducandos reformam unidades prisionais de Porto Feliz e Sumaré \\
\hline $27 / 05 / 20$ & Em tempos de pandemia, crochê funciona como terapia para sentenciadas \\
\hline $06 / 05 / 20$ & Cresce número de presos na Olimpíada de Matemática \\
\hline $04 / 05 / 20$ & CAEF's em SP firmam parceria com projeto social durante a pandemia de Coronavírus \\
\hline $22 / 04 / 20$ & Jornada da Penitenciária I de São Vicente destaca a importância da cidadania \\
\hline $16 / 04 / 20$ & Cresce o número de beneficiados com a remição de pena pela leitura na CRC \\
\hline $07 / 04 / 20$ & Penitenciária de Mogi Guaçu recebe doação de livros do Instituto Federal de Minas Gerais \\
\hline $07 / 04 / 20$ & Projeto da Unifesp promove a Remição Penal pela Leitura na Penitenciária de Guarulhos \\
\hline $07 / 04 / 20$ & Detento é palestrante em evento voltado à leitura \\
\hline $01 / 04 / 20$ & Presos de Potim passam por exames de saúde durante Jornada \\
\hline $30 / 03 / 20$ & Reeducandos do CDP de Limeira participam de curso profissionalizante \\
\hline $26 / 03 / 20$ & Presos de SP vão confeccionar máscaras para proteção contra coronavírus \\
\hline $02 / 03 / 20$ & Preso faz 860 pontos na redação do Enem e sonha em cursar Direito \\
\hline $21 / 02 / 20$ & Presos pintam sete escolas na Região Noroeste \\
\hline $20 / 02 / 20$ & Sentenciados da PII de Hortolândia participam de curso de segurança no trabalho \\
\hline $20 / 02 / 20$ & O poder transformador da educação \\
\hline $18 / 02 / 20$ & Horta da Penitenciária II de Potim emprega reeducandos \\
\hline $14 / 02 / 20$ & Preso fatura medalha de bronze na Olimpíada de Matemática \\
\hline $12 / 02 / 20$ & Funcionários do CDP de Suzano são homenageados pela direção do presídio \\
\hline $12 / 02 / 20$ & Reeducandos participam de Curso de Auxiliar de Mecânica em Motores Diesel \\
\hline $03 / 02 / 20$ & Sebrae-SP transforma detentas em empreendedoras \\
\hline $03 / 02 / 20$ & Jornadas somam mais de 83 mil atendimentos a presos em 2019 \\
\hline $30 / 01 / 20$ & Maquiadores profissionais certificam reeducandos LGBTQI+ da Penitenciária José Parada Neto \\
\hline $30 / 01 / 20$ & Formaturas e Enem encerram ano letivo do sistema prisional da região central \\
\hline $27 / 01 / 20$ & Oficina de artesanato capacita detentas para o mercado de trabalho \\
\hline $15 / 01 / 20$ & Aliança entre SAP e Prefeitura de Praia Grande garante emprego a 200 detentos \\
\hline $08 / 01 / 20$ & Projeto marca 'gol' na ressocialização ao fazer presos recriarem estádios de futebol \\
\hline $08 / 01 / 20$ & Prefeitura de Jaboticabal firma contrato com a SAP para alocação de mão de obra carcerária \\
\hline $08 / 01 / 20$ & Expulso da escola aos 9 anos, preso é aluno destaque do $3^{\circ}$ ano do Ensino Médio \\
\hline $02 / 01 / 20$ & Penitenciária de Piracicaba realiza maior formatura da região central \\
\hline $02 / 01 / 20$ & Penitenciária II de São Vicente organiza mutirão de atendimento à população carcerária \\
\hline
\end{tabular}

Fonte: http://www.sap.sp.gov.br/noticias/noticias-trabalho-e-educacao.html

Infelizmente, esses projetos acabam sendo iniciativas isoladas, intermitentes, sem objetivos específicos gerais e específicos. SILVA (2006) coloca que há uma incompatibilidade entre os objetivos e metas da Educação e os objetivos e metas da pena e da prisão e que: 
Esta incompatibilidade não é de ordem epistemológica, ainda que se possa afirmar que a condição de confinamento prolongado, a necessidade de rápida adaptação a um ambiente hostil marcado pela cultura da violência e a perda de referenciais de valor seja capaz de suscitar outras formas de saberes e de produção de conhecimentos. A incompatibilidade também não é de ordem metodológica. A incompatibilidade, diria eu, é de ordem conceitual. Enquanto prevalecer a concepção de prisão como espaço de confinamento, de castigo, de humilhação e de estigmatização social, a Educação não terá lugar na terapia penal, limitandose a ser, como efetivamente é, apenas mais um recurso a serviço da administração penitenciária para ocupar o tempo ocioso de alguns poucos presos e evitar que se envolvam em confusões. A Educação é marcada pela intencionalidade e para isto se serve do espaço, do tempo, da progressividade dos conteúdos, do método, da didática, do controle e da avaliação e visa alcançar seus objetivos em médios e longos prazos (SILVA, 2006, p. 64).

O desenvolvimento dos objetivos educacionais exigem encaminhamentos e procedimentos que pretendam alcançar determinados resultados que são os pressupostos colocados para a reintegração, como habilidades para analisar, julgar e tomar decisões e, por sua vez, são determinantes da qualidade da interação social que o indivíduo estabelece, exatamente o que se pretende com a pena de privação da liberdade, ou seja, levar o indivíduo ao arrependimento, avaliar a consequência de seus atos e devotar respeito às demais pessoas.

a) Formação e capacitação para o trabalho:

A proposta desenvolvida aqui aponta diversas perspectivas de transformação de relações, entre indivíduos e organização do cárcere a partir da educação. Alfabetizar, adquirir escolarização básica, desenvolver habilidades e competências, desenvolver pilares que alicercem a reintegração, são alguns deles. Outro importante aspecto a ser tratado com acuidade no PPPprisões é minuciado por SILVA, MARQUES (2021), diz respeito a continuidade dos estudos com vistas à elevação, não apenas da escolaridade, mas também de suas competências técnicas relacionadas ao trabalho. Os artigos 35, 36 e 41 da LDB autorizam o atendimento desta demanda por meio do Ensino Médio, no qual também podem ser aproveitados os conhecimentos e habilidades anteriormente adquiridos, resultando em certificação de Educação Profissional de Nível Médio com validade nacional e em uma profissão, inclusive, àqueles que não concluíram o Ensino Médio e que, exercem no interior da prisão ofícios indexados na Classificação Brasileira de Ocupações (CBO). Os Artigos 39, 40, 41 e 42 da $\mathrm{LDB}^{67}$ autorizam diferentes articulações da Educação Profissional, inclusive com o próprio ambiente

67 LDB, 20/12/1996 Art. 39. A educação profissional e tecnológica, no cumprimento dos objetivos da educação nacional, integra-se aos diferentes níveis e modalidades de educação e às dimensões do trabalho, da ciência e da tecnologia. $\$ \mathbf{1}^{\mathbf{0}}$ Os cursos de educação profissional e tecnológica poderão ser organizados por eixos tecnológicos, possibilitando a construção de diferentes itinerários formativos, observadas as normas do respectivo sistema e nível de ensino. $\$ \mathbf{2}^{\mathbf{0}}$ A educação profissional e tecnológica abrangerá os seguintes cursos: I - de formação inicial e continuada ou qualificação profissional; II - de educação profissional técnica de nível médio; III - de educação profissional tecnológica de graduação e pós- 
de trabalho. Estas possibilidades estão regulamentadas no Catálogo Nacional de Cursos Técnicos e as Diretrizes Nacionais fazem menção à "preparação especial” (formação pedagógica) que devem receber os presos para atuação no apoio aos profissionais da Educação e a saúde.

Temos vasta publicação para oferta de curso técnico:

Parecer CNE/CEB nº 3/2012, aprovado em 26 de janeiro de 2012 - Atualização do Catálogo Nacional de Cursos Técnicos de Nível Médio. Parecer CNE/CEB nº 11/2012, aprovado em 9 de maio de 2012 - Diretrizes Curriculares Nacionais para a Educação Profissional Técnica de Nível Médio. Resolução CNE/CEB n 4, de 6 de junho de 2012 - Dispõe sobre alteração na Resolução CNE/CEB n 3/2008, definindo a nova versão do Catálogo Nacional de Cursos Técnicos de Nível Médio. Resolução CNE/CEB nº 6, de 20 de setembro de 2012 - Define Diretrizes Curriculares Nacionais para a Educação Profissional Técnica de Nível Médio. Parecer CNE/CEB no 2/2013, aprovado em 31 de janeiro de 2013 - Consulta sobre a possibilidade de aplicação de "terminalidade específica" nos cursos técnicos integrados ao Ensino Médio. Parecer CNE/CEB n 3/2013, aprovado em 20 de fevereiro de 2013 - Consulta sobre a autonomia de instituições privadas de Educação Superior para oferta de cursos técnicos de nível médio. Parecer CNE/CEB n ${ }^{\circ}$ 10/2013, aprovado em 2 de outubro de 2013 - Consulta sobre a obtenção de registro da habilitação profissional de Técnico em Farmácia, junto ao Conselho Regional de Farmácia do Estado de São Paulo, tendo em vista curso técnico concluído no ano de 2004. Parecer CNE/CEB no 2/2014, aprovado em $1^{\circ}$ de abril de 2014 - Solicitação de Parecer e Resolução para disciplinar a oferta de cursos técnicos de nível médio em caráter experimental, prorrogando prazo para sua implantação. Parecer CNE/CEB n ${ }^{\circ}$ 3/2014, aprovado em 4 de junho de 2014 - Classificação de cursos de Educação Profissional Técnica de Nível Médio. Parecer CNE/CEB nº 4/2014, aprovado em 5 de junho de 2014 - Consulta sobre o ensino técnico em contabilidade e sobre a profissão de Técnico em Contabilidade após o advento da Lei ${ }^{\circ}$ 12.249/2010. Parecer CNE/CEB n 7/2014, aprovado em 3 de setembro de 2014 - Reexame do Parecer CNE/CEB no 3/2014, que trata da classificação de cursos de Educação Profissional Técnica de Nível Médio. Parecer CNE/CEB n ${ }^{\circ}$ 8/2014, aprovado em 9 de outubro de 2014 - Atualização do Catálogo Nacional de Cursos Técnicos (CNCT) e reexame do Parecer CNE/CEB n ${ }^{\circ}$ 2/2014, contendo orientações quanto à oferta de cursos técnicos em caráter experimental. Parecer CNE/CEB

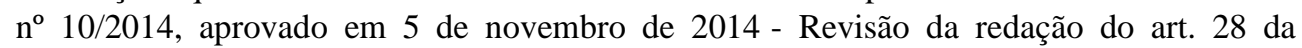
Resolução CNE/CEB no 6/2012, que define Diretrizes Curriculares Nacionais para a Educação Profissional Técnica de Nível Médio, à luz da redação do Parecer CNE/CEB n ${ }^{\circ}$ 11/2012. Resolução CNE/CEB no 1 , de 5 de dezembro de 2014 - Atualiza e define novos critérios para a composição do Catálogo Nacional de Cursos Técnicos, disciplinando e orientando os sistemas de ensino e as instituições públicas e privadas de Educação

graduação. $\$ \mathbf{3}^{\mathbf{0}}$ Os cursos de educação profissional tecnológica de graduação e pós-graduação organizar-se-ão, no que concerne a objetivos, características e duração, de acordo com as diretrizes curriculares nacionais estabelecidas pelo Conselho Nacional de Educação. Art. 40. A educação profissional será desenvolvida em articulação com o ensino regular ou por diferentes estratégias de educação continuada, em instituições especializadas ou no ambiente de trabalho. Art. 41. O conhecimento adquirido na educação profissional e tecnológica, inclusive no trabalho, poderá ser objeto de avaliação, reconhecimento e certificação para prosseguimento ou conclusão de estudos. Art. 42. As instituições de educação profissional e tecnológica, além dos seus cursos regulares, oferecerão cursos especiais, abertos à comunidade, condicionada a matrícula à capacidade de aproveitamento e não necessariamente ao nível de escolaridade. IN: http://www.planalto.gov.br/ccivil_03/leis/19394.htm 
Profissional e Tecnológica quanto à oferta de cursos técnicos de nível médio em caráter experimental, observando o disposto no art. 81 da Lei ${ }^{\circ}$ 9.394/96 (LDB) e nos termos do art. 19 da Resolução CNE/CEB no 6/2012. Parecer CNE/CEB no 6/2015, aprovado em 10 de junho de 2015 - Consulta sobre a possibilidade de realizar a matrícula e o cômputo da frequência de alunos de cursos técnicos subsequentes por disciplina. Parecer CNE/CEB n ${ }^{\circ}$ 7/2015, aprovado em 10 de junho de 2015 - Consulta referente à carga horária do curso técnico de Enfermagem oferecido pelo SENAC de Roraima. Parecer CNE/CEB no 11/2015, aprovado em 7 de outubro de 2015 - Consulta sobre Educação Profissional e aproveitamento de estudos. Parecer CNE/CEB n 2/2016, aprovado em 27 de janeiro de 2016 - Consulta sobre a composição da carga horária mínima para cursos de especialização de nível médio. Parecer CNE/CEB no 6/2016, aprovado em 5 de maio de 2016 - Consulta sobre a Resolução ${ }^{\circ}$ 16/2014 do Conselho Nacional de Radiologia (CONTER) e orientações sobre a aplicação de decisões judiciais para a matrícula de menores de 18 anos em cursos de Técnico em Radiologia. Parecer CNE/CEB n ${ }^{\circ} 7 / 2016$, aprovado em 8 de junho de 2016 - Consulta se as habilitações profissionais de nível médio, constantes do Catálogo Nacional de Cursos Técnicos (CNTC), são compatíveis com a atuação do egresso nos setores primário e secundário da economia e se enquadram no art. $9^{\circ}$ do Decreto $\mathrm{n}^{\circ} 90.922 / 85$, com a redação dada pelo Decreto $\mathrm{n}^{\circ} 4.560 / 2002$. Parecer CNE/CEB n ${ }^{\circ} 1 / 2017$, aprovado em 14 de fevereiro de 2017 - Solicitação de exclusão do curso de Técnico em Serviços Jurídicos do Catálogo Nacional de Cursos Técnicos (CNCT). Parecer CNE/CEB n ${ }^{\circ}$ 5/2017, aprovado em 9 de agosto de 2017 - Consulta acerca do controle de frequência em atividades não presenciais nos cursos técnicos de nível médio. Parecer CNE/CP no 13/2017, aprovado em 8 de agosto de 2017 - Recurso contra a decisão contida no Parecer CNE/CEB n ${ }^{\circ} 1$, de 14 de fevereiro de 2017, que indeferiu a solicitação de exclusão do Curso de Técnico em Serviços Jurídicos do Catálogo Nacional de Cursos Técnicos (CNCT). Parecer CNE/CEB n ${ }^{\circ}$ 6/2017, aprovado em 8 de novembro de 2017 - Consulta sobre formalidades nos certificados e diplomas emitidos por instituições de Educação Superior ofertantes de cursos pelo PRONATEC. Parecer CNE/CEB $n^{\circ} 1 / 2018$, aprovado em 24 de janeiro de 2018 - Consulta sobre estágio supervisionado na Educação Profissional. Parecer CNE/CP no 7/2020, aprovado em 19 de maio de 2020 - Diretrizes Curriculares Nacionais para a Educação Profissional e Tecnológica, a partir da Lei n ${ }^{\circ}$ 11.741/2008, que deu nova redação à Lei de Diretrizes e Bases da Educação Nacional (LDB). Parecer CNE/CP n ${ }^{\circ}$ 17/2020, aprovado em 10 de novembro de 2020 - Reanálise do Parecer CNE/CP n ${ }^{\circ}$, de 19 de maio de 2020, que tratou das Diretrizes Curriculares Nacionais para a Educação Profissional e Tecnológica, a partir da Lei $\mathrm{n}^{\circ}$ 11.741/2008, que deu nova redação à Lei de Diretrizes e Bases da Educação Nacional (LDB). Parecer CNE/CEB n ${ }^{\circ}$ 5/2020, aprovado em 12 de novembro de 2020 - Apreciação de Proposta apresentada pela SETEC/MEC para a $4^{\mathrm{a}}$ edição do Catálogo Nacional de Cursos Técnicos (CNCT).Resolução CNE/CEB n 2 2, de 15 de dezembro de 2020 - Aprova a quarta edição do Catálogo Nacional de Cursos Técnicos. Resolução CNE/CP no 1 , de 5 de janeiro de 2021 - Define as Diretrizes Curriculares Nacionais Gerais para a Educação Profissional e Tecnológica.

Essas publicações, de normativas para cursos técnicos referendam a afirmação de que temos no Brasil publicação de Diretrizes, resoluções e pareceres, para múltiplas ofertas educacionais. SILVA, MOREIRA apontaram sobre o modelo de implementação de projeto em unidade prisional, a partir da legislação: 
Os presos que possuem o Ensino Médio Completo podem se beneficiar da Educação Profissional, estes sim, no sentido de aprendizagem de uma profissão de nível técnico, como são os casos dos monitores de Educação ( $\$ 2^{\circ}$ do Artigo $9^{\circ}$ das Diretrizes) e do Agente Prisional de Saúde (Art. $9^{\circ}$ da Portaria Interministerial 1777, de 9.9.2003 que institucionaliza o Plano Nacional de Saúde no Sistema Penitenciário). Este Plano prevê a qualificação profissional de pelo menos 5\% dos presos como Agentes Prisionais de Saúde, com formação equivalente ao do Agente Comunitário de Saúde. SILVA, MOREIRA, 2006, p. 8)

Enfatizo dois pontos cruciais para a reorganização do território prisional:

(1) A Educação reconhece a cada um seus direitos, proporcionalmente aos seus esforços, empenho e rendimento e não há quem não se felicite a si próprio por ter vencido etapas na sua trajetória educacional. O baixo nível de escolaridade e a baixa qualificação profissional da população prisional no Brasil é uma das razões da exploração da mão de obra do preso, com remuneração vergonhosa, sem direitos previdenciários e trabalhistas e em qualquer possibilidade de aproveitamento deste trabalho quando em liberdade. A Educação é fundamental para a qualificação desta mão de obra seja na tarefa da alfabetização, da elevação da escolaridade ou da profissionalização propriamente dita e é desejável que o preso esteja cursando o Ensino Médio, pelo menos, para que a profissionalização seja efetiva e possa representar a aquisição de uma profissão que possa ser exercida quando em liberdade. (SILVA, MARQUES, 2021, p. 58).

(2) A função real da teoria científica é penetrar a superfície empírica da realidade e captar as relações que geram as formas aparentes ou estritamente sensíveis. Por isso, os conceitos teóricos da ciência não são redutíveis a conceitos observáveis. Eles procuram descrever os aspectos não observáveis da realidade, que se manifestam de forma contraditória (Kosik, 1976). Ainda, de acordo com Roberto da Silva (2010), a ausência de cientificidade no trabalho dentro da prisão tem dado margem ao espontaneísmo, ao empirismo e à experimentação de uma variedade de projetos pontuais, propostos ou vendidos por indivíduos, grupos e entidades, que nem sempre se coadunam com a legislação específica ou com uma filosofia de trabalho. Em geral, na produção do conhecimento reconhecido como científico, nas ciências humanas e sociais, entre as quais a educação, aceita-se que a explicitação do método e o rigor na sua aplicação conferem ao conhecimento obtido a qualidade de científico ou de verdadeiro. O próprio alargamento das fronteiras da ciência e das novas formas de o ser humano se relacionar com o mundo, inclusive as formas destrutivas que têm ameaçado a sobrevivência do gênero humano, as políticas ditatoriais, os enriquecimentos ilícitos à custa do empobrecimento de milhões, tem trazido à tona a complexidade do conhecimento dito verdadeiro e 
os múltiplos saberes de que é portadora a humanidade na sua história milenar e, em grande parte, desconhecida. Um conceito correlato a essa discussão, hoje, é o de desenvolvimento que de um lado é apresentado como a oportunidade de geração de trabalho e renda, e de outro deixa evidente a existência do desenvolvimento econômico em detrimento do desenvolvimento social, do bem-estar da vida nos seus aspectos fundamentais (moradia, saúde, educação etc.).

b) Remição da pena pelo desenvolvimento/participação de projetos educacionais

A primeira experiência de criar uma legislação própria para remir parte da pena de prisão por meio da educação em prisões na América Latina ocorreu no ano de 1971, no México. Ela foi inspirada por uma iniciativa espanhola, que permitiu reduzir o tempo de prisão por meio do trabalho de pessoas presas, em 1937. O Peru foi o segundo país a regulamentar a remição de pena pela educação dentre os países latinos, por meio do Decreto Lei nº 23.164, em 1980, seguido da Venezuela e da Bolívia.

A remição de pena pelo estudo foi pauta recorrente no Congresso Nacional Brasileiro tramitou pela primeira vez em 1993 e foram encaminhados outros 27 Projetos de Lei ao longo de 18 anos. O Brasil foi o décimo e último país da América Latina a institucionalizar a remição de pena pelo estudo com a promulgação da Lei ${ }^{\circ}$. 12.433, de 29 de junho de 2011, de autoria do senador da república Cristovam Buarque. A legislação trouxe alterações especificamente à Lei de Execução Penal, a fim de incluir entre as diretrizes do tratamento penal brasileiro a garantia do direito do preso, reduzir parte do tempo de pena estudando em prisões e estabeleceu a contagem de tempo específica de 12 horas de estudo para cada dia remido. ${ }^{68}$

\footnotetext{
68 Art. 126. O condenado que cumpre a pena em regime fechado ou semiaberto poderá remir, por trabalho ou por estudo, parte do tempo de execução da pena. § 10 A contagem de tempo referida no caput será feita à razão de: I - 1 (um) dia de pena a cada 12 (doze) horas de frequência escolar - atividade de ensino fundamental, médio, inclusive profissionalizante, ou superior, ou ainda de requalificação profissional - divididas, no mínimo, em 3 (três) dias; II - 1 (um) dia de pena a cada 3 (três) dias de trabalho. § 20 As atividades de estudo a que se refere o § 1o deste artigo poderão ser desenvolvidas de forma presencial ou por metodologia de ensino a distância e deverão ser certificadas pelas autoridades educacionais competentes dos cursos frequentados Também assegura ao apenado o direito de beneficiar-se da acumulação simultânea, ou seja, passa a vigorar a garantia de "remir dobrado", ou seja, acumular a redução de um dia pelo estudo e outro dia pelo trabalho, desde que ocorra a compatibilidade de horários nas atividades. Assim, o parágrafo 30 dispõe que "Para fins de cumulação dos casos de remição, 87 as horas diárias de trabalho e de estudo serão definidas de forma a se compatibilizarem". A legislação entende que a remição deve ser mantida ao indivíduo preso que estude e/ou trabalhe e encontrar-se impedido de frequentar a atividade, determinando no "§ 4o O preso impossibilitado, por acidente, de prosseguir no trabalho ou nos estudos continuará a beneficiar-se com a remição" (BRASIL, 2011).
} 
Ainda que haja o avanço como garantia de remição da pena pela educação, nos deparamos com algumas questões:

- Apesar da remição ser "pela educação", na falta de centros que avaliem e encaminhem avaliação e validação das ações de educação desenvolvidas nas Unidade Prisionais, mais uma vez os encaminhamentos pertinentes a educação estão disciplinados e submetidos ao jurídico;

- Como não há oferecimento de educação escolar para todos, e os critérios para acessar as classes escolares não são claros, a remição pela educação, pode se tornar mais um elemento de desigualdade de acesso às assistências.

É fundamental o amadurecimento da cultura da remição e caminhando junto com o PPPprisões, devendo a mesma ser normatizada em parceria entre a educação e execução, mas acompanhada e avaliada nos centros educacionais e depois encaminhadas para providencias cabíveis. Atualmente quem encaminha oferta, fiscalização e avaliação da Educação em prisões são as instituições auxiliares da Justiça (Art. 61 da LEP), especialmente Conselho Penitenciário, Patronato e Conselho da Comunidade, cujas atribuições são necessárias e desejáveis na elaboração, fiscalização e avaliação de um projeto político educacional no cárcere. SILVA, MOREIRA (2006) sinalizaram quanto a modelos de organização para remir pena de prisão:

[...] que obedecendo-se estritamente ao que dispõe a legislação brasileira quanto à carga horária, dias de efetivo trabalho escolar e as diretrizes curriculares para as diversas modalidades de ensino, entendemos ser possível conciliar a remição da pena pela Educação com os requisitos necessários para integralização de estudos. Dentro da mesma lógica, mas computando-se a data inicial do edital de lançamento até a data de realização das últimas provas, atividades de estudo que não são curriculares nem formais, mas que representam importantes passos na construção de uma biografia escolar e profissional, tal como aprovação em vestibular e aprovação em concurso público pode obter a mesma equivalência. Assim, considerando-se o tempo estimado em lei para a conclusão de cada nível ou modalidade de ensino concluída, justificar-se-ia o desconto proporcional na pena, que em média representa o abatimento de um terço da pena, conforme demonstração abaixo: Modelos de EJA- Ens. Fundamental ( $1^{\mathrm{a}}$ a $4^{\mathrm{a}}$ séries), deve ser concluído em 500 dias $(2.000 \mathrm{~h} / \mathrm{a})$, justificando o abatimento de $1 / 3$ da pena, ou seja, 166 dias.- Ens. Fundamental ( $5^{\mathrm{a}}$ a $8^{\mathrm{a}}$ séries), deve ser concluído em 400 dias (1.600 h/a), justificando o abatimento de 1/3 da pena, ou seja, 133 dias. Ensino Médio deve ser concluído em 600 dias (2.400 h/a), justificando o abatimento de $1 / 3$ da pena, ou seja, 200 dias. Curso superior de 2 anos pode ser concluído em 400 dias ( $1.600 \mathrm{~h} / \mathrm{a})$, justificando o abatimento de 1/3 da pena, ou seja, 200 dias. Curso Superior de 3 anos pode ser concluído em 600 dias $(2.400 \mathrm{~h} / \mathrm{a})$, justificando o abatimento de 1/3 da pena, ou seja, 200 dias. Curso Superior de 4 anos pode ser concluído em 800 dias (3.200 h/a), justificando o abatimento de 1/3 da pena, ou seja, 266 dias. Curso Superior de 5 anos ou mais podem ser concluídos em, no mínimo 1.000 dias letivos $(4.000 \mathrm{~h} / \mathrm{a})$, justificando o abatimento de $1 / 3$ da pena, ou seja, 333 dias. Conforme se depreende, esta forma de cálculo pode ser aplicada a todos os níveis e modalidades de ensino, proporcionando sempre a redução de 1/3 na pena, o que é aplicável também nas demais modalidades: Pós-graduação (Especialização), 
em 180 dias; Pós-graduação (mestrado acadêmico), em 720 dias; Pós-graduação (mestrado profissionalizante), em 1.095 dias; Pós-graduação Stricto Sensu (doutorado), em 1.460 dias; Curso Profissionalizante, em 120 dias ou (480 h/a); Curso de Aperfeiçoamento, em 90 dias ou 360 h/a; Curso de Atualização, em 30 dias ou 120 h/a. (SILVA, MOREIRA, 2006, p. 04)

No que tange a remição, já apresentei anteriormente a Resolução 391 de 10/05/2021, que trouxe importantes pontos para referendar as proposições de efetivação e avanço das ações educativas nos territórios prisionais, a partir do PPPprisões.

\section{Algumas recomendações para o PPPprisões}

Há no país atualmente, contemplados diversos pareceres de desenvolvimento e reconhecimento legal de formação e modelos de educação, considerando experiências pedagógicas para oferta prioritária de educação a diversos grupos, considerando reconhecimento de saberes, conhecimento e experiências pedagógicas, situações desenvolvidas em estudos anteriores, na vida e no próprio ambiente de trabalho, projetos de avaliação, para fins de continuidade de estudos e certificação. Ressalto que há a necessidade de aprofundamento deste item em um próximo trabalho. Entretanto, acrescento algumas observações a serem consideradas para possível regulamentação do PPPprisões como experiência educacional de educação nas unidades prisionais, amparado, principalmente, no art. 81 da LDB. Assim, para a regularização dos projetos desenvolvidos no território apresento alguns pontos:

- Implantação e desenvolvimento de projetos/cursos para a EJA em regime de experiência pedagógica, nos termos do art. 81 da LDB.

- Pleitear junto ao CNE aprovação da implantação e funcionamento de projetos/cursos desenvolvidos no território prisional, com abrangência nacional, em regime de experiência pedagógica, nos termos do art. 81 da LDB, contando com a adesão e cooperação das Secretárias de Educação e de Execução Penal;

- Disciplinar ações e projetos, por meio de acompanhamento e avaliação de experiência pedagógica com base nas diretrizes para a política de EJA e da educação em regime de privação de liberdade;

- Criar centros pedagógicos nos territórios prisionais que, entre outras ações, elaborará metodologia de monitoramento e avaliação dos Projetos, com proposição de melhorias, inclusive em regime de experiência pedagógica;

○ Formação intensiva, discussão e formulação de ações de aperfeiçoamento do processo. 
- Criar mecanismos para pensar a estrutura curricular que contempla o reconhecimento, validação e certificação de saberes inerentes e construídos na vivência do território prisional;

○ Considerar a integração da EJA com a Educação Profissional e parcerias om instituições de educação de cursos técnicos e superiores;

○ O PPPprisões ter como foco amplo de atendimento o resgate da biografia e da história de vida do educando, reconhecendo sua identidade de sujeito e cidadão atuante na sociedade.

- Respeito às peculiaridades de cada educando, considerando suas características, interesses e condições de vida e trabalho.

- Elevação do nível de escolaridade com foco no mundo do trabalho, desenvolvimento de habilidades e competências de forma contextualizada, considerando as necessidades da vida e respeitando-se os perfis da população, reconhecimento de saberes e situações de educação, com vistas, inclusive a reintegração social;

○ Reconhecimento e valorização da diversidade humana e cultural;

- Reconhecimento do direito e da capacidade do sujeito de aprender, de evoluir e de se desenvolver, de mudar os modos de viver e transformar o mundo, ao longo de toda a vida.

○ Concepção do ato pedagógico como ato de conhecimento e ato político, realizado em processo dialógico entre todas as assistências e seus atores;

○ Reconhecimento, validação e certificação dos saberes adquiridos pelos sujeitos em todos os processos de educação e nas experiências de vida e trabalho;

- Flexibilização dos percursos de formação de modo a conciliar o aproveitamento dos saberes da experiência e vivências dos atores e o tempo do educando entre trabalho, família, estudo e lazer;

○ Contextualização do processo de aprendizagem valorizando atividades e vivências socializadoras, culturais, recreativas, esportivas;

○ Produção de materiais didático-pedagógicos contextualizados e adequados;

○ Basilares itens que deverão ser apresentadas em todos os PPPprisões nos seguintes aspectos:

$\checkmark$ Concepção de projetos com estratégias de oferta flexíveis.

$\checkmark$ Carga horária proporcional às situações e habilidades reconhecidas, validadas e certificadas no processo de reconhecimento de saberes. 
Conclusão do curso/projetos e certificação a qualquer tempo, uma vez atendidos os requisitos da matriz e carga horária ${ }^{69}$;

- Desenvolver os projetos a partir de módulos, observando flexibilização curricular, reconhecimento das competências desenvolvidas pelo educando ao longo da vida a partir de um processo organizado pedagogicamente, dentro da Matriz de Referência Curricular, ${ }^{70}$ podendo ocorrer por área de conhecimento e abranger diferentes processos e métodos, com registro rigoroso feitos em relatórios;

○ Nos projetos observar adaptação do currículo aos diferentes perfis e à diversidade de grupos de cada território prisional;

- Integração e contextualização dos saberes nas dimensões científica, cultural e técnica, mobilizando as competências na resolução dos problemas e dando significado ao conhecimento;

- Acolhimento e diagnóstico do processo de reconhecimento de saberes, onde serão definidos os perfis e itinerários;

- Definir objetivos a alcançar pelos envolvidos, estabelecendo temas de estudos, projetos de pesquisa e de vida;

○ Avaliação da Aprendizagem de caráter diagnóstico

- Validar certificação e remição pelo estudo, a partir do acompanhamento, monitoramento e avaliação.

Esse trabalho apresenta o Projeto Político Educacional para as prisões, desenvolvendo proposições possíveis para sua implementação e colocando o campo de disputa que se encontra o PPPprisões, apontando que é sob a perspectiva de mobilização da academia, dos trabalhadores da área, de sujeitos do território prisional que conseguiremos avançar na garantia de direitos da população carceraria.

\footnotetext{
69 Exemplos de divisão desse tempo, de acordo com o projeto proposto no PPPprisões pela Unidade Prisional: \% em sala de aula, podendo ser espaços descentralizados; \% no ambiente de trabalho/ atuação; \% em atividades contextualizadas por ramo de atividade/assistência; \% de orientação de estudo; \% de atividades individuais orientadas a distância; \% em Plataforma (ambiente virtual de aprendizagem); \% com atividades contextualizadas no ambiente de trabalho por ramo de atividade. Todas, necessariamente sob a supervisão e responsabilidade do centro educacional

70 Fundamentando-se na Base Nacional Comum Curricular (BNCC) é um documento de caráter normativo que define o conjunto orgânico e progressivo de aprendizagens essenciais que todos os alunos devem desenvolver ao longo das etapas e modalidades da Educação Básica.
} 
Por fim, aponto que do ponto de vista arquitetônico e disciplinar, é necessário que os envolvidos com a educação prisional tenham como princípio e preocupação a ocupação do território, instituindo novas perspectivas em relação ao espaço e ao tempo, suprimindo encaminhamentos, como confinamentos, isolamento, alienação, que não colaboram com o objetivo primordial do modelo aqui proposto: o estudo, a reflexão crítica, o debate de ideias e a problematização da condição existencial do preso e sua reintegração. 


\section{CONSIDERAÇÕES FINAIS}

Cumpre salientar que no âmbito do direito constitucional moderno, as pessoas que praticam crimes, investigadas, processadas ou já condenadas têm o direito fundamental de ver respeitada a sua dignidade. Kant (2002) ensina que, "um princípio reconhecido como verdadeiro jamais deve ser abandonado, independentemente do perigo aparente que nele encontre, pois o que se deve compreender aqui não é o perigo de causar dano, mas, em termos gerais, de cometer uma injustiça" (KANT, 2002, p. 124), ou seja, ao desrespeitarmos a dignidade da pessoa humana, ainda que particularmente em relação aos considerados criminosos, não podemos nos desresponsabilizar de que essas pessoas sejam tratadas com dignidade. Ao contrário do disposto acima, quando se trata de segurança pública, encontramos ineficácia e depreciação e ainda temos a mesma estrutura e modelo de séculos atrás, mesmo que a Constituição Federal de 1988 tenha avançado na garantia de direitos e mesmo o Brasil sendo signatário de tratados e convenções que tratam do tema. Claudio Amaral, afirma que é necessário "repensar a utilização da pena privativa de liberdade enquanto uma das principais formas de exteriorização do direito penal, visto que não são asseguradas a integridade física e moral dos detentos e o correto cumprimento da pena. Uma situação absurda e intolerável” (AMARAL, 2008, p. 29-41) ${ }^{45}$.

Temos vivenciados que as garantias dos Direitos Humanos, diante da crise econômica mundial, especialmente no Brasil, fragilizaram a efetivação delas, tornando um grande desafio a manutenção de direitos já conquistados e a permanência do estado democrático de direito. Conti (2018) esclarece essa fragilidade:

[...] a situação do sistema carcerário, se reconhece que a situação carcerária é uma das questões mais complexas da realidade social brasileira. Estando o encarcerado sob a custódia do Estado, este se torna integralmente responsável por fazer valer os respectivos direitos fundamentais previstos na Constituição. Convém não esquecer que resolver esse problema não é somente essencial para manter a dignidade daqueles que estão presos, mas também uma forma de permitir que a pena seja efetivamente um instrumento de ressocialização e consequente pacificação social, em benefício de toda a sociedade. (CONTI, 2018, pp. 75-80). ${ }^{46}$ 
Para que a mudança preconizada nos documentos ocorra, o princípio vertebral a sustentar todos os demais deve ser o princípio de proteção integral de direitos humanos, erigido como o objeto e limite do poder de punir e no qual o direito à segurança da pessoa, da vida e dos corpos, antes que dos bens seja um deles. (ANDRADE, 2013 p. 29-41).

Apesar da sensação de que os direitos sociais, tais como os de igualdade, moradia, alimentação, saúde e educação, uma vez que estão institucionalizados e que existe instrumentos de garantias desses direitos, através de leis, tratados e declarações, estejam implantados, temos inúmeras situações concretas onde na prática, cotidianamente podemos ver inúmeras demonstrações de que eles não se concretizam.

No que diz respeito ao direito à educação, proteção e demandas de direitos, saliento que a educação escolar pública, gratuita e de qualidade a todas as pessoas, inclui ainda, a oferta da Educação Básica aos jovens e adultos. Garantir o acesso a todos e a permanência à política pública de Educação Básica, perpassa também pelo respeito às diferenças, à dignidade humana e na igualdade de oportunidades. Para isso, é necessário também ampliar essas formas de oferta e acesso, considerando os territórios e a população a ser atendida. Para atender a públicos tão diversos como o brasileiro por exemplo, necessariamente, precisamos pensar em projetos educacionais para a educação escolar, projetos inclusivos e que atendam as especificidades, incluindo-se necessariamente, as pessoas em situação de privação de liberdade

Contextualizar a educação e os sujeitos da EJA prisional, investigar e traçar caminhos a partir da demanda de uma política pública que responsabiliza ao Estado também a educação de pessoas privadas de liberdade é uma pauta que contribui para reiterar e avançar no desenvolvimento de garantias de direitos sociais.

Esse trabalho destacou a importância da academia e grupos de pesquisa nas proposições de políticas públicas. No que tange a garantia de direitos destaquei também a importância de movimentos sociais e sociedade civil para avanços e consolidação de políticas públicas em educação e especificamente educação aos privados de liberdade.

Aponto, como Supervisora de Ensino, que houve a possibilidade de desenvolver o acompanhamento de políticas de educação e de educação prisional desde 2010, na Diretoria de Ensino. A elaboração e implementação do Programa de Educação em prisões ainda encontra 
resistência, receios, preocupações, pois atualmente temos duas instituições, a Secretaria de Administração Penitenciaria e a Secretaria Estadual de Educação, em campos absolutamente opostos de interesses atuando no território prisional. Ainda, a educação desenvolvida nos territórios prisionais atende a uma parcela mínima da população encarcerada, além disso, como já dito, em uma conjuntura onde os direitos mínimos não são garantidos, em que o preconceito é imenso e incentivado pelo governo federal, em que se referenda o punitivismo em detrimento da reintegração social, em que diversas concepções estereotipadas que trazem ideias de desperdício de custos das ações, duvidam de resultados, desestimulam quaisquer projetos de reintegração social.

Apesar de termos legislações, normas e diversas práticas voltadas para a formação das pessoas em privação de liberdade, as prisões brasileiras são espaços organizados a partir de saberes assimilados da segurança pública, fazendo com que prevaleçam práticas punitivas, em detrimento da preparação dos sujeitos para o retorno à liberdade. É imprescindível que o Estado encaminhe programas consistentes de educação no cárcere, reconhecendo as especificidades inerentes aos territórios prisionais e que sejam programas permanentes, pensado a longo prazo, para assim, responder às expectativas legais, com demonstração de resultados positivos e consequente mudança de cultura.

Validar e avançar nas proposições que envolvam questões ligadas aos direitos das minorias, pesquisar os impactos e possíveis avanços no ensino aprendizagem e na reintegração social a partir da proposta de gestão do projeto político pedagógico em prisões, num momento em que às populações pobres sofrem ataques repetitivos à direitos, sofrem retrocessos constitucionais e se acentua a crise social, é um grande desafio. Esta dissertação desenvolveu a proposta de Projeto Político Pedagógico das prisões apontando caminhos para mudanças de paradigmas na organização do território prisional e na oferta de educação nestes espaços, reconhecendo a necessária mudança para que haja efetivamente o desenvolvimento de ações educacionais em um contexto em que, para além das especificidades de desenvolvimento de aulas tradicionais em um espaço com características próprias, haja o necessário entendimento de que a educação é a mola propulsora e constituidora de novos paradigmas para a educação prisional.

A proposta de PPPprisões aqui apresentada se fundamenta nos dispositivos da Constituição Federal de 1988, que determina que, cada uma das escolas, desenvolva autonomia para delinear um modelo de trabalho com identidade, de acordo com as suas necessidades e que se torne referencial 
para todas as instituições escolares. A Lei de Diretrizes e Bases da Educação 9394/96 (LDB), prevê no TÍTULO IV, Organização da Educação Nacional, em seus artigos 12, 13 e $14^{71}$ a incumbência da elaboração da proposta pedagógica das escolas. A expressão proposta pedagógica apareceu pela primeira vez na história da legislação de ensino na Lei 9.394/96, no inciso I do Artigo 12: “Os estabelecimentos de ensino, respeitadas as normas comuns e as do seu sistema de ensino, terão a incumbência de: I- elaborar e executar sua proposta pedagógica", colocando em destaque esse princípio.

Pensando na garantia de direitos e de avanços para a população carceraria com a perspectiva de mudanças a partir da educação, é fundamental o fomento a uma cultura educacional nos espaços de privação de liberdade, que envolva todas as assistências da execução penal e todos os funcionários participantes dela, desenvolvendo projetos/ações que estejam ligadas a formação, compreendendo a especificidade desse contexto com foco na promoção da cidadania e na reinserção à sociedade das pessoas em situação de privação de liberdade.

A mudança cultural proposta perpassa pelo reconhecimento do protagonismo e de direitos das pessoas privadas de liberdade, e ainda, apresenta novas referências para a organização administrativa das unidades prisionais, para um novo modelo de articulação entre as secretarias, com reestruturação das ações a serem desenvolvidas pelos servidores penitenciários e da área pedagógica, o que exige a participação dos diversos atores, entre eles, os Conselhos penitenciários e representantes das secretarias estaduais de educação. No caso de SP, temos as Diretorias Regionais de Ensino, que contam com os Supervisores de Ensino.

É necessário reafirmar que a educação é um direito inalienável que deve ser garantido a todos e é imprescindível que seja acessível, transformadora e cada vez mais distante da seletividade e da exclusão. Aportou-se neste trabalho uma concepção de educação abrangente a todas as assistências nos espaços prisionais, desencadeada a partir da pesquisa participativa e por uma conjunção de publicações legislativas, tanto em âmbito da educação como na execução penal. Assim esta

\footnotetext{
${ }^{71}$ Art. 12. Os estabelecimentos de ensino, respeitadas as normas comuns e as do seu sistema de ensino, terão a incumbência de: I - elaborar e executar sua proposta pedagógica; (...) Art. 13. Os docentes incumbir-se-ão de: I - participar da elaboração da proposta pedagógica do estabelecimento de ensino; II - elaborar e cumprir plano de trabalho, segundo a proposta pedagógica do estabelecimento de ensino; Art. 14. Os sistemas de ensino definirão as normas da gestão democrática do ensino público na educação básica, de acordo com as suas peculiaridades e conforme os seguintes princípios: I - participação dos profissionais da educação na elaboração do projeto pedagógico da escola; II - participação das comunidades escolar e local em conselhos escolares ou equivalentes.
} 
pesquisadora e o GEPEPRIVACAO debruçou-se em pesquisas e caminhos para projetos políticos pedagógicos nos espaços de privação de liberdade que busquem garantir a equidade, que reconheçam a pluralidade, as diferenças de ritmos de aprendizagem e de cultura, que reconheçam diferentes dimensões de formação e que contribuam para interromper ciclos de repetição de exclusão histórico no Brasil. Freire (1999, p. 36) bem coloca que a construção de um projeto político transformador está voltada para a autonomia do educando, valorizando e respeitando a sua cultura, o seu acervo de conhecimentos e sua individualidade.

A formulação de um Projeto Político Pedagógico das prisões coloca novas perspectivas aos processos de gestão vigentes hoje e tem o desafio de transformar, conceber e implantar um novo modelo de organização, que através da educação privilegie o desenvolvimento das pessoas privadas de liberdade, buscando contribuir também para interromper com o processo crescente de encarceramento, com os ciclos individuais e coletivos de prisão, soltura, novo aprisionamento. Assim o PPPprisões coloca às diferentes instituições a perspectiva de articulação interinstitucional entre as secretarias de Estado e se coloca como um instrumento educacional de ressignificação do sentido historicamente atribuído à pena de prisão ao propor que a educação se torne o principal constituinte para cumprimento do objeto de reintegração social. Trata-se aqui de uma tarefa complexa e desafiadora, que exige gerar pertencimento, esforço, cooperação, planejamento e, necessariamente, regulamentação de normas.

O tempo no território prisional deve ser otimizado, encarado como oportunidade de uma socialização/vivência o mais plena possível dos sujeitos, ultrapassando os limites curriculares ao desenvolver projetos interdisciplinares que reconheçam a vivência dos envolvidos. Cumpre buscar o caminho da inclusão e reinserção na sociedade, estimulando novas trajetórias e promovendo fatores de proteção social, colocando a educação como alternativa de redução de impactos da vulnerabilidade social e de redução da pena, demonstrando realmente ser fomento para reintegração social dos apenados.

Ainda, como alerta de André (1993, p. 17) "é preciso romper com uma visão de cotidiano escolar estático, repetitivo, disforme, homogêneo". Acrescento que é preciso romper com modelos historicamente postulados para efetivamente atender as especificidades, olhar o educando, colocar a educação como agente das transformações necessárias para garantir equidade, inclusão, igualdade. 
O PPP é um instrumento que possibilita esse atendimento específico, modular, focado nas práticas escolares e no contexto em que estão inseridos os sujeitos participes da educação preconizada. Azanha (1998) esclarece que

\begin{abstract}
Num projeto pedagógico tudo é relevante na teia das relações escolares, porque todas elas são potencialmente educativas ou deseducativas. Ensinar bem, por exemplo, não é apenas ensinar eficientemente uma disciplina, mas é também o êxito em integrar esse ensino aos ideais educativos da escola. Enfim, o importante é a motivação e o empenho comum numa reflexão institucionalmente abrangente e o firme propósito de alterar práticas e para isso, não há fórmulas prontas e convém não esperar auxílio de uma inexistente 'ciência dos projetos' ou de roteiros burocratizados. Elaborar o projeto pedagógico é um exercício de autonomia. (AZANHA, 1998, p. 15).
\end{abstract}

Operar a partir do PPPprisões contextualizando a educação e os sujeitos da EJA prisional, os impactos e possíveis avanços no ensino aprendizagem e reinserção social, num momento em que as populações pobres sofrem ataques repetitivos aos direitos, sofrem retrocessos constitucionais e se acentua a crise social, é imprescindível. Investigar e traçar caminhos a partir da demanda de uma política pública que responsabiliza o Estado pela educação de pessoas privadas de liberdade, é uma pauta que contribui para reiterar e avançar no desenvolvimento na busca de um projeto de educação prisional, que vai ao encontro das ideias de Arroyo (2010),

[...] todo projeto educativo tem que ser um projeto de humanização, isto implica reconhecer a desumanização, ainda que seja uma dolorosa constatação. Juntar cacos de humanidade de tantos milhões de brasileiros triturados pela injustiça, fome, provocadas pela brutalidade do capitalismo. Buscar a viabilização da humanização no contexto real, concreto, do Brasil. Este é o desafio pedagógico do Projeto Popular: Recuperar a Humanidade roubada do povo (ARROYO, 2010, p. 247).

Todo projeto educativo tem que ser um projeto de humanização. No contexto da educação prisional, o conceito norteador de todas as ações é o da humanidade, com a meta de promover a reintegração social. Trata-se de garantir um direito humano inalienável. Pensar educação no cárcere significa buscar necessariamente, confrontar e transformar diversas questões que agonizam as prisões desse país, algumas já citadas nesta dissertação. 
O PPPprisões objetiva não apenas novas ações, apresenta mudança de paradigmas e de organização do território prisional. Foi proposto neste trabalho que o fio condutor no caminho de transformação da cultura prisional seja a educação. 


\section{REFERÊNCIAS BIBLIOGRÁFICAS}

ABREU, Sérgio França Adorno de. A gestão urbana do medo e da insegurança: violência, crime e justiça penal na sociedade brasileira contemporânea. 1996. 282 f. Tese (apresentada como exigência parcial para o Concurso de Livre-Docência em Ciências Humanas) - Departamento de Sociologia, da Faculdade de Filosofia, Letras e Ciências Humanas da Universidade de São Paulo, São Paulo, 1996.

AMARAL, Cláudio do Prado. Uma decisão judicial emblemática sobre o problema da superpopulação carcerária: o comprometimento da pena pela aniquilação do sistema de justiça penal no processo de execução. Revista Ultima Ratio, Rio de Janeiro, ano 2, n. 2, Lumen Iuris, pp. 29-41, 2008.

ANDRADE, Vera Regina Pereira de. A mudança do paradigma repressivo em Segurança Pública: reflexões criminológicas críticas em torno da proposta da $1^{\mathrm{a}}$ Conferência Nacional Brasileira de Segurança Pública. Revista Seqüência (Florianópolis), n. 67, pp. 335 - 356, 2013.

ARROYO, Miguel. Paulo Freire e o projeto popular para o Brasil. In: SOUZA, Ana Inês. Paulo Freire - Vida e Obra. Expressão Popular, 2 ed. São Paulo, 2010.

ASSIS, Rafael Damasceno de. As prisões e o direito penitenciário no Brasil. Disponível em:< http://www.direitonet.com.br/artigos/exibir/3482/Asprisoes-e-odireito-penitenciário-no-Brasil> . Acesso em: 12 de junho de 2013.

AZANHA, José Mario Pires. Proposta pedagógica e autonomia da escola. Caderno de História e Filosofia da educação, V II, n 4, São Paulo, 1998.

BARATTA, Alessandro. Ressocialização ou controle social: uma abordagem crítica da “reintegração social” do sentenciado. Universidade de Saarland, R.F.A, Alemanha Federal, 2006. Disponível em: <http://www.juareztavares.com/textos/baratta_ressocializacao.pdf.> Acesso em: $23 / 08 / 2020$. 
BECCARIA, Cesare. Dos Delitos e das Penas. São Paulo: Ed. Ridendo Castigat Mores. Versão para eBook, 2013.

BENELLI, Silvio José. Foucault e a prisão como modelo institucional da sociedade disciplinar. In: A lógica da internação: instituições totais e disciplinares (des)educativas [online]. São Paulo: Editora UNESP, 2014, pp. 63-84. ISBN 978-85-68334-44-7. Available from SciELO Books, 2014.

BENEVIDES, Maria Victoria. Direitos humanos: desafios para o século XXI. In: SILVEIRA, Rosa Maria Godoy, et al. Educação em direitos humanos: fundamentos teórico-metodológicos. João Pessoa: Ed. Universitária, 2007.

BITTAR, Carla Bianca. Educação e direitos humanos no Brasil. São Paulo: Atlas, 2014.

BOTO, Carlota. A escola do homem novo: entre o iluminismo e a revolução francesa. São Paulo: UNESP, 1996.

BRAGA, Ana Gabriella Mendes. As funções da prisão no contexto contemporâneo. In: Revista Brasileira de Ciências Criminais. Vol 107. Mar/abril 2014. São Paulo: Revista dos Tribunais, 2014.

BRASIL. Lei N. 7.210, de 11 de julho de 1984. Institui a Lei de Execução Penal. Disponível em: <http://www.planalto.gov.br/ccivil_03/LEIS/L7210.htm>. Acesso em 20/06/2019. Acesso em $10 / 08 / 2020$

. Ministério da Justiça. Departamento Penitenciário Nacional. Levantamento Nacional de Informações Penitenciárias INFOPEN. Disponível em BRASIL. Lei no 7.210, de 11 de julho de 1984. Institui a Lei de Execução Penal. Diário Oficial da União, Brasília, 13 jul. 1984.

. Constituição (1988). Constituição da República Federativa do Brasil, promulgada em 5 de outubro de 1988. Brasília, DF: Centro Gráfico, 1988. Disponível em: <http://www.planalto.gov.br/ccivil_03/constituicao/constituicao.htm.> Acesso em: 06/10/2021.

Lei N. 9.394, de 20 de dezembro de 1996. Estabelece as diretrizes e bases da educação nacional. Disponível em: <http://www.planalto.gov.br/ccivil_03/Leis/L9394.htm>. Acesso em 20/06/2019. 
Diretrizes Curriculares para o curso de Pedagogia. Brasília: MEC, 2005. BRASIL. Conselho Nacional de Educação (CNE). Câmara de Educação Básica (CEB) Resolução no 2, de 19 de maio de 2010. Dispõe sobre as Diretrizes Nacionais para a oferta de educação para jovens e adultos em situação de privação de liberdade nos estabelecimentos penais. Diário Oficial da União, Brasília, DF, Seção 1.

. Conselho Nacional de Política Criminal e Penitenciária (CNPCP). Resolução no 3, de 11 de março de 2009. Dispõe sobre as Diretrizes Nacionais para a Oferta de Educação nos Estabelecimentos penais. Diário Oficial da União, Brasília, Seção 1, p. 22, 25 mar. 2009.

. Conselho Nacional de Educação (CNE). Câmara de Educação Básica (CEB). Resolução no 2, de 19 de maio de 2010. Dispõe sobre as Diretrizes Nacionais para a oferta de educação para jovens e adultos em situação de privação de liberdade nos estabelecimentos penais. Diário Oficial da União, Brasília, DF, Seção 1, p. 20, 20 maio 2010.

Diretrizes Curriculares Nacionais para a Educação Profissional Técnica de Nível Médio em Debate. Texto para discussão. Brasília, 2010. Disponível em: $<$ http://portal.mec.gov.br/index.php?option=com_docman\&view=download\&alias=10221consultaeaudenciapublicas-dcn-2012\&category_slug=marco-2012pdf\&Itemid=30192>． Acesso: $14 / 02 / 2021$

. Lei $n^{\circ} 12.433$, de 29 de junho de 2011. Altera a Lei no 7.210, de 11 de julho de 1984 (Lei de Execução Penal), para dispor sobre a remição de parte do tempo de execução da pena por estudo ou por trabalho. Diário Oficial da União, Brasília, 30 de junho de 2011.

BOITEUX, Luciana. A reforma da Política Internacional de Drogas virá de baixo para cima. Argumentum, Vitória (ES), v. 7, n.1, pp. 17-20, jan./jun. 2015.

BOUTINET, Jean-Pierre. Antropologia do projeto. 5. ed. Porto Alegre: Artes Médicas, 2002.

CARVAlHO, Luiz Francisco Filho. A Prisão. São Paulo: Publifolha. 2002.

CERTEAU, Michel de. A escrita da História. Tradução de Maria de Lourdes Menezes; revisão de Arno Vogel. 2 ed. Rio de Janeiro: Forense Universitária, 2008. 
COMPARATO, Fábio Konder. A afirmação histórica dos direitos humanos. 6. ed. São Paulo: Saraiva, 2008, p.01

CONFERÊNCIA INTERNACIONAL DE EDUCAÇÃO DE ADULTOS (Confintea), 6., 2010, Belém, Brasil. Marco de ação de Belém. Brasília: Unesco, 2010. Disponível em: <http://www.unesco.org/fileadmin/MULTIMEDIA/INSTITUTES/UIL/confintea>. Acesso em 20/06/2019.

CONTI, José Mauricio. Solução para a crise carcerária tem significativo reflexo orçamentário. In: CONTI, José Mauricio. Levando o Direito Financeiro a sério. São Paulo: Blucher, pp. 75-80, 2018.

CORAZZA, Sandra Mara. Infância e educação. Era uma vez... quer que conte outra vez? Petrópolis: Vozes, 2002.

COSTA, Antonio Carlos Gomes. Fundamentos teóricos e metodológicos da Pedagogia social no Brasil. In: I Congresso Internacional de Pedagogia Social, 1., 2006, Anais eletrônicos. Faculdade de Educação, Universidade de São Paulo, Disponível em: <http://www.proceedings.scielo.br> Acesso em: 09/09/2018.

COYLE, Andrew. Administração Penitenciária: uma abordagem de direitos humanos. Manual para servidores penitenciários. (Edição Brasileira) Londres: Internacional Centre for Prison Studies, 2002.

DEPEN - Departamento Penitenciário Nacional/Ministério da Justiça. Modelo de Gestão para política prisional. Infopen. Brasília: DEPEN, 2016. Disponível em: <https://www.justica.gov.br/modelo-de-gestao_documento-final. Acesso em 05/04/2021>

DÍAZ, Andrés Soriano. Uma aproximação à pedagogia: educação social. Revista Lusófona de Educação. v. 7, n. 7, pp. 91-104, 2006.

DUDLEY, Steven; BARGENT, James. The prison dilemma of organized crime. Insight Crime. Disponível em: <https://www.insightcrime.org/investigations/prison-dilemma-latin-americaincubators-organized-crime/> . Acesso em 20/06/2019.

FAUSTO, Boris. Crime e cotidiano: a criminalidade em São Paulo, 1880 - 1924. São Paulo: Ed. Edusp, $2^{\mathrm{a}}$ ed, 2001.

FOCAULT, Michel. Vigiar e punir. Ed. 41. Editora Vozes. Rio de Janeiro, 2013. 
FRANCO, Maria Amelia do Rosario Santoro. Dinâmica compreensiva: integrando identidade e formação docente. X ENDIPE. 2000, Rio de Janeiro. Anais. Rio de Janeiro: DP\&A, 2000.

FREIRE, Moema Dutra. Paradigmas de segurança no Brasil: da ditadura aos nossos dias. Revista Brasileira de Segurança Pública, Ano 3, edição 5, pp. 100-114, ago./set. 2009.

FREIRE, Paulo. A mensagem de Paulo Freire: textos de Paulo Freire selecionados pelo INODEP. São Paulo, Nova Crítica, 1977.

. Ação cultural para a liberdade e outros escritos. 5. ed. Rio de Janeiro: Paz e Terra, 1981.

. Educação como prática da liberdade. Paz e Terra: Rio de Janeiro, 1983.

Pedagogia do oprimido. 17. ed. Rio de Janeiro: Paz e Terra, 1987.

. A Educação na Cidade. São Paulo: Cortez; 1991.

. Professora sim, tia não: cartas a quem ousa ensinar. São Paulo: Olho d'Água, 1997.

Pedagogia da anatomia: Saberes necessários à prática educativa. Rio de Janeiro: Paz e Terra, 1999.

GADAMER, Hans-Georg. Verdade e Método. Trad. De Flávio P. Meurer; Revisão de Trad. De Enio Paulo Giachini. 13. Ed. - Petrópolis, RJ: Vozes. Bragança Paulista; Editora Universitária São Francisco, 2013.

GADOTTI, Moacir. Pressupostos do projeto pedagógico. In: MEC Conferência nacional de educação para todos. Anais Brasília, 1994.

GARLAND, David. A cultura do controle: crime e ordem social na sociedade contemporânea. Tradução: André Nascimento. Rio de Janeiro: Revan, 2005.

GOFFMAN, Irving. Manicômios, prisões e conventos. São Paulo: Perspectiva, 1987.

GOMES, Fábio Guedes. Conflito social e welfare state: Estado e desenvolvimento social no Brasil. Revista de Administração Pública, volume 40, edição 2. São Paulo, 2006. 
GOMES, Alexandre Tavessoni. O fundamento de validade do direito: Kant e Kelson. Belo Horizonte: Mandamentos, 2000.

HOBSBAWM, Eric. Era dos extremos: o breve século XX (1914-1991). São Paulo: Companhia das Letras, 1995.

HOLLOWAY, John. Fissurar o Capitalismo. São Paulo: Publisher, 2013.

IRELAND, Timothy. Educação em prisões no Brasil: direito, contradições e desafios. Em Aberto, Brasília, v. 24, n. 86, p. 19-39, nov. 2011.

IZAR, Juliana Gama. O projeto pedagógico em instituições de acolhimento para crianças e adolescentes. In: Proceedings of the 4th. Congresso Internacional de Pedagogia Social. IV Congresso Internacional de Pedagogia Social, 2012, São Paulo (SP, Brazil) [online]. 2012

JULIÃO, Elionaldo Fernandes. Escola na ou da prisão? In: Cad. Cedes, Campinas, v. 36, n. 98, p. 25-42, jan.-abr., 2016

KANT, Immanuel. Sobre um Suposto Direito de Mentir por Amor à. Humanidade :In:Os filósofos e a mentira (Fernando Rey Puente, org.). Belo Horizonte, Editora UFMG; Departamento de Filosofia - FAFICH/UFMG, 2002.

KOENER, Andrei. O impossível panóptico tropical-escravista: práticas prisionais, política e sociedade no brasil do século XIX. Revista Brasileira de Ciências Criminais. vol. 35. 2001.

KOSIK, Karel. Dialética do concreto. Rio de Janeiro: Paz e Terra, 1976.

LENINE, Vladimir. O Imperialismo: Fase Superior do Capitalismo. Germinal: Marxismo e Educação em Debate, Salvador, v. 4, n. 1, jun. 2012.

LENOIR, Yves. Didática e interdisciplinaridade: uma complementaridade necessária e incontornável. In: FAZENDA, Ivani Catarina Arantes. Didática e interdisciplinaridade. Campinas: Papirus, p. 45$75,1998$.

LIBÂNEO José Carlos; OLIVEIRA João Ferreira, TOSCHI Mirza Seabra. Educação Escolar: políticas, estrutura e organização. $7^{\text {a }}$ ed. São Paulo: Cortez, 2009. 
LIRA, Vanessa Freitas de. ARAÚJO, Edinaura. Concepções sobre a educação de Jovens e Adultos no sistema prisional na cidade de Cajazeiras-PB: Enfoques na economia solidária. Universidade Federal de Campina Grande (UFCG), 2014. Disponível em: <http://iuees.ufcg.edu.br/wpcontent/uploads/2014/06/Vanessa-Freitas-De-LiraConcep\%C3\%A7\%C3\%B5es-Sobre-A-

Educa\%C3\%A7\%C3\%A3o-De-Jovens-E-AdultosNo-Sistema-Prisional-Na-Cidade-De-CajazeirasPb-Enfoques-Na-EconomiaSolid\%C3\%A1ria.pdf> Acesso em 20/06/2019.

MACHADO, Evelcy Monteiro. Pedagogia Social: educação não formal. In: Pedagogia em Debate, Curitiba. Anais. v. 1. Universidade Tuiuti do Paraná, 2002. Disponível em: <http://www.boaaula.com.br/iolanda/producao/mestradoemeducacao/pubonlineevelcy17>. Acesso em 20/06/2019.

MATEUS, Maria do Nascimento Esteves. O educador social na construção de pontes socioeducativas contextualizadas. Instituto Politécnico de Bragança, Escola Superior de Educação. 2012. Disponível em: <https://bibliotecadigital.ipb.pt/bitstream/10198/7726/1/87-335-1-PB.pdf> Acesso em 20/06/2019.

MAYER, Marc De. A educação na prisão não é uma mera atividade. Educação \& Realidade, Porto Alegre, v.38, n.1, p.33-49, jan./mar. 2013.

Aprender e desaprender. In: UNESCO. Educando para a liberdade: trajetória, debates e proposições de um projeto para a educação nas prisões brasileiras. Brasília: Unesco, Governo japonês, Ministério da Educação, Ministério da Justiça, p. 43-57, 2006 . Disponível em: <http://unesdoc.unesco.org/_images/0014/001495/149515por.pdf>. Acesso em: 22/01/2020

Na prisão existe a perspectiva da educação ao longo da vida? Alfabetização e Cidadania. Revista de Educação de Jovens e Adultos, n. 19, Brasília, 2006.

MINGARDI, Guaraci. Política de segurança: os desafios de uma reforma. São Paulo: Perseu Abramo, 2013.

MIRABETE, Julio Fabbrini. Execução penal: comentários à Lei no $7210,8^{\mathrm{a}}$ ed. Atlas, São Paulo, 1984. 
MOREIRA, Fabio Aparecido. Educação prisional: gênese, desafios e nuances do nascimento de uma política pública de educação. 2016. 75 f. Tese (Doutorado) - Universidade de São Paulo, Faculdade de Educação. São Paulo, 2016.

OLIVEIRA, Carolina Bessa F. A educação nas prisões brasileiras: a responsabilidade da universidade pública. 2017. 293 f. Tese (Doutorado). Faculdade de Educação da Universidade de São Paulo. São Paulo, 2017.

OLSEN, Ana Carolina Lopes. Direitos fundamentais sociais: efetividade frente à reserva do possível. Curitiba: Juruá, 2008.

ONOFRE, Elenice Maria Cammarosano; JULIÃO, Elionaldo Fernandes. A educação na prisão como política pública: entre desafios e tarefas. Educação \& Realidade. Porto Alegre, vol.38 no.1, pp. 5169, 2013.

. Educação escolar para jovens e adultos em situação de privação de liberdade. In: Cad. Cedes, Campinas, v. 35 , n. 96, p. 239-255, maio-ago., 2015. Disponível em: <http://www.scielo.br/pdf/ccedes/v35n96/1678-7110-ccedes-35-96-00239.pdf.> Acesso em 20/06/2019.

PIMENTA, Victor. Conter o poder punitivo: alternativas ao encarceramento em massa. Carta Maior, 2015. Disponível em: <http://cartamaior.com.br/?/Editoria/PrincipiosFundamentais/Contero-poder-punitivo-alternativas-ao-encarceramento-emmassa/40/3387>1. Acesso em 12/03/2020

PINI, Francisca Rodrigues de Oliveira. Fóruns DCA: Fios que tecem o Movimento da Infância e daAdolescência na construção de caminhos para a democraciaparticipativa. 2006. 266 f. Tese (Doutorado em Serviço Social). Pontifícia Universidade Católica de São Paulo, São Paulo 2006.

PORTUGUÊS, Manoel Rodrigues. Educação de adultos presos: possibilidade e contradições da inserção da educação escolar nos programas de reabilitação do sistema penal do estado de São Paulo. 2001. 208 f. Dissertação (mestrado). Universidade de São Paulo, Faculdade de Educação. São Paulo, 2001. 
QUEIROZ, Cristina. O princípio da não reversibilidade dos direitos fundamentais sociais: princípios dogmáticos e prática jurisprudencial. Coimbra: Coimbra Editora, 2006.

RUSCHE, Jesus Robson. Educação de adultos presos: uma proposta metodológica. São Paulo: Funap, 1995.

SADER, Emir. Contexto histórico e educação em direitos humanos. In: SILVEIRA, Rosa Maria Godoy et al. Educação em direitos humanos: fundamentos teórico-metodológicos. João Pessoa: Ed. Universitária, 2007.

SALLA, Fernando. Vigiar e Punir e os Estudos Prisionais no Brasil. Dilemas: Revista de Estudos de Conflito e Controle Social, Edição Especial, n.2, pp.29-43, 2017.

SANTOS, Adairson Alves dos. O Estado Democrático de Direito. Âmbito Jurídico, Rio Grande, XIV, n. 91, ago 2011. Disponível em: http:<//www.ambito-juridico.com.br/site/ > Acesso em 20/06/2019.

SANTOS, Cristiane Farias Rodrigues. Políticas públicas e o Poder Judiciário: segurança pública e administração penitenciária. In CONTI, José Mauricio. Poder Judiciário: políticas públicas. Vol. II. São Paulo: Almedina, pp. 537-577. 2018.

SOUSA SANTOS, Boaventura. Construindo as Epistemologias do Sul: Antologia Essencial. Volume I: Para um pensamento alternativo de alternativas. Compilado por Maria Paula Meneses. [et al.]. 1 ed. Ciudad Autónoma de Buenos Aires: CLACSO, 2018.

SÃO PAULO. Deliberação CEE 155/17. Dispõe sobre avaliação de alunos da Educação Básica, nos níveis fundamental e médio, no Sistema Estadual de Ensino de São Paulo e dá providências correlatas. Disponível em: <http://www.escoladeformacao.sp.gov.br/portais/Portals/84/docs/cursosconcursos/ingresso/supervisordeensino/Anexo\%20E22_DELIBERA\%C3\%87\%C3\%83O\%20CEE $\% 2015517>$. Acesso 23/03/2021.

PARECER CEE no 67/98. Normas Regimentais Básicas para as Escolas Estaduais. CEF/CEM. 1998 . Disponível em: < http://siau.edunet.sp.gov.br/ItemLise/arquivos/notas/parcee67_98.htm. Acesso em 24/08/2020>. Acesso 23/03/2021. 
. Resolução Conjunta SE-SAP-2, de 30-12-2016. Dispõe sobre a oferta da educação básica a jovens e adultos que se encontram em situação de privação de liberdade no Sistema Prisional do Estado de São Paulo, e dá providências correlatas. Disponível em: <http://siau.edunet.sp.gov.br/ItemLise/arquivos/RESOLU\%C3\%87\%C3\%83O\%20CONJUNTA\%2 OSE\%20-SAP-2,\%20DE\%2030-12-2016.HTM?Time=06/01/2017\%2020:23:17> Acesso em 20/06/2019.

SAVIANI, Demerval. Educação: do senso comum à consciência filosófica. 8 ed. São Paulo, Cortez, 1980.

Pedagogia Histórico-Crítica: primeiras aproximações. 9. ed. Campinas: Autores Associados, 2005.

SHIROMA, Eneida Oto. MORAES Maria Célia Marcondes de; EVANGELISTA, Olinda. Política educacional. $4^{\mathrm{a} e d}$. Rio de Janeiro: Lamparina, 2007.

SILVA, Maria Abádia. Qualidade social da educação pública: algumas aproximações. Cad. CEDES. vol.29 no.78 Campinas May/Aug. 2009.

SILVA, Roberto. Didática no Cárcere II. São Paulo: Ed. Giostri, 2018.

SILVA, Roberto da; MARQUES, Marineila Aparecida. Os modelos de oferta da educação em prisões no Brasil e a construção do seu projeto político pedagógico. Plurais Revista Multidisciplinar, 6(1), 49-67, 2021.

SILVA, Roberto da; MOREIRA, Fábio Aparecido. Objetivos educacionais e objetivos da reabilitação penal: o diálogo possível. Revista Sociologia Jurídica, n. 3, jul./dez. 2006.

. O projeto político-pedagógico para a educação em prisões. Em Aberto, INEP, v. 24, n. 86, pp. 1-11. 2011. Disponível em: 〈http://emaberto.inep.gov.br/index.php/emaberto/article/view/2317> Acesso em 20/06/2019.

SILVA, Roberto da; MOREIRA, Fábio Aparecido de; OLIVEIRA, Carolina Bessa Ferreira de. Ciências, trabalho e educação no sistema penitenciário brasileiro. Cad. CEDES [online], vol.36, n.98, pp.9-24, 2016. 
SILVA, Roberto da; SOUZA NETO João Clemente de; MOURA, Rogério. Pedagogia Social. São Paulo: Expressão \& Arte, 2009.

SOUZA NETO, Jorge Fernando de. ARAUJO, José Jefferson Oliveira de. A privatização da prisão brasileira: um processo de reprodução e valorização do capital. Anais do I Congresso Internacional de Direito Público dos Direitos Humanos e Políticas de Igualdade. UFAL, Alagoas, v. 1, n. 1, 2018.

SUNSTEIN, Cass Robert. The Second Bill of Rights: FDR's Unfinished Revolution and Why we Need it More than Ever. Nova York: Basic Books, 2004.

SZABÓ, Ilona; RISSO, Melina. Segurança pública para virar o jogo. Rio de Janeiro: Zahar, 2018.

TEIXEIRA, José Carlos Pinheiro. O papel da Educação como programa de reinserção social para jovens e adultos privados de liberdade: perspectivas e avanços. Boletim 06, EJA e Educação Prisional. Salto para o Futuro - TV Escola. Brasília, SEED-MEC, pp.14-21, 2007.

THOMPSON, Augusto Frederico Gaffrée. A Questão Penitenciária. Petrópolis, RJ, Vozes, 1976.

UNESCO. Educando para a liberdade: trajetória, debates e proposições de um projeto para a educação nas prisões brasileiras. Governo japonês, Ministério da Educação, Ministério da Justiça, Brasília, 2006.

VASCONCELLOS, Celso dos Santos. Coordenação do trabalho pedagógico: do projeto político pedagógico ao cotidiano da sala de aula. São Paulo: Libertad Editora, 2009.

VASQUEZ, Eliane Leal. Sociedade cativa. Entre cultura escolar e cultura prisional: uma incursão pela ciência penitenciária. Rio de Janeiro: CBJE, 2010.

- Ciência penitenciária no Brasil império: disciplinar para construir a imagem da nação civilizada. 2013. 130 f. Tese (Doutorado em História da Ciência). Pontifícia Universidade Católica de São Paulo, São Paulo, 2013. 
VEIGA, Ilma Passos Alencastro. Projeto político-pedagógico da Escola: uma construção coletiva, In: Projeto político-pedagógico da Escola: uma construção possível. $7^{a}$ ed., Ed. Papirus, Campinas: SP, 1998.

WACQUANT, Loïc. Punir os pobres. A nova gestão da miséria nos Estados Unidos. Rio de Janeiro: Revan, 2003.

ZALUAR, Alba. A máquina e a revolta. São Paulo: Editora Brasiliense, 1985. 